\title{
AVALIAÇÃO DA HIPERESTESIA DENTINÁRIA APÓS TRATAMENTO COM DIFERENTES FORMULAÇÕES À BASE DE OXALATO DE POTÁSSIO UTILIZANDO-SE UM PLACEBO COMO CONTROLE.
}

\section{ANA CHRISTINA BONATO FIGUEIREDO MARTINELI}

Dissertação apresentada à Faculdade de Odontologia de Bauru, da Universidade de São Paulo, como parte dos requisitos para obtenção do título de Mestre em Odontologia - Área de concentração: Dentística.

BAURU

1999 


\section{AVALIAÇÃO DA HIPERESTESIA DENTINÁRIA APÓS TRATAMENTO COM DIFERENTES FORMULAÇÕES À BASE DE OXALATO DE POTÁSSIO, UTILIZANDO-SE UM PLACEBO COMO CONTROLE.}

\section{ANA CHRISTINA BONATO FIGUEIREDO MARTINELI}

Dissertação apresentada à Faculdade de Odontologia de Bauru, da Universidade de São Paulo, como parte dos requisitos para obtenção do título de Mestre em Odontologia - Área de concentração: Dentística.

(Edição Revista)

Orientador:

Prof. Dr. JOSÉ CARLOS PEREIRA 

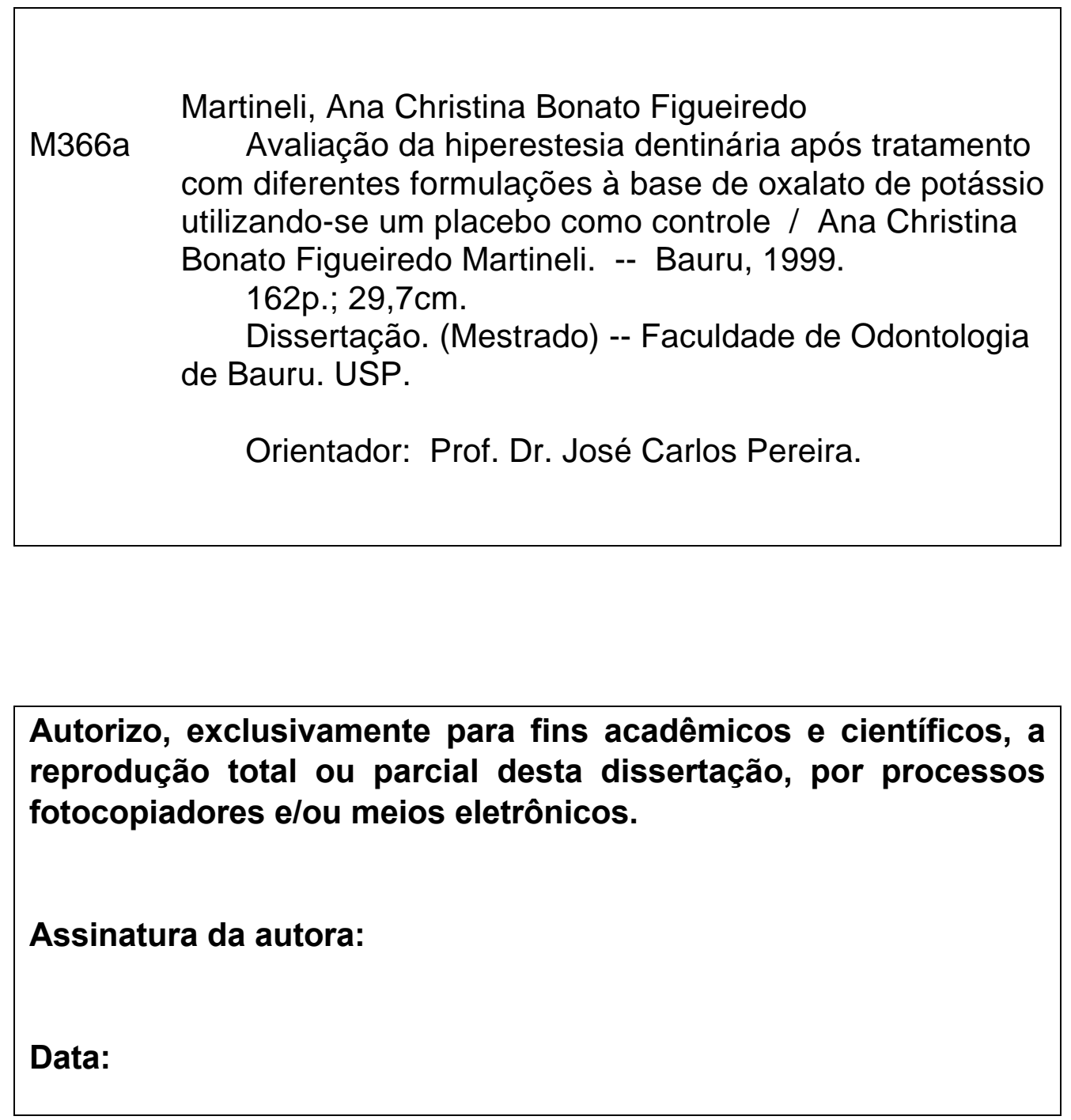


\section{ANA CHRISTINA BONATO FIGUEIREDO MARTINELI}

23 de dezembro de 1969

Marília - SP

$1988-1991$

1994

1997

$1997-1999$

ASSOCIAÇÕES
Nascimento

Curso de Odontologia - Faculdade de Odontologia da Universidade de Marília - SP.

Curso de Especialização em Dentística, na Faculdade de Odontologia de Bauru - Universidade de São Paulo.

Professora auxiliar do Departamento de Clínica Integrada da Faculdade de Odontologia da Universidade de Marília - SP.

Professora auxiliar do Departamento de Dentística da Faculdade de Odontologia da Universidade de Marília - SP.

Curso de Pós-Graduação em Dentística, em nível de Mestrado, na Faculdade de Odontologia de Bauru USP.

* Associação Paulista de Cirurgiões Dentistas (APCD)- Regional de Marília.

* APG - Associação Pós-graduandos da FOB-USP

* Sociedade Brasileira de Pesquisas Odontológicas (SBPqO)

* International Association for Dental Research (IADR) 
Dedico este trabalho

Aos meus pais Raul e Arlete,

queria aqui agradecer por tudo, tudo que envolve tanto,

tanto que vocês por mim fizeram.

Fizeram não só porque são pais, mas porque são pais muito especiais.

Especiais na maneira que educam, educam para formar.

Formaram um alicerce tão forte, tão forte e seguro.

Seguro sim, porque quando acredito, acredito e luto, luto e venço, venço e agradeço, agradeço porque amo, amo não só porque sou filha, mas porque sou filha que se sente muito amada, muito amada e agradecida.

De sua filha,

Ana Christina 


\section{A Deus,}

pela minha existência e por fazer dela um caminho iluminado.

\section{Ao meu esposo Dorival,}

meu grande amor, companheiro e amigo, por todo apoio, estímulo e compreensão nesta etapa de nossas vidas.

Aos meus pais Raul e Arlete,

por minha formação, pelo exemplo de garra, coragem e honestidade, pelo amor e dedicação, ensinando-me a acreditar e a lutar por um ideal.

\section{Ao meu querido irmão Raul,}

por todo incentivo, o apoio sem medidas e pelo exemplo de questionar sempre e nunca contemplar o horizonte como limite.

Aos meus avós Aurélio (in memoriam) e Antônia Maria,

por terem gerado uma família tão unida e pelos exemplos de trabalho, honestidade e humildade. 
Ao Prof. Dr. José Carlos Pereira,

pelo exemplo de educador e pesquisador, pelo incentivo, orientação, dedicação e competência, por depositar em mim confiança, por contribuir grandemente para meu crescimento pessoal e profissional, gostaria de registrar aqui toda minha admiração e respeito.

Muito obrigada, sempre. 
Agradeço também,

Aos meus colegas do curso de Mestrado, em especial à Juliana, Mônica, Sérgio, Rodrigo e Juliano, com os quais exercitei a verdadeira amizade e compartilhei valiosos momentos.

A todos os pacientes que participaram desta pesquisa.

Ao Prof. Dr. José Roberto Pereira Lauris pela realização da análise estatística deste trabalho.

A todos os professores e funcionários do Departamento de Dentística da Faculdade de Odontologia de Bauru - USP.

Às funcionárias da Clínica de Pós-graduação da Faculdade de Odontologia de Bauru, Ana e Cleusa, por estarem sempre prontas a ajudar.

Aos funcionários da secretaria de Pós-graduação da Faculdade de Odontologia de Bauru Neide, Heloísa, Giane, Aurélio e Débora, que sempre me atenderam com eficiência e cordialidade.

Aos funcionários da Associação de Pós-Graduação e da Biblioteca da Faculdade de Odontologia de Bauru, em especial à Cybelle e Rita.

Ao Diretor da Faculdade de Ciências Odontológicas da Universidade de Marília, Dr. Marco Antônio Sampaio Pelli e ao Prof. Dr. Walter Rino, por todo apoio e incentivo.

Aos meus colegas do Departamento de Dentística da Faculdade de Ciências Odontológicas da Universidade de Marília, Luís Anselmo, Roque, Lúcia Helena, Silmar, Fábio, Taylane; e ainda Faria e Renata, por todo apoio.

À CAPES pela concessão da Bolsa.

A todos que tornaram possível a conclusão deste trabalho.

Muito obrigada. 


\section{SUMÁRIO}

\section{LISTA DE TABELAS}

\section{RESUMO}

\section{INTRODUÇÃO}

2 REVISÃO DA LITERATURA 6

2.1. Terminologia e Definição 7

2.2. Incidência e Prevalência 9

2.3. Etiologia e Fatores Predisponentes 11

2.4. Diagnóstico Diferencial 13

2.5. Mecanismos da Hiperestesia 15

2.6 Formas de Tratamento 20

2.6.1. Ação Anti-inflamatória 24

2.6.2. Despolarização das Terminações Nervosas (Ação Neural) 25

2.6.3. Obliteração dos Túbulos Dentinários 26

2.7. Efeito Placebo 28

2.8. Estudos Laboratoriais 30

2.9 Avaliação Clínica 37

2.9.1 Mensuração da Dor Associada à Hiperestesia Dentinária 38

2.9.1.1. Estímulos 38

2.9.1.2. Quantificação da Resposta - Escalas de Medida 41

2.9.2. Estudos de Avaliação Clínica 43

3 PROPOSIÇÃO

4 MATERIAL E MÉTODO 59

$\begin{array}{lll}4.1 & \text { MATERIAL } & 60\end{array}$

4.1.1. Seleção dos Pacientes $\quad 60$

4.1.2. Seleção dos Dentes 63 
4.1.3. Instrumentos e Materiais 65

4.2 MÉTODO 66

4.2.1. Determinação dos Padrões de Hiperestesia 67

$\begin{array}{ll}\text { 4.2.2. Grupos Experimentais } & 67\end{array}$

5 RESULTADOS 75

6 DISCUSSÃO 103

6.1 Considerações Gerais 104

6.2 Discussão da Metodologia 105

6.3 Discussão dos Resultados 118

7 CONCLUSÕES 127

REFERÊNCIAS BIBLIOGRÁFICAS

$\begin{array}{ll}\text { ABSTRACT } & 143\end{array}$

$\begin{array}{ll}\text { APÊNDICE } & 146\end{array}$ 


\section{LISTA DE TABELAS}

TABELA 5.1 - Variação da sensibilidade dentinária no Grupo 1 (Oxa-Gel $\left.{ }^{\circledR}\right)$ utilizando-se a sonda como estímulo, comparando-se os resultados obtidos antes e depois da primeira aplicação.

TABELA 5.2 - Variação da sensibilidade dentinária no Grupo 1 (Oxa-Gel ${ }^{\circledR}$ ) utilizando-se a sonda como estímulo, comparando-se os resultados obtidos antes da primeira aplicação e depois da segunda aplicação.

TABELA 5.3 - Variação da sensibilidade dentinária no Grupo 1 (Oxa-Gel $\left.{ }^{\circledR}\right)$ utilizando-se a sonda como estímulo, comparando-se os resultados obtidos antes da primeira aplicação e depois da terceira aplicação.

TABELA 5.4 - Variação da sensibilidade dentinária no Grupo 1 (Oxa-Gel $\left.{ }^{\circledR}\right)$ utilizando-se a sonda como estímulo, comparando-se os resultados obtidos antes da primeira aplicação e depois da quarta aplicação.

TABELA 5.5 - Variação da sensibilidade dentinária no Grupo 1 (Oxa-Gel ${ }^{\circledR}$ ) utilizando-se a sonda como estímulo, comparando-se os resultados obtidos antes da primeira aplicação e depois de 06 meses.

TABELA 5.6 - Variação da sensibilidade dentinária no Grupo 1 (Oxa-Gel $\left.{ }^{\circledR}\right)$ utilizando-se a sonda como estímulo, comparando-se os resultados obtidos depois da quarta aplicação e depois de 6 meses.

TABELA 5.7 - Variação da sensibilidade dentinária no Grupo 1 (Oxa-Gel $\left.{ }^{\circledR}\right)$ utilizando-se o ar como estímulo, comparando-se os resultados obtidos antes da primeira e depois da quarta aplicação.

TABELA 5.8 - Variação da sensibilidade dentinária no Grupo 1 (Oxa-Gel $\left.{ }^{\circledR}\right)$ utilizando-se o ar como estímulo, comparando-se os resultados obtidos antes da primeira aplicação e depois de 06 meses.

TABELA 5.9 - Variação da sensibilidade dentinária no Grupo 1 (Oxa-Gel $\left.{ }^{\circledR}\right)$ utilizando-se o ar como estímulo, comparando-se os resultados obtidos depois da quarta aplicação e depois de 06 meses.

TABELA 5.10 - Variação da sensibilidade dentinária no Grupo 2 (Solução Experimental 1) utilizando-se a sonda como estímulo, comparando-se os resultados obtidos antes da primeira aplicação e depois da quarta aplicação.

TABELA 5.11 - Variação da sensibilidade dentinária no Grupo 2 (Solução Experimental 1) utilizando-se a sonda como estímulo, comparando-se os resultados obtidos antes da primeira aplicação e depois de 06 meses. 
TABELA 5.12 - Variação da sensibilidade dentinária no Grupo 2 (Solução Experimental 1) utilizando-se a sonda como estímulo, comparando-se os resultados obtidos depois da quarta aplicação e depois de 06 meses.

TABELA 5.13 - Variação da sensibilidade dentinária no Grupo 2 (Solução Experimental 1) utilizando-se o ar como estímulo, comparando-se os resultados obtidos antes da primeira aplicação e depois da quarta aplicação.

TABELA 5.14 - Variação da sensibilidade dentinária no Grupo 2 (Solução Experimental 1) utilizando-se $o$ ar como estímulo, comparando-se os resultados obtidos antes da primeira aplicação e depois de 06 meses.

TABELA 5.15 - Variação da sensibilidade dentinária no Grupo 2 (Solução Experimental 1) utilizando-se $o$ ar como estímulo, comparando-se os resultados obtidos depois da quarta aplicação e depois de 06 meses.

TABELA 5.16 - Variação da sensibilidade dentinária no Grupo 3 (Solução Experimental 2) utilizando-se a sonda como estímulo, comparando-se os resultados obtidos antes da primeira aplicação e depois da quarta aplicação.

TABELA 5.17 - Variação da sensibilidade dentinária no Grupo 3 (Solução Experimental 2) utilizando-se a sonda como estímulo, comparando-se os resultados obtidos antes da primeira aplicação e depois de 06 meses.

TABELA 5.18 - Variação da sensibilidade dentinária no Grupo 3 (Solução Experimental 2) utilizando-se a sonda como estímulo, comparando-se os resultados obtidos depois da quarta aplicação e depois de 06 meses.

TABELA 5.19 - Variação da sensibilidade dentinária no Grupo 3 (Solução Experimental 2) utilizando-se o ar como estímulo, comparando-se os resultados obtidos antes da primeira aplicação e depois da quarta aplicação.

TABELA 5.20 - Variação da sensibilidade dentinária no Grupo 3 (Solução Experimental 2) utilizando-se $o$ ar como estímulo, comparando-se os resultados obtidos antes da primeiras aplicação e depois de 06 meses.

TABELA 5.21 - Variação da sensibilidade dentinária no Grupo 3 (Solução Experimental 2) utilizando-se o ar como estímulo, comparando-se os resultados obtidos depois da quarta aplicação e depois de 06 meses.

TABELA 5.22 - Variação da sensibilidade dentinária no Grupo 4 (Placebo) utilizando-se a sonda como estímulo, comparando-se os resultados obtidos antes da primeira aplicação e depois da quarta aplicação. 
TABELA 5.23 - Variação da sensibilidade dentinária no Grupo 4 (Placebo) utilizando-se a sonda como estímulo, comparando-se os resultados obtidos antes da primeira aplicação e depois de 06 meses.

TABELA 5.24 - Variação da sensibilidade dentinária no Grupo 4 (Placebo) utilizando-se a sonda como estímulo, comparando-se os resultados obtidos depois da quarta aplicação e depois de 06 meses.

TABELA 5.25 - Variação da sensibilidade dentinária no Grupo 4 (Placebo) utilizando-se o ar como estímulo, comparando-se os resultados obtidos antes da primeira aplicação e depois da quarta aplicação.

TABELA 5.26 - Variação da sensibilidade dentinária no Grupo 4 (Placebo) utilizando-se o ar como estímulo, comparando-se os resultados obtidos antes da primeira aplicação e depois de 06 meses.

TABELA 5.27 - Variação da sensibilidade dentinária no Grupo 4 (Placebo) utilizando-se o ar como estímulo, comparando-se os resultados obtidos depois da quarta aplicação e depois de 06 meses.

TABELA 5.28A: - Escores médios dos resultados Imediato e Mediato para os diferentes grupos e estímulos (Teste de Friedman two way ANOVA).

TABELA 5.28B:- Teste de Kruskal-Wallis para comparação dos resultados entre os quatro grupos.

\section{APÊNDICE}

TABELA 29 - Variação da sensibilidade dentinária no Grupo $1\left(\right.$ Oxa-Gel $\left.{ }^{\circledR}\right)$ utilizando-se $\mathrm{o}$ ar como estímulo, comparando-se os resultados obtidos antes e depois da primeira aplicação.

TABELA 30 - Variação da sensibilidade dentinária no Grupo 1 (Oxa-Gel $\left.{ }^{\circledR}\right)$ utilizando-se o ar como estímulo, comparando-se os resultados obtidos antes da primeira aplicação e depois da segunda aplicação.

TABELA 31 - Variação da sensibilidade dentinária no Grupo $1\left(\right.$ Oxa-Gel $\left.{ }^{\circledR}\right)$ utilizando-se $o$ ar como estímulo, comparando-se os resultados obtidos antes da primeira aplicação e depois da terceira aplicação.

TABELA 32 - Variação da sensibilidade dentinária no Grupo 2 (Solução Experimental 1) utilizando-se a sonda como estímulo, comparando-se os resultados obtidos antes e depois da primeira aplicação. 
TABELA 33 - Variação da sensibilidade dentinária no Grupo 2 (Solução Experimental 1) utilizando-se a sonda como estímulo, comparando-se os resultados obtidos antes da primeira aplicação e depois da segunda aplicação.

TABELA 34 - Variação da sensibilidade dentinária no Grupo 2 (Solução Experimental 1) utilizando-se a sonda como estímulo, comparando-se os resultados obtidos antes da primeira aplicação e depois da terceira aplicação.

TABELA 35 - Variação da sensibilidade dentinária no Grupo 2 (Solução Experimental 1) utilizando-se o ar como estímulo, comparando-se os resultados obtidos antes e depois da primeira aplicação.

TABELA 36 - Variação da sensibilidade dentinária no Grupo 2 (Solução Experimental 1) utilizando-se 0 ar como estímulo, comparando-se os resultados obtidos antes da primeira aplicação e depois da segunda aplicação.

TABELA 37 - Variação da sensibilidade dentinária no Grupo 2 (Solução Experimental 1) utilizando-se $o$ ar como estímulo, comparando-se os resultados obtidos antes da primeira aplicação e depois da terceira aplicação.

TABELA 38 - Variação da sensibilidade dentinária no Grupo 3 (Solução Experimental 2) utilizando-se a sonda como estímulo, comparando-se os resultados obtidos antes e depois da primeira aplicação.

TABELA 39 - Variação da sensibilidade dentinária no Grupo 3 (Solução Experimental 2) utilizando-se a sonda como estímulo, comparando-se os resultados obtidos antes da primeira aplicação e depois da segunda aplicação.

TABELA 40 - Variação da sensibilidade dentinária no Grupo 3 (Solução Experimental 2) utilizando-se a sonda como estímulo, comparando-se os resultados obtidos antes da primeira aplicação e depois da terceira aplicação.

TABELA 41 - Variação da sensibilidade dentinária no Grupo 3 (Solução Experimental 2) utilizando-se o ar como estímulo, comparando-se os resultados obtidos antes e depois da primeira aplicação.

TABELA 42 - Variação da sensibilidade dentinária no Grupo 3 (Solução Experimental 2) utilizando-se 0 ar como estímulo, comparando-se os resultados obtidos antes da primeira aplicação e depois da segunda aplicação.

TABELA 43 - Variação da sensibilidade dentinária no Grupo 3 (Solução Experimental 2) utilizando-se $o$ ar como estímulo, comparando-se os 
resultados obtidos antes da primeira aplicação e depois da terceira aplicação.

TABELA 44 - Variação da sensibilidade dentinária no Grupo 4 (Placebo) utilizando-se a sonda como estímulo, comparando-se os resultados obtidos antes e depois da primeira aplicação.

TABELA 45 - Variação da sensibilidade dentinária no Grupo 4 (Placebo) utilizando-se a sonda como estímulo, comparando-se os resultados obtidos antes da primeira aplicação e depois da segunda aplicação.

TABELA 46 - Variação da sensibilidade dentinária no Grupo 4 (Placebo) utilizando-se a sonda como estímulo, comparando-se os resultados obtidos antes da primeira aplicação e depois da terceira aplicação.

TABELA 47 - Variação da sensibilidade dentinária no Grupo 4 (Placebo) utilizando-se o ar como estímulo, comparando-se os resultados obtidos antes e depois da primeira aplicação.

TABELA 48 - Variação da sensibilidade dentinária no Grupo 4 (Placebo) utilizando-se 0 ar como estímulo, comparando-se os resultados obtidos antes da primeira aplicação e depois da segunda aplicação

TABELA 49 - Variação da sensibilidade dentinária no Grupo 4 (Placebo) utilizando-se $o$ ar como estímulo, comparando-se os resultados obtidos antes da primeira aplicação e depois da terceira aplicação.

TABELA 50 - Variação da sensibilidade dentinária no Grupo 1, independente do estímulo utilizado, comparando-se os resultados obtidos antes da primeira aplicação e depois da quarta aplicação.

TABELA 51 - Variação da sensibilidade dentinária no Grupo 1, independente do estímulo utilizado, comparando-se os resultados obtidos depois da quarta aplicação e depois de 06 meses.

TABELA 52 - Variação da sensibilidade dentinária no Grupo 2, independente do estímulo utilizado, comparando-se os resultados obtidos antes da primeira aplicação e depois da quarta aplicação.

TABELA 53 - Variação da sensibilidade dentinária no Grupo 2, independente do estímulo utilizado, comparando-se os resultados obtidos depois da quarta aplicação e depois de 06 meses.

TABELA 54 - Variação da sensibilidade dentinária no Grupo 3, independente do estímulo utilizado, comparando-se os resultados obtidos antes da primeira aplicação e depois da quarta aplicação.

TABELA 55 - Variação da sensibilidade dentinária no Grupo 3, independente do estímulo utilizado, comparando-se os resultados obtidos 
depois da quarta aplicação e depois de 06 meses.

TABELA 56 - Variação da sensibilidade dentinária no Grupo 4, independente do estímulo utilizado, comparando-se os resultados obtidos antes da primeira aplicação e depois da quarta aplicação.

TABELA 57 - Variação da sensibilidade dentinária no Grupo 4, independente do estímulo utilizado, comparando-se os resultados obtidos depois da quarta aplicação e depois de 06 meses. 


\section{AVALIAÇÃO DA HIPERESTESIA DENTINÁRIA APÓS TRATAMENTO COM DIFERENTES FORMULAÇÕES À BASE DE OXALATO DE POTÁSSIO, UTILIZANDO-SE UM PLACEBO COMO CONTROLE.}

A hiperestesia dentinária é uma das mais antigas queixas de desconforto dos pacientes e, devido à sua alta incidência e diversidade de tratamentos sugeridos na literatura, novos produtos devem ser avaliados quanto ao efeito e aplicabilidade. O propósito deste estudo foi avaliar as respostas imediata e mediata de 94 dentes (caninos e pré-molares), que apresentavam algum grau de sensibilidade dentinária (1, 2 ou 3 ) de acordo com a Escala de Medida Verbal (EMV) aos estímulos sonda e ar, após a aplicação de três formulações à base de oxalato de potássio: Oxa-Gel ${ }^{\circledR}$, Solução Experimental 1 e Solução Experimental 2, tendo um placebo como controle. Cada formulação de oxalato de potássio e o placebo foram aplicados passivamente por 3 minutos na superfície da dentina úmida, sendo o excesso de material removido posteriormente. O grau de sensibilidade foi avaliado antes (baseline) e imediatamente após a aplicação de cada formulação com um intervalo de 7 dias. Os resultados obtidos após a quarta aplicação foram denominados resultados imediatos e, após 6 meses, resultados mediatos. Os escores foram submetidos à análise estatística através dos testes de Kruskal-Wallis e de Friedman two-way ANOVA $(p<0,05)$. A aplicação de todos os materiais, inclusive o placebo, independente do tempo avaliado e dos estímulos utilizados, resultou em uma redução estatisticamente significante na hiperestesia dentinária podendo essa redução prolongar-se até seis meses. Houve uma 
tendência de respostas mais severas ao estímulo ar quando comparado ao estímulo sonda antes do tratamento, sendo que a hiperestesia provocada pela sonda se mostrou mais persistente ao longo do tratamento. $\mathrm{O}$ tratamento da hiperestesia dentinária está sujeito a variáveis clínicas que podem aumentar ou diminuir o efeito anti-hiperestésico dos agentes estudados. 
1 INTRODUÇÃO 


\section{INTRODUÇÃO}

Vários são os termos para denominar a manifestação sensorial da dentina, porém, não há uma terminologia universalmente aceita que a defina corretamente ${ }^{62}$. O termo sugerido e adotado no presente trabalho é "hiperestesia dentinária", para caracterizar a sensação dolorosa da dentina a um determinado estímulo que não seja a cárie dental ${ }^{77}$.

A maioria dos autores ${ }^{82,62,11}$ define hiperestesia dentinária como sendo uma resposta exagerada ou uma dor passageira relacionada à exposição da dentina a estímulos químicos, tácteis, térmicos ou osmóticos provenientes do meio bucal, os quais, normalmente, não causariam resposta em um dente saudável. Essa exposição pode ser resultante de perda de esmalte por processos de abfração, erosão ou abrasão e, também, por desnudamento da superfície radicular por recessão gengival ou tratamento periodontal. A dor é conseqüência da exposição dentinária e sua intensidade varia nos diferentes dentes e entre as pessoas, estando, ainda, diretamente relacionada ao grau de tolerância à dor, bem como aos fatores emocionais de cada paciente ${ }^{83}$.

A hiperestesia dentinária é uma das mais antigas queixas de pacientes ${ }^{20}$ e um problema constante na clínica odontológica, pois afeta um número cada vez maior de pessoas incomodadas com essa condição desconfortável ${ }^{30}$. O fato de que, atualmente, existe uma conscientização maior da importância da saúde dos dentes e, como conseqüência, a manutenção mais prolongada dos mesmos na cavidade bucal, a dentina pode tornar-se, então, mais susceptível à exposição de fatores 
externos, causando o aumento de casos de sensibilidade ou hiperestesia dentinária $25,91$.

Estudos demonstram que a hiperestesia dentinária afeta entre 10 a $20 \%$ da população, sendo a prevalência similar em várias partes do mundo, embora apresente algumas diferenças regionais. A hiperestesia dentinária pode ocorrer em qualquer dente; a maioria dos estudos, porém, aponta caninos e pré-molares como os mais comuns, ocorrendo quase que invariavelmente na face vestibular ${ }^{62}$.

Quando o paciente relata hiperestesia dentinária, o dentista deve considerar um número variado de possíveis causas antes de formular um plano de tratamento, pois muitas são as situações clínicas que podem ser confundidas com a hiperestesia dentinária $^{97,7}$. Um diagnóstico cuidadoso, por meio de anamnese e exames clínico e radiográfico, portanto, é necessário para descartar outras causas da dor ${ }^{7,77,30}$.

Dentre as várias teorias que tentam explicar o mecanismo da hiperestesia dentinária, a Teoria da Hidrodinâmica é a mais aceita. Esta teoria, proposta por GYSI $^{37}$, em 1900, e solidificada por BRÄNNSTRÖM ${ }^{10}$, em 1966, parte do princípio de que o movimento do fluido no interior dos túbulos dentinários conduz à sensibilidade, em decorrência da ativação sensorial de fibras nervosas presentes na polpa ${ }^{10,24}$.

A dor aguda provocada pela dentina exposta desencadeou a busca de alternativas para seu alívio. Inúmeros estudos que compõem a literatura pertinente apresentam várias formas de tratamento, o que leva à suposição de que nenhuma, ainda, provou ser totalmente eficiente ${ }^{77,30}$. Algumas vezes, pode ocorrer a dessensibilização através de um tipo de reação natural à agressão, quando a dentina se torna capaz de aumentar seu grau de mineralização, mas, na maioria dos casos, um tratamento é necessário ${ }^{23}$. Entre as formas de tratamento indicadas, inclui-se o 
uso de agentes e terapias que atuam de modos diferentes, seja por ação antiinflamatória, por despolarização das terminações nervosas, ou por efeito oclusivo dos canalículos dentinários.

GROSSMAN $^{36}$, em 1935, recomenda que o material ou agente antihiperestésico ideal deve ter as seguintes características: não ser irritante à polpa, permitir fácil aplicação, ser indolor, ter ação rápida e efeito prolongado e não promover o manchamento dos dentes.

Conforme se mencionou anteriormente, a teoria mais aceita para explicar o mecanismo da hiperestesia dentinária é a Teoria da Hidrodinâmica. Assim, os agentes que interagem com o mecanismo hidráulico da dentina, atuando sobre a condutibilidade da mesma são os mais utilizados. O objetivo clínico do tratamento da hiperestesia dentinária é promover o selamento dos túbulos dentinários. Os agentes que obliteram os canalículos dentinários podem atuar através da precipitação de proteínas, pela deposição de cristais nos túbulos dentinários ou por técnicas restauradoras convencionais. Os índices de sucesso e falha de agentes ou técnicas variam entre os pesquisadores ${ }^{14}$

Segundo $\mathrm{COX}^{19}$, em 1994, um selamento efetivo pode ser conseguido pela aplicação tópica de oxalatos que, sob a forma de precipitados insolúveis, penetrariam no interior dos túbulos dentinários, reduzindo, assim, o fluxo do fluido. Alguns estudos clínicos ${ }^{39,18,41,76,24}$ têm relatado, também, uma diminuição da sensibilidade dentinária com o uso de placebos, ou seja, soluções inertes utilizadas como controle para determinar a eficácia das substâncias avaliadas.

O mecanismo da dor dentinária ainda não é bem compreendido, e os sinais e sintomas da hiperestesia são inespecíficos e subjetivos. Por outro lado, uma grande 
variedade de produtos têm sido testados, mas os resultados de sua aplicação são, na maioria das vezes contraditórios. Além disso, é preciso considerar o "efeito placebo", freqüentemente reconhecido como muito significativo nas investigações clínicas $^{23}$. À vista dessas considerações, pode-se dizer que o tratamento da hiperestesia dentinária ainda requer novos estudos e é nesse sentido que o desenvolvimento do presente trabalho busca oferecer uma contribuição. 
2 REVISÃO DE LITERATURA 


\section{REVISÃO DA LITERATURA}

\subsection{TERMINOLOGIA E DEFINIÇÃO}

Os termos utilizados na literatura para designar a manifestação sensorial da dentina exposta são de natureza bastante contraditória ${ }^{68}$ e, por isso, até o presente momento, não há uma terminologia universalmente aceita ${ }^{62}$. A maioria dos autores utiliza "hipersensibilidade dentinária ou dental ", ou apenas "sensibilidade dentinária ou dental" ${ }^{21}$. A palavra "dental" neste caso, refere-se a todo o órgão dental, e não especificamente a uma manifestação que é própria da dentina. Os termos "sensibilidade dentinária" e "hipersensibilidade dentinária" são freqüentemente utilizados. A sensibilidade dentinária é uma resposta normal à dentina exposta, ao passo que a "hipersensibilidade dentinária" pode significar uma sensibilidade excessiva a alguma substância, uma reação imunológica do organismo". Segundo ADDY; WEST", em 1994, o termo "hipersensibilidade dentinária" parece ser o mais apropriado, porque tem sido usado como termo clínico ao longo do tempo e identifica uma condição dental diferenciada.

O termo sugerido por PEREIRA ${ }^{77}$ e adotado nesta dissertação é "hiperestesia dentinária", para traduzir a sensação dolorosa da dentina a um determinado estímulo que não a cárie dental.

Segundo DOWELL; ADDY ${ }^{21}$, em 1983, a hiperestesia dentinária está associada à exposição da superfície radicular do dente a estímulos externos à cavidade bucal. A resposta a estes estímulos pode variar de um simples 
desconforto à dor extrema, podendo interferir no ato da respiração, alimentação ${ }^{102} \mathrm{e}$, ainda, na escovação, prejudicando a higienização e favorecendo o acúmulo de placa bacteriana.

De acordo com TARBET ${ }^{95}$ et al., em 1980, a hiperestesia dentinária está associada à exposição da superfície radicular como resultado de recessão gengival ou como conseqüência de algum tipo de tratamento periodontal. É caracterizada por uma sensação dolorosa desencadeada por estímulos térmicos, químicos e tácteis.

BISSADA $^{7}$, em 1994, define a hiperestesia dentinária como uma resposta exagerada a estímulos sensoriais, que normalmente não causam resposta em um dente saudável, e está relacionada à exposição da dentina ao meio bucal. Essa exposição pode ser resultante de perda de esmalte por processos de erosão e abrasão, ou por desnudamento da superfície radicular por recessão gengival ou tratamento periodontal.

De acordo com ORCHARDSON et al. ${ }^{62}$, em 1994, a hiperestesia dentinária é caracterizada por uma dor transitória em resposta a estímulos tácteis, térmicos ou químico-osmóticos da dentina exposta em dentes onde não há evidência de outro defeito ou patologia.

A Associação Internacional de Estudos da Dor define hiperestesia dentinária como uma dor proveniente da dentina exposta frente a estímulos químicos, térmicos, tácteis e não provenientes de outra causa ou defeito dental. Essa dor é sempre provocada, nunca espontânea ${ }^{6}$. 


\subsection{INCIDÊNCIA E PREVALÊNCIA}

ORCHARDSON; COLLINS ${ }^{63}$, em 1987, avaliaram 109 pacientes e 514 lesões hiperestésicas, sendo $25 \%$ em caninos e $38 \%$ em pré-molares, invariavelmente $(93,0 \%)$ presentes na face vestibular, não tendo influência quanto à idade e sexo do paciente.

COLLAERT; FISCHER ${ }^{16}$, em 1991, em estudo de revisão sobre hiperestesia dentinária, afirmam que os caninos e pré-molares são os dentes mais comuns a apresentarem recessão e hiperestesia dentinária, e que estas estão presentes principalmente na face vestibular.

FISCHER; FISCHER; WENNBERG ${ }^{26}$, em 1992, avaliaram 635 pacientes da Clínica de Odontologia da Marinha do Rio de Janeiro, Brasil. Os pacientes foram examinados através de questionário e de testes intra-orais usando-se sonda clínica e jato de ar. Apesar de 25\% (157) dos pacientes terem reportado sensibilidade, apenas $17 \%$ (108) dos casos foram diagnosticados como hiperestesia dentinária. A maior prevalência foi entre as mulheres, embora a diferença não tenha sido estatisticamente significante. Os dentes que apresentaram a maior prevalência foram os incisivos e os pré-molares, enquanto que os molares mostraram os menores índices.

De acordo com ORCHARDSON et al..$^{62}$, em 1994, a hiperestesia dentinária afeta entre 10 a $20 \%$ da população, sendo a prevalência similar nas várias partes do mundo, embora apresente algumas diferenças regionais. 
AZEVEDO $^{5}$, em 1994, avaliou a ocorrência de lesões dentárias cervicais não cariosas e de hiperestesia dentinária e relatou que a incidência de lesões cervicais não cariosas foi ligeiramente maior no sexo masculino, enquanto que a incidência de hiperestesia dentinária foi semelhante para ambos os sexos. Em relação aos dentes, a maior prevalência, tanto de lesões cervicais não cariosas quanto de hiperestesia, ocorreu nos pré-molares, seguidos dos molares, caninos e incisivos, sendo mais comuns na face vestibular dos dentes da arcada superior.

SOBRAL; CARVALHO; GARONE NETTO ${ }^{93}$, em 1995, em um estudo clínico da prevalência de hiperestesia dentinária, avaliaram 267 pacientes. Os resultados demonstraram que 1 em cada 6 pacientes em tratamento apresentava algum dente com sensibilidade. $\mathrm{O}$ adulto jovem foi mais predisposto, não havendo diferença quanto ao sexo do paciente, sendo, porém, mais comum na face vestibular dos dentes pré-molares.

CHABANSKI et al. ${ }^{13}$, em 1996, realizaram um estudo clínico da prevalência de hiperestesia cervical em pacientes tratados periodontalmente e concluíram que esta prevalência é muito alta (84,0\%), não existindo diferença estatística significante quanto ao sexo. Entretanto, reportaram que a hiperestesia dentinária é mais comum em pacientes com idade entre 40-49 anos. Esse estudo sugere que, por existir uma alta prevalência de hiperestesia em pacientes tratados periodontalmente ou com doenças periodontais, pode-se incluir esta condição como agente etiológico da hiperestesia. 


\subsection{ETIOLOGIA E FATORES PREDISPONENTES}

A hiperestesia dentinária é uma condição dolorosa comum, cuja etiologia e fatores predisponentes ainda precisam ser investigados. O conhecimento dos fatores responsáveis pela exposição da dentina e pela abertura dos túbulos é limitado, embora seja essencial para o tratamento da hiperestesia dentinária ${ }^{3}$. A exposição da dentina cervical tem uma etiologia multifatorial, e a dor pode ser associada a vários estímulos ${ }^{21}$.

O dente torna-se hipersensível quando há exposição de dentina devido à perda do esmalte ou cemento, seus naturais protetores, por várias causas ${ }^{90}$; e a hiperestesia dentinária está associada à exposição das superfícies radiculares dos dentes aos fatores externos da cavidade bucal ${ }^{21}$. Essencialmente, a exposição da dentina é resultante de processos como a remoção do esmalte que recobre a coroa dental ou o desnudamento da superfície radicular pela perda do cemento ou por recessão dos tecidos periodontais ${ }^{21}$. Entretanto, $10 \%$ dos dentes não apresentam cemento recobrindo a porção cervical da raiz e, nesses casos, somente uma retração ou recessão gengival pode causar a hiperestesia dentinária ${ }^{97}$.

De acordo com KANAPKA; COLUSSI ${ }^{45}$, em 1986, a remoção do esmalte que recobre o dente pode ocorrer por processos diversos que incluem abrasão e erosão, ou por desnudamento da superfície radicular como resultado de recessão gengival ou de procedimentos periodontais. Quando a dentina exposta entra em contato com estímulos tácteis, térmicos ou químicos, a sensação de dor pode se manifestar. Segundo PEREIRA ${ }^{77}$, em 1995 e GARONE FILHO ${ }^{30}$, em 1996, a remoção do 
esmalte pode ser decorrente de processos como abrasão, erosão, abfração ou pela combinação desses fatores.

A abrasão pode ser definida como o desgaste mecânico da estrutura dental pela constante fricção efetuada por um corpo estranho ${ }^{63}$. Uma escovação exagerada no sentido horizontal em combinação com dentifrícios abrasivos, com pressão de escovação intensa, escova dental dura, freqüência de escovação quando já existe uma exposição radicular ou, ainda, a raspagem e curetagem radiculares durante o tratamento periodontal podem provocar o desgaste cervical. Segundo SOBRAL ${ }^{91}$, em 1997, ocorre um aumento da porcentagem de dentes com exposição radicular conforme a idade avança e, conseqüentemente, aumenta a quantidade de áreas abrasionadas sensíveis. Esse tipo de lesão é caracterizada por uma superfície lisa, polida, rasa, com contorno regular e localizada na face vestibular.

Quando a perda de substância dentária ocorre devido à dissolução por ácidos não bacterianos provenientes de alimentos (frutas cítricas), bebidas (alguns refrigerantes e vinhos), medicamentos e, ainda, por ácidos provenientes do próprio organismo, como o ácido clorídrico (quando ocorre regurgitação em pacientes com anorexia nervosa ou bulimia), a lesão é denominada erosão. Esse processo pode ser agravado ainda pela xerostomia e pela diminuição da capacidade tampão da saliva, fenômeno conhecido como perimólise ${ }^{85}$. Este tipo de lesão é geralmente generalizado, visto que todos os dentes estão sujeitos aos fatores etiológicos.

A lesão denominada abfração ou atrição é proveniente de forças oclusais excêntricas ou exageradas, que resultam em microfraturas do esmalte por tensões de tração e compressão (teoria da flexão do dente). Como conseqüência , ocorre a 
ruptura dos cristais do esmalte, o que torna a região mais susceptível à abrasão e erosão. As lesões de abfração apresentam-se em forma de cunha, são profundas e tem margens definidas, podendo ser encontradas em apenas um dente.

A etiologia do desnudamento radicular pode estar relacionada a muitos fatores como a recessão gengival, que aumenta com o avanço da idade, doenças periodontais crônicas, algumas cirurgias periodontais, escovação incorreta e traumas crônicos resultantes de hábitos ${ }^{21}$. BISSADA ${ }^{7}$, em 1994, relatou que a hiperestesia causada por tratamentos periodontais é geralmente passageira, enquanto que a associada à erosão e abrasão cervical é mais persistente e mais difícil de se controlar.

Segundo KRAUSER ${ }^{52}$, em 1986, uma hiperestesia severa pode resultar freqüentemente em mudanças emocionais que alteram o estilo de vida diário do paciente.

\subsection{DIAGNÓSTICO DIFERENCIAL}

A definição de hiperestesia dentinária corresponde a uma descrição clínica e requer um diagnóstico diferencial. Muitas condições dentais apresentam sintomas idênticos ou similares e exigem diversos tratamentos, podendo, ainda, ocorrer uma dupla patologia ${ }^{3}$.

Quando o paciente relata hiperestesia dentinária, o dentista deve considerar um número variado de possíveis causas antes de formular um plano de tratamento. Um diagnóstico cuidadoso, portanto, é necessário para descartar outras causas da 
dor. Esse diagnóstico inclui anamnese e exames clínico e radiográfico completos $^{7,77,30}$. Deve-se obter o máximo de informações durante a anamnese, questionando sobre a duração, freqüência e localização da dor, ou seja, os sinais e sintomas do desconforto ${ }^{77}$. Durante o exame clínico, o teste empregando uma sonda exploradora, ou seja, um estímulo táctil, parece ser o mais simples, preciso e rápido no diagnóstico da hiperestesia ${ }^{92}$.

Com a finalidade de determinar a causa do desconforto, os dentes devem ser examinados quanto à presença de lesões cariosas, restaurações, fraturas, descolorações, doenças periodontais, trauma oclusal e propriamente de dentina exposta ${ }^{97}$.

Vários autores ${ }^{22,97,7}$ relatam que existem muitas situações clínicas que podem ser confundidas com a hiperestesia dentinária, como a síndrome do dente trincado, restaurações fraturadas, dentes lascados, sulcos gengivo-palatais, cárie dental, sensibilidade pós-operatória, hipoplasia de esmalte, abertura congênita da junção cemento-esmalte, restaurações metálicas impropriamente cimentadas e dentes em hiperfunção.

No caso de dentes trincados ou não fraturados por completo, o sintoma é dor à pressão. Para um melhor diagnóstico, pode se utilizar o azul de metileno para evidenciar a linha de fratura. Restaurações fraturadas nem sempre são fáceis de diagnosticar, mas, um exame clínico cuidadoso pode levar ao diagnóstico correto ${ }^{97}$. A diferenciação da hiperestesia dentinária e das lesões de cárie é relativamente fácil, principalmente nos caso de lesões de cáries profundas, podendo encontrar-se as duas situações, ou seja, cárie e hiperestesia dentinária no mesmo dente ${ }^{22}$. 
Restaurações recentes podem causar sensibilidade pós-operatória, principalmente frente a estímulos térmicos, sendo essa dor geralmente moderada e de curta duração. Quando o ajuste oclusal não é corretamente realizado, as restaurações ou coroas podem apresentar problemas de contato prematuro, expondo o dente à hiperfunção e causando sintomas semelhantes aos da hiperestesia ${ }^{97}$.

A dor proveniente da dentina exposta a estímulos químicos, térmicos, tácteis ou osmóticos varia em freqüência e severidade ${ }^{52}$. Embora muitos indivíduos apresentem dentina exposta, nem todos têm sintomatologia dolorosa ${ }^{22}$.

Para a maioria dos pacientes, a dor é de curta duração e cessa quase que imediatamente após a remoção do estímulo. Para outros pacientes, porém, a dor é mais intensa e persiste por alguns segundos após a remoção do estímulo. Em ambos os casos, o diagnóstico é dificultado, porque os sintomas não são diferentes daqueles reportados nos casos de cárie e de alterações pulpares. Entretanto, na ausência de outra patologia dental, quando esses sintomas são provenientes da dentina exposta ao meio bucal, o termo hiperestesia dentinária é utilizado para determinar tal condição ${ }^{22}$.

\subsection{MECANISMOS DA HIPERESTESIA}

THOMAS $^{96}$, em 1985, num estudo de revisão sobre a biologia pulpar e dentinária, relata que o complexo dentina/pré-dentina, como todo tecido conjuntivo, é caracterizado pela presença de células e de uma matriz extra-celular. A dentina representa a porção mineralizada dessa matriz extra-celular, enquanto a pré- 
dentina, que não é mineralizada, separa o componente mineralizado dos odontoblastos, as células responsáveis pela formação do tecido.

A característica mais importante da dentina é a presença de túbulos dentinários, os quais se estendem perifericamente desde a junção odontoblasto/prédentina por toda a espessura desse tecido. A permeabilidade dentinária é uma conseqüência direta da presença de túbulos. O número de túbulos dentinários varia de 45 a 65000/mm² na região próxima à polpa, de 29,5 a 35000/mm² na região mediana e de 15 a 20000/mm² próximo ao limite amelodentinário, com diâmetros de $2,5 u m, 1,2 u m$ e $0,9 u m$, respectivamente ${ }^{29}$. Essa aparente diminuição no número de túbulos está relacionada com o aumento da área de superfície de dentina em direção à junção amelodentinária. O túbulo dentinário é composto por dentina peritubular, processo odontoblástico, colágeno, nervos e fluido dentinário, componentes que influenciam de algum modo a permeabilidade dentinária.

O complexo dentino-pulpar tem abundante suprimento nervoso ${ }^{52,8}$, sendo a dentina um tecido altamente sensitivo e com um comportamento diferente quando comparado a outros tecidos do corpo. Na dentina, todo e qualquer estímulo como preparo cavitário, alterações de temperatura, soluções hipertônicas ou desidratação, causam a mesma sensação de dor. A pele, por exemplo, apresenta terminações que distinguem diferentes estímulos como calor, frio, toque ou dor ${ }^{52,30}$.

O mecanismo exato, através do qual o estímulo é transmitido da superfície dentinária para a polpa, não é claro; assim, várias teorias têm sido propostas ${ }^{22}$.

Segundo KRAUSER ${ }^{53}$, em 1986, e DOWELL; ADDY ${ }^{21}$, em 1993 seriam: 
1. os odontoblastos e seus prolongamentos atuam como receptores dentinários, participando na iniciação e na transmissão de um estímulo.

2. os nervos da polpa, e não da dentina, são os receptores da dor, sendo estimulados pelo mecanismo hidrodinâmico.

Com relação à primeira proposta, alguns autores como FRANK ${ }^{27}$, em 1968, COLLAERT; FISCHER ${ }^{16}$, em 1991, afirmam que não existe sinapse entre os odontoblastos e os nervos pulpares, e os prolongamentos odontoblásticos não se estendem além de um terço à metade do comprimento dos túbulos dentinários. Desse modo, apesar de evidências de que a dentina possui terminações nervosas, não existe uma explicação clara de como um estímulo aplicado à dentina pode influenciar fibras nervosas que, aparentemente, não penetram em toda a extensão dos túbulos dentinários ou de maneira uniforme na dentina ${ }^{86}$.

Dentre as várias teorias que tentam explicar o mecanismo da hiperestesia dentinária, a Teoria da Hidrodinâmica, baseada em uma suposta ausência de fibras nervosas $^{51}$, parece ser a mais aceita no momento ${ }^{90}$.

Conforme se explicou anteriormente, a dentina apresenta cerca de 30.000 túbulos por $\mathrm{mm}^{2}$, os quais são preenchidos com um material fluido ou semi-fluido, cuja movimentação é impedida pela presença do esmalte, que veda esses túbulos no limite amelo-cementário. Um estímulo de qualquer natureza, como o preparo cavitário, alterações de temperatura (alimentos quentes ou frios), soluções hipertônicas (substâncias doces ou ácidas), desidratação (jato de ar ou respiração), pressão (ponta do explorador), pode determinar uma variação da pressão intrapulpar 
por movimentação do fluido dentinário em direção à polpa ou em sentido contrário, dependendo da natureza do estímulo. Assim, através das terminações nervosas próximas à camada odontoblástica, ocorre a transmissão dessa sensação até a polpa. Se o esmalte da região cervical é perdido por erosão ou abrasão e na presença de recessão gengival, ocorre a exposição da dentina ao meio bucal e, conseqüentemente, dos túbulos dentinários. Isso permite a movimentação do fluido nos túbulos dentinários, a qual, por gerar uma pressão positiva ou negativa conforme a sua direção, provoca a dor ${ }^{68}$.

O movimento dos fluidos no interior dos túbulos dentinários foi, primeiramente, reportado por $\mathrm{GYSI}^{37}$, em 1900. BRÄNNSTRÖM ${ }^{10}$, em 1966, procurando uma explicação alternativa para a sensibilidade da dentina e partindo do princípio de que não existem fibras nervosas na mesma, reintroduziu o conceito de GYSI $^{37}$ sobre a Teoria da Hidrodinâmica. Segundo essa teoria, alguns estímulos provocam rápido movimento do fluido dentinário (2 a $4 \mathrm{~mm} / \mathrm{seg}^{52}$ ) nos túbulos ${ }^{22} \mathrm{e}$ esse movimento ativa as terminações nervosas responsáveis pela dor na interface dentina-polpa ${ }^{102}$.

BRÄNNSTRÖM; ASTRÖM ${ }^{9}$, em 1972, afirmaram que experimentos in vivo e in vitro em dentes humanos têm dado suporte à hipótese de que a hidrodinâmica é responsável pela transmissão do estímulo da dor da superfície dentinária para as terminações nervosas no complexo dentino-pulpar e/ou polpa. Eles concluem que o movimento do conteúdo tubular na porção pulpar para fora dos túbulos é o mais responsável pelo aparecimento da dor do que o deslocamento na direção oposta. A diferença da resposta hidrodinâmica ao frio, ar e calor parece corresponder a 
diferenças observadas clinicamente na característica da dor. Os autores concluem, então, que há dois tipos de dor nos dentes, possivelmente mediadas por dois tipos de nervos.

Com base na Teoria da Hidrodinâmica, seria lógico concluir que o dentes com hiperestesia dentinária deveriam apresentar túbulos dentinários abertos na superfície dentinária e desobstruídos até a polpa. ABSI; ADDY, ADAMS ${ }^{1}$, em 1987, avaliaram in vitro a abertura dos túbulos dentinários na dentina cervical sensível e não sensível e observaram que, comparando-se dentes não sensíveis com dentes hiperestésicos, existe um aumento significativo no número de túbulos por área de aproximadamente 8 vezes nos dentes hiperestésicos. Observaram, ainda, que, nesses dentes com sensibilidade, os túbulos apresentaram-se significativamente mais amplos. Segundo RIMONDINI; BARONI; CARASSI ${ }^{81}$, em 1995, a dentina hiperestésica apresenta uma smear layer mais fina, diferente em estrutura e provavelmente menos calcificada que a dentina não sensível. Além disso, os túbulos dentinários parecem ser mais numerosos e amplos. Essas características dão suporte à teoria do aumento da permeabilidade hidrodinâmica da dentina hiperestésica.

PASHLEY ${ }^{65}$, em 1992, numa revisão de literatura sobre permeabilidade e sensibilidade dentinária, afirmou que a teoria da hidrodinâmica é baseada na premissa de que a dentina sensível é permeável em toda a extensão dos túbulos. Essa condição permite a difusão de produtos bacterianos pela dentina até alcançar a polpa, causando irritação dos tecidos pulpares. Entretanto, a movimentação do fluido dentinário para fora é lenta e tende a deixar que substâncias exógenas 
passem pelos túbulos abertos. O autor conclui que o equilíbrio entre a difusão de substâncias exógenas, sejam estas de origem bacteriana ou agentes dessensibilizantes, e a limpeza proporcionada pelo fluido merecem mais estudo. Acrescenta, ainda, que qualquer tratamento que reduza a permeabilidade dentinária deverá diminuir a sensibilidade. Esse entendimento do papel da permeabilidade dentinária no processo de hipersensibilidade faz com que métodos simples de estudo in vitro examinem o potencial de novos agentes terapêuticos na oclusão dos túbulos.

\subsection{FORMAS DE TRATAMENTO}

A utilização do ópio para tratamento da hiperestesia dentinária data de 400 a.C. até meados de 1000 d.C., quando se passou a usar uma grande variedade de tratamentos, como a utilização de plantas negras e insetos triturados, estendendose essa prática até o início de 1800. Em 1859, como formas de tratamento, introduziram-se a cocaína, bem como o creosoto, ácido tânico e o arsênico, os quais foram utilizados até o final do século passado. Por volta de 1920, surgiram como nova opção as soluções aquosas compostas de iodo e nitrato de prata. O iodeto de prata surgiu posteriormente e mostrou-se eficaz no alívio da hiperestesia dentinária, com a vantagem de não escurecer o dente como o nitrato de prata. A utilização de vitaminas A e D solúveis foi baseada na teoria nutricional da hiperestesia dentinária. Já no anos 50, eram utilizados óleo de oliva quente, formaldeído, nitrato de prata, cloreto de zinco, carbonato de cálcio e fluoreto de 
sódio. Muitos desses materiais tinham ação entorpecente, alguns estimulavam a formação de dentina secundária, e outros eram adesivos e cobriam as áreas sensíveis $^{53}$.

A remissão espontânea da hiperestesia, ou seja, o processo de dessensibilização natural, embora lento, é uma proteção natural e pode ocorrer devido a processos fisiológicos, como a remineralização pela saliva, por formação de dentina secundária e terciária ${ }^{53,66}$ e, ainda, pela formação de smear layer através da escovação, procedimentos periodontais e preparo cavitário ${ }^{102}$. ORCHARDSON et al. $^{62}$, em 1994, afirmam que a hiperestesia resultante de tratamento periodontal cessa após 3 ou 4 semanas como resultado da oclusão dos túbulos dentinários. Entretanto, a sensibilidade persiste entre 10 a $15 \%$ destes pacientes. A razão de falha no mecanismo natural em alguns pacientes é desconhecida, mas pode estar relacionada a fatores locais, tais como a composição e o fluxo da saliva.

Existem casos, porém, em que a sintomatologia é permanente e, para estes, muitos são os tratamentos propostos ${ }^{90}$. A literatura apresenta várias formas de tratamento, o que faz crer que nenhuma delas é totalmente eficiente ${ }^{77,30}$. O clínico deve utilizar um tratamento para a hiperestesia que esteja o mais próximo do ideal quanto possível ${ }^{28}$, e o tipo de tratamento deve ser determinado com base na extensão e severidade da lesão ${ }^{22}$.

O tratamento da hiperestesia dentinária apresenta dificuldades que não se relacionam totalmente com aquele indicado pelo profissional, porque não existe um tratamento que possa ser realizado em casa pelo paciente e que seja aceito como adequado para atuar em conjunto com o procedimento realizado no consultório. Um 
tratamento definitivo, permanente ou que elimine os sintomas por um longo período de tempo requer a utilização diária, pelo paciente, de um anti-hiperestésico eficaz ${ }^{95}$. Segundo ADDY; WEST ${ }^{3}$, em 1994 e RICHMOND ${ }^{80}$, em 1993, o tratamento das lesões cervicais não cariosas hiperestésicas baseia-se em duas diferentes abordagens:

1. por bloqueio da transmissão neural pelos nervos pulpares através da alteração da excitabilidade dos nervos sensoriais.

2. por bloqueio do mecanismo hidrodinâmico (movimento do fluido) através da oclusão dos túbulos dentinários utilizando materiais endógenos ou exógenos.

Tal tratamento envolve, ainda, duas categorias ${ }^{80}$ :

a) aqueles aplicados pelo cirurgião-dentista em consultório;

b) aqueles utilizados em casa pelo próprio paciente (delivery systems).

O tratamento por bloqueio dos túbulos é o mais apropriado e tem sido a base teórica de muitas formulações.

KLEINBERG ${ }^{49}$, em 1986, resumiu as diferentes abordagens clínicas que têm sido sugeridas para o tratamento da hiperestesia dentinária:

1. remineralização por deposição de fosfato de cálcio da saliva no interior dos túbulos dentinários;

2. formação de dentina secundária, o que pode ocorrer naturalmente ou através de estímulos, como a escovação diária; 
3. hidróxido de cálcio, que facilita a deposição de fosfato de cálcio proveniente do fluido dentinário e da saliva;

4. formação de oxalato de cálcio pelo oxalato de potássio dentro dos túbulos dentinários;

5. fluoreto de sódio, que promove a deposição de fluorapatita menos solúvel;

6. nitrato de prata, que precipita proteínas no interior dos túbulos dentinários;

7. cloreto de estrôncio, que forma hidroxiapatita de estrôncio e fosfato de estrôncio no interior dos túbulos dentinários;

8. resinas, que selam a embocadura dos túbulos dentináros;

9. nitrato de potássio, que parece ser efetivo;

10. dentifrícios que podem conter um dos ingredientes ativos acima citados ou atuam na oclusão dos túbulos dentinários.

DOWELL; ADDY; DUMMER ${ }^{22}$, em 1985, mostram os agentes mais comumente utilizados no tratamento da hiperestesia dentinária quando essa condição se apresenta localizada ou generalizada:

Quadro 2.1: Métodos e materiais utilizados no tratamento da hiperestesia dentinária.

\begin{tabular}{|c|c|c|c|}
\hline \multicolumn{2}{|c|}{ HIPERESTESIA LOCALIZADA } & \multicolumn{2}{|c|}{ HIPERESTESIA GENERALIZADA } \\
\hline - Aplicação de: & $\begin{array}{l}\text { - Resina } \\
\text { - Adesivo } \\
\text { - Verniz fluoretado }\end{array}$ & - Dentifrícios com: & $\begin{array}{l}\text { - Estrôncio } \\
\text { - Formalina } \\
\text { - Flúor }\end{array}$ \\
\hline - Restauração & & \multirow{2}{*}{\multicolumn{2}{|c|}{$\begin{array}{l}\text { - Soluções para bochechos bucais c/ } \\
\text { diferentes concentrações de Flúor }\end{array}$}} \\
\hline - Endodontia & & & \\
\hline
\end{tabular}


GROSSMANN $^{36}$, em 1935, relacionou algumas características que devem ser consideradas quando se escolhe o agente anti-hiperestésico:

- não ser irritante à polpa;

- ser de fácil aplicação;

- ter ação rápida (alívio imediato);

- promover efeito duradouro;

- não manchar ou descolorir o dente;

- ter efetividade comprovada;

- ser de baixo custo.

Os agentes e terapias anti-hiperestésicas podem ser classificados quanto ao seu modo de ação em ${ }^{77}$ :

1. ação anti-inflamatória;

2. despolarização das terminações nervosas (ação neural);

3. obliteração dos túbulos dentinários.

\subsubsection{AÇÃO ANTI-INFLAMATÓRIA}

O tratamento com drogas anti-inflamatórias (corticosteróides) está indicado para processos pulpares inflamatórios que não estejam relacionados com dor provocada pela exposição da dentina, embora essas drogas, ao reduzirem a pressão intra-pulpar, reduzam a sensibilidade ${ }^{77}$. $O$ efeito anti-inflamatório dos glicocorticóides é bem conhecido, e acredita-se que a aplicação tópica deste em um preparo cavitário e sobre a dentina exposta diminui a sensibilidade da mesma ${ }^{53}$. 


\subsubsection{DESPOLARIZAÇÃO DAS TERMINAÇÕES NERVOSAS (AÇÃO NEURAL)}

Os sais de potássio apresentam-se eficazes no tratamento da hiperestesia dentinária, seja em aplicações tópicas ou em dentifrícios ${ }^{94}$. HODOSH ${ }^{40}$, em 1974 , foi o primeiro a descrever o nitrato de potássio como agente anti-hiperestésico. Esse agente atua por despolarização das membranas das fibras nervosas, bloqueando a passagem do estímulo, e não por obstrução dos túbulos dentinários pela deposição de cristais ou por diminuir a condutibilidade hidráulica da dentina. MARKOWITZ; $\mathrm{KIM}^{55}$, em 1985, realizaram um estudo sobre os efeitos de diferentes soluções iônicas na sensibilidade neural da polpa e concluíram que o citrato de sódio e o ácido nítrico têm pouco efeito sobre a atividade sensorial da polpa, sendo que os íons potássio reduziram essa sensibilidade em $85,4 \%$.

STEAD; ORCHARDSON, WARREN ${ }^{94}$, em 1996, utilizaram um modelo matemático para avaliar o desempenho do íon potássio nos túbulos dentinários. Os resultados sugeriram que a aplicação de soluções contendo potássio na superfície dentinária pode aumentar a concentração de potássio na extremidade interna dos túbulos dentinários a níveis suficientes para inativar terminações nervosas da polpa nos túbulos. Entretanto, o aumento localizado da concentração de potássio é passageiro, e a concentração será diminuída à medida que aumenta a velocidade do fluido dentinário ou a permeabilidade da barreira entre o túbulo e a polpa.

Em outro estudo, realizado por PEACOCK; ORCHARDSON ${ }^{73}$, em 1999, sais orgânicos de potássio foram avaliados quanto à habilidade de bloquear a condução neural, e seus efeitos comparados com cloreto de potássio e nitrato de potássio. As soluções testadas (citrato de potássio, oxalato de potássio e tartarato de potássio) 
foram aplicadas no nervo raquidiano de ratos e o potencial de ação foi monitorado por computador. Os resultados indicaram que todos os sais de potássio atenuaram o potencial de ação, não havendo diferença estatisticamente significante entre as soluções de tartarato de potássio e citrato de potássio, sendo estes mais efetivos que outros sais de potássio no bloqueio da condução neural.

\subsubsection{OBLITERAÇÃO DOS TÚBULOS DENTINÁRIOS}

Como já foi mencionado, a teoria mais aceita para explicar o mecanismo da hiperestesia dentinária é a Teoria da Hidrodinâmica. Um efetivo tratamento para a hiperestesia dentinária seria, portanto, a obliteração dos túbulos dentinários a fim de reduzir ou inibir o movimento dos fluidos nos túbulos ou a permeabilidade dentinária ${ }^{102}$. Desse modo, o objetivo clínico do tratamento da hiperestesia dentinária é promover o selamento permanente dos túbulos dentinários ${ }^{21,19}$ através de agentes que interagem com o mecanismo hidráulico da dentina, influenciando a condutibilidade da mesma.

Os agentes que obliteram os canalículos dentinários podem atuar através da precipitação de proteínas, deposição de cristais nos túbulos dentinários ou de partículas, aplicação de película impermeabilizadora, aplicação de raios laser ou por técnicas restauradoras convencionais ${ }^{14,77}$. Os índices de sucesso e falha de agentes ou técnicas variam entre os pesquisadores ${ }^{14}$.

O seguinte quadro, adaptado de SENA ${ }^{87}$, em 1990, resume os diferentes agentes e terapias anti-hiperestésicas com efeito oclusivo sobre os canalículos dentinários: 
Quadro 2.2: Agentes e procedimentos com efeito oclusivo sobre os canalículos dentinários.

\begin{tabular}{|l|l|}
\hline PROVÁVEL MECANISMO DE AÇÃO & AGENTES OCLUSIVOS \\
\hline Precipitação de Proteínas & - Nitrato de Prata \\
& - Formalina \\
& - Cloreto de Zinco \\
\hline Deposição de Partículas & - Oxalato de Potássio \\
& - Hidróxido de Cálcio \\
& - Compostos Fluoretados \\
& - lontoforese \\
& - Cloreto de Estrôncio \\
& - Brunidura \\
\hline Película Impermeabilizadora & - Vernizes \\
& - Adesivos Dentinários \\
\hline Procedimentos Restauradores & - Sistemas adesivos \\
& - Resinas Compostas \\
\hline & - Cimentos de lonômero de Vidro \\
\hline
\end{tabular}

Em princípio, a obliteração dos túbulos é conseguida pela reação de um sal solúvel com o líquido dos túbulos dentinários, reagindo com íons cálcio e potássio provenientes da dissolução da hidroxiapatita que constitui as paredes dos túbulos dentinários. Essa reação resulta em compostos insolúveis que se precipitam como cristais e obliteram a embocadura dos túbulos, eliminando a hiperestesia dentinária ${ }^{30}$. COOFEY et al. ${ }^{17}$, em 1970 , pesquisaram o fluido dentinário e os resultados revelaram que o fluido é um líquido amarelo claro, quase transparente e, ao microscópio, não apresentou células ou grânulos. Quanto à composição, os autores concluíram que o fluido dentinário contém sódio, potássio e cloro, e 
provavelmente é saturado em íons cálcio e potássio, porém suas concentrações exatas não foram obtidas. As concentrações de sódio e potássio, entretanto, se aproximaram do fluido intersticial, o que levou os autores a concluirem que o fluido dentinário se localiza extracelularmente e não é derivado do citoplasma ou do processo odontoblástico. Pode-se dizer, então, que o oxalato de potássio reage tanto com a dentina quanto com o fluido dentinário.

O oxalato de potássio combina as propriedades de oclusão dos túbulos dentinários com a inibição da atividade neural ${ }^{66,61}$. Segundo GRENHILL, PASHLEY ${ }^{35}$, em 1981, o selamento dos túbulos dentinários pode ser conseguido com a aplicação tópica de oxalatos que formam precipitados insolúveis na embocadura e no interior dos túbulos dentinários, reduzindo o fluxo do fluido e controlando a sensibilidade da dentina exposta. Esse tipo de tratamento tem sido reportado por muitos autores, que têm utilizado o oxalato de potássio em diferentes concentrações.

A hiperestesia dentinária é, talvez, mais uma complexidade de sintomas do que uma doença propriamente dita, e a severidade da dor ou como o paciente a interpreta é que determina qual tratamento deve ser realizado ${ }^{21,22}$.

\subsection{EFEITO PLACEBO}

Alguns estudos clínicos têm relatado uma diminuição da sensibilidade dentinária com o uso de placebos, utilizados como controle para determinar a eficácia de substâncias ativas, e avaliar as mudanças psicológicas, no sistema nervoso ou em ambos, na percepção da hiperestesia ${ }^{19}$. 
Um placebo é uma substância que o paciente acredita ser eficaz, embora não contenha o agente ativo, e o "efeito placebo", um dos fenômenos mais fascinantes na medicina, ocorre quando o paciente melhora após receber esse tratamento ${ }^{98,99}$.

A hiperestesia dentinária é, segundo WICHGERS; EMERT ${ }^{102}$, em 1996, um assunto complexo devido aos fatores psicológicos e à natureza subjetiva da dor, pois trata-se de uma dor crônica com períodos de agudização e, como tal envolve componentes psicológico.

Segundo TURNER ${ }^{99}$, em 1999, o fator emocional do paciente tem grande importância, e a resposta ao placebo em determinada situação não significa que o paciente irá responder favoravelmente a essa mesma substância uma situação diferente. $\mathrm{O}$ "efeito placebo" provavelmente resulta na redução do estresse e da ansiedade do paciente, que podem afetar o corpo e intensificar sintomas individuais. Se o paciente acredita que o tratamento vai melhorar sua condição, isso pode diminuir sua ansiedade, preocupação e, conseqüentemente, os sintomas.

Outros aspectos considerados para explicar o efeito placebo estão relacionados com a influência do clínico e com a personalidade, expectativa e condescendência do paciente. De acordo com TROWBRIDGE; SILVER ${ }^{97}$, em 1990, e TURNER, em $1999^{99}$, o maior fator de resposta ao placebo é a qualidade da relação entre o paciente e o profissional. Quando o profissional demonstra amizade, interesse, simpatia pelo paciente e positividade em relação ao tratamento, ele pode motivar o paciente a obter alívio. Em outras palavras, se o profissional afirma que o tratamento será eficaz, provavelmente o será. 
O "efeito placebo" é, então, decorrente de interações fisiológicas e psicológicas, sendo o relacionamento entre o paciente e o profissional o principal fator de resposta positiva ao placebo. Além disso, um comportamento emocional positivo e motivado pode ativar o sistema central de inibição da dor do organismo, o qual controla o estímulo doloroso da periferia através da liberação de endorfinas pelo sistema nervoso central ${ }^{97}$.

\subsection{ESTUDOS LABORATORIAIS}

Muitos são os estudos laboratoriais que comprovam a eficácia do oxalato de potássio no alívio da hiperestesia dentinária.

GREENHILL; PASHLEY ${ }^{35}$, em 1981, avaliaram in vitro a capacidade de os agentes empregados como desensibilizantes dentinários atuarem na redução da movimentação do fluido pela dentina. O oxalato de potássio a $30 \%$ obteve o melhor resultado, alcançando níveis de $98,4 \%$ na redução da permeabilidade dentinária. Isso pode ser devido ao fato de que os cristais de oxalato de cálcio formados mostraram-se de tamanho semelhante ao diâmetro dos túbulos dentinários, penetrando no interior dos mesmos.

PASHLEY et al. ${ }^{67}$, em 1984, avaliaram in vitro o efeito de diferentes dentifrícios dessensibilizantes na condutância hidráulica da dentina. Os dentifrícios comerciais utilizados foram Thermodent, Sensodyne, Promise, Denquel e Crest; sendo avaliado ainda um dentifrício experimental contendo oxalato de potássio a 
2\%. Para cada dentifrício comercial, menos para o Thermodent, foi utilizado um dentifrício placebo idêntico aos demais, exceto pela ausência do ingrediente ativo. $O$ dentifrício experimental contendo oxalato como componente ativo foi claramente superior aos demais $(95,0 \%)$, produzindo uma redução imediata na sensibilidade dentinária. Não houve diferença estatisticamente significante entre os demais dentifrícios e os placebos, o que pode ser atribuído ao fato de que algumas partículas abrasivas contidas nestes dentifrícios poderiam ser pequenas o suficiente para penetrar no interior dos túbulos dentinários.

PASHLEY; GALLOWAY ${ }^{69}$, em 1985, avaliaram o efeito do oxalato de potássio em superfícies de dentina com o objetivo de descobrir como o mesmo reage com a smear layer, se atua reduzindo sua permeabilidade ou aumentando sua resistência ao condicionamento ácido. Obtidos os discos de dentina, a smear layer foi tratada com cloreto de potássio por 2 minutos (Grupo 1 - controle); com oxalato de dipotássio neutro por 2 minutos (Grupo 2); com solução de oxalato de potássio monohidrogenado a 3\% por 2 minutos - solução ácida com pH=2 (Grupo 3) e com oxalato de dipotássio a $30 \%$ por 2 minutos, seguido de oxalato de potássio monohidrogenado a 3\% por 2 minutos (Grupo 4). Após o tratamento, cada grupo foi condicionado com ácido cítrico a $6 \%$ por 2 minutos. Os resultados mostraram que os discos tratados com cloreto de potássio não tiveram a condutibilidade alterada e foram susceptíveis ao desafio ácido. Por outro lado, os discos tratados com soluções de oxalato tiveram uma redução significativa da permeabilidade e foram resistentes ao condicionamento ácido. O tratamento combinado de oxalatos não 
somente remove a smear layer e a substitui por uma camada de precipitados cristalinos, a qual oclui a dentina e é ácido resistente, como também resulta em uma superfície rica, tanto em cálcio como em carboxilatos, que auxiliam na adesão química.

PASHLEY; DEPEW ${ }^{72}$, em 1986, avaliaram o efeito da smear layer, do verniz cavitário e do oxalato na permeabilidadede dentinária e na microinfiltração. 0 oxalato reduziu a permeabilidade em $98,25 \%$ e não foi diferente quando a direção da filtração foi modificada. Como os cristais de oxalato de cálcio são insolúveis e resistentes ao condicionamento ácido, a permeabilidade dentinária, tendo o oxalato como agente intermediário, foi menor do que com qualquer outro agente testado.

PASHLEY; ANDRINGA; EICHMILLER ${ }^{71}$, em 1991, compararam a eficiência do oxalato de ferro, oxalato de potássio e do condicionador dentinário Tenure na redução da permeabilidade dentinária in vitro. Os resultados indicaram que o tratamento da dentina por 10 segundos proporcionou, para todos os agentes, um aumento da permeabilidade dentinária. Quando se aumentou o tempo para 30 segundos, houve uma diminuição da permeabilidade dentinária para as soluções à base de oxalato, e, com 60 segundos de aplicação, estas foram ainda mais eficazes. O tratamento com Tenure, que contém oxalato de alumínio a 2,5\%, não reduziu a permeabilidade dentinária aos níveis do tratamento realizado com oxalato. Isso pode ser explicado devido à concentração reduzida de oxalato de alumínio e também pela necessidade de um tempo maior de aplicação para que ocorra a 
formação de sais insolúveis, o que, para as soluções à base de oxalato, parece ocorrer após 30 segundos de aplicação.

KNIGHT et al. ${ }^{50}$, em 1993, examinaram, por microscopia eletrônica de varredura, o efeito de obliteração dos túbulos dentinários através da realização de procedimentos mecânicos e químicos. Os espécimes de dentina foram cortados transversalmente e divididos em dois grupos, sendo um experimental e outro grupo controle. Os tratamentos mecânicos foram realizados através de instrumentação contínua por 20 segundos com instrumentos de diferentes composições (metálicos e plásticos). Os tratamentos químicos incluíram resina composta, fluoretos, oxalatos de potássio e férrico, glicerina e nitrato de potássio. Os resultados revelaram que, entre os agentes mecânicos, a cureta afiada apresentou uma obliteração mais consistente e completa dos túbulos, e que os instrumentos plásticos não tiveram efeitos oclusivos sobre os túbulos. Entre os tratamentos químicos, a resina composta fotopolimerizável promoveu uma obliteração completa dos túbulos. O oxalato de potássio a $3 \%$ obliterou os túbulos com um grande número de pequenos cristais espalhados na superfície dentinária, mas não foi eficaz na obliteração dos túbulos, pois a maioria dos cristais desapareu após um spray de água. Os agentes à base de flúor e glicerina não apresentaram nenhum efeito oclusivo sobre os túbulos.

SHONO et al. ${ }^{88}$, em 1994, avaliaram in vitro a atuação de uma nova formulação de oxalato de potássio mais oxalato de alumínio na redução da 
permeabilidade dentinária e na alteração da superfície dentinária através de microscopia eletrônica de varredura. As medições da permeabilidade foram executadas antes e após a aplicação de uma solução salina (controle) e da solução experimental (oxalato de dipotássio a 5\% + oxalato de alumínio a 5\% em ácido nítrico a $2 \%, \mathrm{pH} 2$ ) por 10, 30 e 60 segundos. $\mathrm{O}$ tratamento da smear layer com a solução de oxalato produziu uma obliteração significativa dos túbulos. O tratamento da dentina condicionada com a solução experimental de oxalatos formou precipitados de tamanhos menores que os anteriores. O tamanho dos cristais e a espessura da camada de precipitado aumentou com o tempo do tratamento. Os resultados indicaram que a nova formulação de oxalatos obstruiu significativamente os túbulos dentinários, podendo ser utilizados como agentes anti-hiperestésicos ou mesmo como forrador cavitário.

MONGIORGI; PRATI ${ }^{60}$, em 1994, avaliaram o efeito de soluções de oxalato na condutibilidade hidráulica da dentina in vitro. Os 25 espécimes foram divididos em 5 grupos, e cada superfície dentinária recebeu o tratamento das soluções experimentais e controle por 2 minutos. Antes do tratamento, todos os espécimes foram condicionados com ácido fosfórico a 37\% por 2 minutos, a fim de remover a smear layer e simular a máxima permeabilidade (100\%). O tratamento com solução de cloreto de sódio a $0,9 \%$ (controle negativo) não teve efeito na permeabilidade dentinária. O tratamento com ponta diamantada (controle positivo), para criar smear layer, reduziu a permeabilidade de $100 \%$ para $2,9 \%$. Os espécimes tratados com Dentine Protect (ácido oxálico) reduziu a permeabilidade para 3,9\% do valor 
máximo. Todas as soluções de oxalato reduziram a permeabilidade a valores tão baixos quanto aos da smear layer (3,5\% e 2,2\%) e não houve diferenças estatísticas entre os tratamentos.

Um estudo in vitro realizado por PEREIRA, SEGALA; CARVALHO ${ }^{78}$, em 1996, teve por objetivo aumentar a reação do substrato dentinário ao oxalato de potássio. Foram utilizados 60 discos de dentina, divididos em 4 grupos, sendo três grupos tratados com três diferentes formulações de oxalato de potássio monohidratado (gel a $3 \% \mathrm{com}$ pH 4 - Oxa-Gel ${ }^{\circledR}$; gel a $6 \%$ com pH 4 e gel a $6 \%$ com $\mathrm{pH} 2,5$ ) aplicados por 3 minutos. O Grupo 4 foi tratado com fluorfosfato acidulado a $1,23 \%, \mathrm{pH} 4$, por 4 minutos. Cada grupo foi subdividido em 3 grupos e tratados de maneiras diversas:

a) condicionamento ácido com ácido cítrico a $6 \%$ por 1 minuto, lavados e secos com ar; b) condicionamento ácido e lavado somente, mantendo-se a umidade; c) condicionado, lavado e seco com papel absorvente; d) condicionado, não lavado e seco com ar; e) condicionado e seco com papel absorvente. Os resultados revelaram que todos os grupos apresentaram cristais de oxalato precipitados na embocadura dos túbulos. As condições condicionado/lavado/úmido e condicionado/não lavado mostraram os melhores resultados na oclusão dos túbulos.

JAIN, P. et al. ${ }^{43}$, em 1997, avaliaram in vitro o efeito de 4 agentes dessensibilizantes dentinários na oclusão dos túbulos, as modificações na 
superfície dentinária e os efeitos da saliva e da escovação. Os espécimes foram divididos em 5 grupos de 10 dentes cada. No Grupo 1 (controle), não foi realizado tratamento algum; no Grupo 2, a superfície dentinária foi tratada com Sensodyne Dentin Desensitizer (solução de oxalato de ferro a 6\%); no Grupo 3, foi utilizado Therma - Trol Desensitizer gel (solução de oxalato de potássio); o Grupo 4 foi tratado com Gluma Dentin Desensitizer (solução aquosa de glutaraldeído e HEMA) e, no Grupo 5,os espécimes foram tratados com All Bond. Os resultados mostraram que Sensodyne exibiu maior quantidade de oclusão de túbulos entre os dentes que não receberam escovação, seguido de Therma-Trol, Gluma e All Bond, nessa ordem. A escovação aumentou a oclusão dos túbulos em todos os casos, exceto para Sensodyne.

LING et al. ${ }^{54}$, em 1997, avaliaram in vitro o potencial do oxalato férrico (Sensodyne Sealant) e do oxalato de potássio (Butler Protect) de obliterar os túbulos dentinários. Os discos de dentina foram avaliados após a aplicação dos agentes através de microscopia eletrônica de varredura e microanálise por raio-x. Os resultados demonstraram que o oxalato férrico produziu cristais que obliteraram quase todas as aberturas tubulares, sendo superior ao oxalato de potássio. Foi observada a presença de componentes abrasivos (sílica e cálcio) tanto na superfície quanto no interior dos túbulos dentinários, indicando um certo potencial terapêutico desses dois componentes. Esses resultados sugerem que os agentes antihiperestésicos apresentam a propriedade de ocluir os túbulos in vitro, podendo ser indicados para tratamento in vivo. 
PEREIRA et al. $^{75}$, em 1997, avaliaram in vitro a capacidade de um gel de oxalato de potássio a $3 \%$ e de um gel de fluoreto a 1,23\% em reduzir o índice de filtração da água deionizada através da dentina secada com ar ou deixada levemente úmida. Após a obtenção dos discos de dentina, da remoção da smear layer com EDTA e da criação de nova smear layer com discos abrasivos, os espécimes foram submetidos a filtração e os índices mensurados para ambos os géis testados, sob as duas condições, e comparados à filtração básica. Os índices de filtração foram também mensurados após o desafio com ácido cítrico a 6\%. Os resultados demonstraram que o gel de oxalato de potássio a 3\% foi capaz de reduzir a filtração do fluido dentinário a níveis similares aos obtidos com a smear layer, mesmo após o desafio ácido.

Uma revisão de literatura realizada por SENA ${ }^{87}$, em 1990, sobre os agentes terapêuticos utilizados para o tratamento da hipersensibilidade dentinária, confirma a importância dos testes laboratoriais para um melhor entendimento do assunto. A preferência de modelos laboratoriais no estudo da hipersensibilidade dentinária deve-se a alguns fatores, tais como dificuldade do manejo clínico, problemas na seleção de pacientes e diagnóstico; e, ainda, a grande resposta do efeito placebo com referência à dor.

\subsection{AVALIAÇÃO CLÍNICA}


Diferentes métodos têm sido utilizados no tratamento da hiperestesia dentinária e, com freqüencia, as avaliações clínicas podem trazer resultados contraditórios, que se devem a variações no planejamento e nos procedimentos experimentais utilizados ${ }^{42}$.

\subsubsection{MENSURAÇÃO DA DOR ASSOCIADA À HIPERESTESIA DENTINÁRIA}

A dor, subjetiva por natureza e difícil de quantificar ${ }^{6}$, é o sintoma fundamental do paciente com hiperestesia dentinária. Pode ser definida como uma sensação não agradável e dependente de vários fatores, tais como: fatores individuais, que incluem idade, nível cognitivo, sexo, experiências anteriores; aprendizado familiar e cultural; fatores psicológicos, situacionais, comportamentais e emocionais ${ }^{58,62}$.

Vários são os estímulos que causam dor ou sensibilidade quando aplicados na superfície dentinária hiperestésica. As respostas a esses estímulos podem ser mensuradas clinicamente através de escalas de medida ou questionários específicos.

\subsubsection{Estímulos}

Em estudos sobre a dor e, especificamente, sobre a hiperestesia dentinária, é imprescindível que diferentes tipos de estímulos sejam utilizados, como por exemplo estímulos químicos, osmóticos, tácteis, térmicos e elétricos, que devem ser aplicados de forma consecutiva, porém com um intervalo de tempo para a recuperação da sintomatologia do estímulo anterior ${ }^{6}$. 
Segundo $\mathrm{ASH}^{4}$, em 1986, deve-se considerar a reprodutibilidade do estímulo e o controle dos fatores que podem influenciar no limiar da dor. Assim, o estímulo deve ser mensurável, reproduzível e previsível.

Segundo PASHLEY ${ }^{68}$, em 1990, vários são os estímulos que podem desencadear a hiperestesia dentinária, ou seja, estímulos tácteis, térmicos, evaporativos, elétricos e, ainda, soluções osmóticas. HOLLAND ${ }^{42}$ et al., em 1997, recomendam que sejam utilizados dois estímulos hidrodinâmicos, como estímulos sonda (tácteis) e jato de ar (térmico-evaporativo) por serem estímulos fisiológicos e controláveis.

O estímulo táctil pode ser representado pela utilização da sonda exploradora para identificar as regiões com hiperestesia dentinária ${ }^{57,68}$, deslizando-a no sentido mésio-distal ${ }^{6}$. Esse tipo de estímulo é amplamente utilizado pela maioria dos clínicos, pois é tão simples quanto efetivo ${ }^{68,92}$. A compressão da dentina pela sonda exploradora causa um deslocamento rápido do fluido no interior dos túbulos, ativando as terminações nervosas ${ }^{68}$.

HERNANDEZ et al. ${ }^{39}$, em 1972, utilizaram a sonda exploradora para diagnosticar hiperestesia dentinária em 276 pacientes, em avaliação clínica de dois dentifrícios anti-hiperestésicos comerciais. Essa sonda foi utilizada ao longo da área cervical exposta por um examinador, que teve o cuidado de aplicar sempre a mesma pressão. Segundo os autores, tal procedimento possibilita a localização exata da região com hiperestesia. Além disso, as sondas foram utilizadas somente em cinco avaliações, sendo descartadas posteriormente. 
O jato de ar é denominado estímulo evaporativo, pois, ao causar a movimentação do fluido, causa também a sua evaporação, modificando a normalidade e, como conseqüência, ativa as terminações nervosas ${ }^{56}$. Esse estímulo também pode ser considerado um estímulo térmico, dependendo da temperatura do jato de $\operatorname{ar}^{6}$. Apesar de não ser um estímulo quantitativo, o método pode ser considerado válido para testes de hiperestesia ${ }^{19}$.

Não existe uma padronização para a utilização desse estímulo quanto à distância do dente e tempo de aplicação. Segundo PASHLEY ${ }^{68}$, em 1990, alguns clínicos utilizam 0 jato de ar por 1 segundo, a 1 centímetro do dente, perpendicularmente e em temperatura ambiente; outros aumentam o tempo de aplicação para 2 ou 3 segundos, mas aumentam também a distância do dente para 10-12 centímetros. BERÁSTEGUI ${ }^{6}$, em 1999, recomenda a utilização do jato de ar entre $18-20^{\circ} \mathrm{C}$, por 1 segundo e a 1 centímetro do dente, tendo-se o cuidado de eliminar os possíveis resíduos de água para evitar a saída de ar úmido.

Segundo MATTHEWS; SHOWMAN; PASHLEY ${ }^{56}$, em 1993, o jato de ar é comumente utilizado para avaliar hiperestesia dentinária, embora seu mecanismo de ação não seja totalmente compreendido. Esses autores realizaram um estudo in vitro para medir os efeitos evaporativos em condições normais utilizando o jato de ar. Os objetivos deste estudo foram: medir a proporção de evaporação espontânea de água da dentina na presença e ausência de smear layer; medir a proporção de evaporação de água da dentina quando da aplicação direta de jatos de ar aquecidos na seringa tríplice ou uma peça de mão de alta rotação à distância de 1 a $10 \mathrm{~cm}$; e medir a proporção de evaporação de água da dentina induzidas por jatos de ar à 
temperatura de $10^{\circ} \mathrm{C}$ a $50^{\circ} \mathrm{C}$, a $1 \mathrm{~cm}$ da superfície de dentina. Os resultados demonstraram que os jatos de ar induziram um aumento de 15 a 30 vezes na perda de água por evaporação, a qual variou inversamente conforme a distância entre o jato de ar e o dente e diretamente conforme a temperatura do ar. O estímulo evaporativo pode superestimar o grau de hiperestesia, pois a evaporação de água ocorre facilmente através da smear layer. Segundo esses mesmos autores, a utilização do jato de ar como estímulo é um método simples e conveniente. Observam também que o dente é sensível ao ar em algum ponto da superfície dentinária exposta, e quando se deseja saber exatamente onde o dente é sensível ou quanto de superfície de dentina exposta é sensível, a sonda exploradora deve ser utilizada.

PASHLEY et al. ${ }^{70}$, em 1996, realizaram um estudo in vitro para medir a direção e a força da movimentação do fluido tubular em resposta a estímulos hidrodinâmicos, a fim de tornar possível a comparação e a equivalência entre os mesmos. Os resultados revelaram que os estímulos que causaram o maior movimento do fluido, em ordem decrescente, foram o calor, frio, jato de ar, soluções osmóticas e o estímulo táctil. Quando convertidos em unidades de equivalência, a ordem foi a mesma. Os autores observam também que, por se tratar de um estudo in vitro, não houve interferência dos fatores psicológicos.

\subsubsection{Quantificação da resposta - Escalas de medida}

GILLAM; NEWMAN, em $1993^{34}$, relataram que a hiperestesia dentinária tem sido avaliada com base na subjetividade da resposta de cada paciente sob a forma 
de Escalas de Medida Verbal (EMV) ou Escala Visual Analógica (EVA) e, ainda, através de questionários específicos. De acordo com esses autores, a interpretação da dor depende de cada estímulo e da natureza subjetiva da resposta, pois o paciente tem dificuldade em expressá-la. Segundo BERÁSTEGUI ${ }^{6}$, em 1999, quando estímulos tácteis, térmico-evaporativos ou ambos são utilizados, uma escala de 0 a 3 é recomendada, enquanto que, para estímulos osmóticos, a dor é classificada somente em ausente (0) ou presente (1).

Segundo McGRATH ${ }^{59}$, em 1986, os critérios para mensuração da dor são validade, versatilidade e realidade. A interpretação matemática é freqüentemente realizada de maneira arbitrária quando são designados valores numéricos aos escores de dor; a análise desses números, então, irá refletir se a diferença é quantitativa e não simplesmente qualitativa. Segundo a autora, duas são as categorias gerais de métodos que têm sido utilizados para a mensuração da dor humana: as categorias psicofísica e fisiológica. Existem, portanto, duas escalas subjetivas utilizadas na mensuração do grau de sensibilidade da dentina hiperestésica, sendo:

- ESCALA DE MEDIDA VERBAL (EMV)

Esta escala foi primeiramente descrita por KEELE ${ }^{47}$, em 1948 e, posteriormente modificada. São quatro graus de sensibilidade:

0 = dor ausente ou nenhum desconforto

1 = dor mínima ou mínimo desconforto

2 = dor moderada ou médio desconforto

3 = dor intensa ou grande desconforto por mais de 10 segundos 


\section{- ESCALA VISUAL ANALÓGICA (EVA)}

A EVA é uma linha de $10 \mathrm{~cm}$ de comprimento cujas extremidades representam os limites da dor. Os pacientes são questionados e assinalam o grau de sensibilidade ou desconforto quando da aplicação do estímulo nos diferentes níveis $^{33}$ :

$$
\begin{aligned}
& \mathbf{0}=\text { nenhuma dor } \\
& 6 \text { = forte } \\
& 1 \text { = quase imperceptível } \\
& 7 \text { = intensa } \\
& 2 \text { = muito leve } \\
& 8 \text { = muito intensa } \\
& 3=\text { leve } \\
& 9 \text { = extremamente intensa } \\
& 4 \text { = moderada } \\
& 10 \text { = a mais intensa dor imaginável } \\
& 5 \text { = levemente forte }
\end{aligned}
$$

HANSSON; BYE; SMITH ${ }^{38}$, em 1988, compararam a Escala Visual Analógica, a Escala Descritiva Verbal, a Escala Numérica e o Questionário de Dor de McGill na mensuração da dor associada à hiperestesia dentinária, utilizando a água gelada como estímulo. Os resultados demonstraram que existe uma correlação entre as escalas entre si, o que não ocorre entre as escalas e o questionário.

\subsubsection{Estudos de Avaliação Clínica}

Produtos como dentifrícios, géis e enxaguatórios bucais têm sido clinicamente testados com a finalidade de aliviar o desconforto causado pela hiperestesia dentinária. Os resultados desses estudos clínicos variam muito e alguns são inconclusivos devido à diversidade de metodologias utilizadas, à 
variabilidade de respostas subjetivas, à influência do efeito placebo ${ }^{31}$ e, ainda, segundo WEST et al. ${ }^{101}$, em 1997, à natureza subjetiva da mensuração da dor.

Nos estudos clínicos que têm por objetivo avaliar tratamentos para a hiperestesia dentinária, incluem-se, com freqüência, os dentifrícios. Esses estudos, apesar de utilizarem o mesmo método de mensuração de resposta ao tratamento (quanto ao estímulo e mensuração do grau de sensibilidade), possuem uma metodologia própria, já que a aplicação do agente anti-hiperestésico é realizada pelo próprio paciente em casa (delivery system), e não pelo cirurgião-dentista em consultório.

A literatura revisada a seguir enfatiza os estudos de avaliação clínica nos quais foram utilizados produtos que atuam por obliteração dos canalículos dentinários, sejam estes os denominados delivery systems ou os aplicados pelo profissional em consultório odontológico, com a finalidade de destacar a metodologia utilizada no que se refere aos estímulos empregados e ao método de mensuração da hiperestesia dentinária, bem como os resultados.

JENSEN; DOERING ${ }^{44}$, em 1987, realizaram um estudo comparativo entre uma solução anti-hiperestésica contendo fluoreto de sódio e cloreto de estrôncio com um agente adesivo fotopolimerizável, o qual não requeria que a smear layer fosse removida e nem que houvesse a penetração nos túbulos para sua retenção. Foram selecionados 38 pacientes com uma média de 3,2 dentes pré-molares ou anteriores com hiperestesia dentinária. A avaliação do grau de sensibilidade foi realizada através de uma escala verbal de 0 a 3, utilizando-se como estímulo uma 
sonda exploradora afiada e jato de ar em temperatura ambiente. Cada paciente recebeu dois tratamentos: o primeiro consistiu na aplicação de uma solução de fluoreto de sódio a $0,42 \%$ e cloreto de estrôncio a 3,96\%, a qual foi aplicada ativamente por 3 minutos após profilaxia e secagem do dente, sendo os excessos removidos com um algodão. No segundo tratamento, o adesivo fotopolimerizável Scotchbond foi aplicado após os dentes terem recebido o mesmo tratamento do grupo anterior. Os pacientes foram reavaliados após 3 e 6 meses. Os resultados demonstraram que o adesivo Scotchbond foi o mais efetivo na redução da hiperestesia dentinária.

ORCHARDSON; COLLINS ${ }^{63}$, em 1987, avaliaram 109 pacientes com sintomas de hiperestesia dentinária. Esses pacientes foram questionados sobre a duração, localização e como ocorria a dor, bem como o tipo de escova e dentifrício utilizados. O grau de sensibilidade foi mensurado através de estímulos mecânicos (sonda e jato de ar), os quais, segundo os mesmos autores, são testes reproduzíveis. Nesse estudo, a maioria dos pacientes reportou que o jato de ar, tanto sozinho como em combinação com outro estímulo, causou o maior desconforto.

MUZZIN; JOHNSON ${ }^{61}$, em 1989, compararam os efeitos individual e combinado do oxalato de dipotássio a $30 \%$ e do oxalato monopotássio monohidrogenado a 3\% na redução da hiperestesia dentinária in vivo. Foram selecionados 17 pacientes, cada um com 4 dentes hiperestésicos, num total de 68 
faces vestibulares. Esses dentes foram divididos em quatro grupos. Cada paciente recebeu os quatro tratamentos, sendo um tratamento por dente: Grupo 1: água destilada seguida de oxalato de dipotássio a 30\%; Grupo 2: água destilada seguida de oxalato monopotássio-monohidrogenado a 3\%; Grupo 3: oxalato de dipotássio a 30\% seguido de oxalato monopotássio-monohidrogenado a 3\%; Grupo 4 (controle) : água destilada seguida de água destilada. Para mensurar as respostas (sim ou não), foi utilizado um teste térmico (frio) através do uso de água em diferentes temperaturas $\left(20^{\circ} \mathrm{C}, 15^{\circ} \mathrm{C}, 10^{\circ} \mathrm{C}, 5^{\circ} \mathrm{C}\right.$ e $10^{\circ} \mathrm{C}$, com uma variação de $\pm 1^{\circ} \mathrm{C}$ para cada intervalo de temperatura). A temperatura que resultava em uma resposta sensitiva era registrada para cada dente testado. Além da avaliação antes da aplicação das substância e imediatamente depois, foram realizadas avaliações após 1, 2 e 4 semanas. Os resultados demonstraram uma significativa redução da hiperestesia dentinária nas avaliações imediata e após 4 semanas quando comparadas ao baseline nos dentes tratados com água destilada seguida de oxalato monopotássiomonohidrogenado a 3\% (Grupo 2). Para esse mesmo grupo, não houve diferença estatisticamente significante quando comparados os dados do baseline com os resultados obtidos após 1 ou 2 semanas. Os melhores resultados foram obtidos no Grupo 3 (oxalato de dipotássio a $30 \%$ seguido de oxalato monopotássiomonohidrogenado a 3\%), em que uma redução de grande significância estatística foi observada em 1 e 2 semanas após o tratamento.

COOLEY; SANDOVAL ${ }^{18}$, em 1989, avaliaram a eficácia do oxalato de potássio na redução da sensibilidade dentinária. Participaram deste estudo clínico 
28 pacientes com dentes sensíveis em duas diferentes áreas da boca. Os pacientes avaliados não poderiam apresentar cárie ou cálculo no dente sensível. Em uma primeira consulta, as informações foram colhidas através de um questionário. Para a avaliação do grau de sensibilidade, foi utilizada uma escala verbal de 0 a 5 com a finalidade de obter-se uma melhor distribuição das respostas. Após isolamento relativo, um dente foi tratado com água destilada e o outro, com oxalato de potássio monohidrogenado, aplicando-se neles cada agente por 2 minutos. Imediatamente após o tratamento, os pacientes fizeram o teste de sensibilidade ingerindo um copo com água gelada $\left(10^{\circ} \mathrm{C}\right)$, e o questionário foi novamente aplicado. Esse tratamento foi repetido no intervalo de 1 semana, 1 mês e 3 meses. Os resultados indicaram que ambos os tratamentos obtiveram uma redução na sensibilidade estatisticamente significante após a aplicação dos agentes. A sensibilidade dos dentes tratados com água destilada permaneceu constante nos tempos avaliados (1 semana, 1 mês e 3 meses), ao passo que a sensibilidade dos dentes tratados com oxalato de potássio-monohidrogenado aumentou progressivamente no mesmo período, tanto que ao final de 3 meses não houve diferença estatística entre os valores obtidos antes do tratamento. Esse resultado obtido com o uso da água destilada pode ser atribuído ao efeito placebo e a fatores psicogênicos que devem ser considerados quando da realização de estudos que envolvem a dor.

KERNS et al. ${ }^{48}$, em 1991, avaliaram clinicamente a obliteração dos túbulos através de procedimentos clínicos como raspagem e alisamento radicular e aplicação de soluções de oxalato de potássio, utilizando, como controle, dentes 
tratados com EDTA. Para tanto, foi desenvolvido um modelo de avaliação in vivo. Foram realizados cortes de $2 \mathrm{~mm} \times 3 \mathrm{~mm}$ imediatamente abaixo da junção amelodentinária em dentes extraídos. Após os diferentes tratamentos, esses fragmentos foram incorporados a uma prótese parcial removível, que foi instalada no próprio doador do dente extraído. As avaliações foram realizadas através de microscopia eletrônica de varredura. Os resultados demonstraram que, após 7 dias, os dentes tratados com oxalato de potássio apresentaram poucos cristais e que os túbulos estavam abertos. Após 4 semanas, o diâmetro dos túbulos tratados com oxalato de potássio diminuiu significativamente. Os autores concluíram que a criação de smear layer ou a aplicação de oxalatos, tendo em vista a oclusão dos túbulos dentinários, são procedimentos de curta duração, mas que podem oferecer um conforto ao paciente até que ocorra a obliteração natural dos túbulos dentinários.

OYAMA; MATSUMOTO ${ }^{64}$, em 1991, realizaram um estudo clínico para avaliar a correlação entre a morfologia superficial dos túbulos dentinários e a hiperestesia. Foram examinados 105 incisivos e molares de pacientes com hiperestesia dentinária. Feitas as réplicas da dentina cervical, a superfície dos dentes foi secada com algodão e, posteriormente, lavada por 3 minutos, alternando-se esponjas embebidas em álcool a $70 \%$ e solução de hipoclorito a 5\%. Por fim, as áreas afetadas foram lavadas com água destilada e secadas com jatos de ar. O grau de sensibilidade dentinária foi medido através de uma Escala de Medida Verbal (EMV) de 0 a 3, utilizando-se o jato de ar como estímulo. A dentina cervical hiperestésica foi examinada de duas maneiras: com uma sonda exploradora, que foi passada 
cuidadosamente, e através de um estímulo elétrico. As áreas hiperestésicas foram, então, fotografadas e comparadas com as réplicas. Os resultados mostraram uma correlação estatisticamente significante entre a morfologia dos túbulos dentinários e a hiperestesia dentinária.

HOLBOROW ${ }^{41}$, em 1994, avaliou a eficácia de uma solução comercial antihiperestésica de oxalato monopotássio-monohidrogenado a 3\% (Butler Protect), utilizando como controle água que continha um corante similar. Foram selecionados 30 pacientes com dois dentes hiperestésicos. Cada dente foi testado com sonda exploradora e água gelada, e o grau de sensibilidade foi mensurado em uma Escala de Medida Verbal (EMV) de 0 a 3. Cada paciente recebeu as duas soluções. As avaliações foram realizadas imediatamente após as aplicações e 7, 14 e 28 dias depois. Os resultados demonstraram não haver diferença estatisticamente significante entre os grupos controle e experimental em qualquer etapa da avaliação. Quando a sonda foi utilizada como estímulo, os resultados foram semelhantes, ao passo que, com o estímulo frio, houve uma diferença estatisticamente significante na redução da hiperestesia dentinária quanto ao uso da solução experimental no $28^{\circ}$ dia. $O$ autor concluiu que, para a sensibilidade ao frio, o oxalato de monopotássio monohidrogenado é eficaz e que, para o estímulo sonda, os resultados são inconclusivos devido à dificuldade de localizar precisamente a mesma área hiperestésica da superfície radicular nos diferentes períodos. 
PEARCE; ADDY; NEWCOMBE ${ }^{74}$, em 1994, compararam clinicamente a eficácia de três dentifrícios: dois dentifrícios anti-hiperestésicos contendo sal de estrôncio e outro fluoretado. Um total de 119 pacientes completaram o tratamento. O grau de sensibilidade foi obtido no baseline e após 1, 4, 8 e 12 semanas. Foram utilizados como estímulos o jato de ar aplicado com a seringa tríplice por 3 segundos a $3 \mathrm{~mm}$ da dentina exposta, uma sonda termoelétrica a $0^{\circ} \mathrm{C}$ e, ainda, uma sonda clínica, que foi passada horizontalmente sobre a dentina exposta. O grau de sensibilidade foi, primeiramente, mensurado através da Escala de Medida Verbal (EMV) de 0 a 3 e, após a aplicação de cada estímulo individualmente, o grau de sensibilidade foi novamente mensurado, utilizando a Escala Analógica Verbal (EAV) de 0 a 10 . Os resultados desse estudo demonstraram que os dois dentifrícios contendo estrôncio apresentaram redução semelhante, a qual não se mostrou maior do que aquela observada em relação ao dentifrício convencional fluoretado.

SILVERMAN; GINGOLD; CURRO ${ }^{89}$, em 1994, compararam, em 62 pacientes, a eficácia de um dentifrício comercial contendo 3,75\% de cloreto de potássio e 0,8\% de monofluorfosfato de sódio (Sensodyne) com um dentifrício contendo somente cloreto de potássio; foi usado, ainda, um dentifrício placebo, que continha todos os ingredientes, com exceção do cloreto de potássio e do monofluorfosfato de sódio. Os estímulos utilizados foram a sonda exploradora e o jato de ar (a $19-21^{\circ} \mathrm{C}$ por 1 segundo), sendo o grau de sensibilidade avaliado de acordo com a Escala de Medida Verbal (de 0 a 3) no baseline e após 2,4,e 8 semanas. Os resultados demonstraram que os dentifrícios contendo cloreto de potássio com ou sem 
monofluorfosfato de sódio reduziram significativamente a hiperestesia dentinária aos estímulos táctil e jato de ar.

PEREIRA et al. ${ }^{76}$, em 1994, avaliaram o tratamento da hiperestesia dentinária em 28 pacientes submetidos a procedimento periodontal. O grau de sensibilidade foi avaliado através da utilização de sonda exploradora e jato de ar/água e mensurado através de uma Escala de Medida Verbal, sendo 0 - ausência de dor, 1 dor mínima, 2 - dor moderada e 3 - dor intensa por mais de 10 segundos. Cento e quarenta dentes foram tratados com oxalato de potássio $\left(\mathrm{Oxa}-\mathrm{Gel} \mathrm{I}^{\circledR}\right)$ durante quatro semanas, sob isolamento relativo. Como controle, um placebo foi utilizado em 82 dentes nas mesmas condições e período. A hiperestesia dentinária foi avaliada antes e imediatamente após a aplicação do agente anti-hiperestésico semanalmente durante quatro semanas. Após esse período, os dentes que ainda se apresentavam hiperestésicos foram novamente tratados. Os resultados indicaram que, após 4 semanas de tratamento com o Oxa-Gel ${ }^{\circledR}$, uma redução significativa da hiperestesia foi observada, pois $88,5 \%$ dos dentes apresentaram ausência de dor ou dor mínima. Os resultados com o placebo foram semelhantes (76,8\%). Após 06 meses, foram avaliados $94,5 \%$ dos dentes, os quais mantiveram baixos índices de hiperestesia; e, ainda, após 8 meses, o percentual encontrado foi de $87,7 \%$ em 47 dentes avaliados.

YAMAMOTO, H. et al. $^{104}$, em 1995 , examinaram a posição dos cristais precipitados após o tratamento com oxalato de potássio em dentina exposta de 
cães in vivo. A estabilidade dos cristais também foi avaliada através do exame da superfície tratada e dos túbulos após uma semana de exposição ao ambiente oral. A dentina foi exposta com a utilização de brocas e, após o condicionamento ácido, a superfície foi tratada com oxalato de dipotássio a $30 \%$ seguido de oxalato monohidrogenado a $3 \%$. Após o tratamento com o oxalato, numerosos cristais foram encontrados, tanto na superfície como no interior dos túbulos (100um). A densidade dos cristais na superfície dentinária e no interior dos túbulos foi diminuindo após 1 semana de exposição à cavidade oral. A dentina estava coberta com smear layer, mas muitos túbulos dentinários estavam abertos e ampliados, e cristais foram encontrados nas porções mais profundas dos túbulos. Os resultados indicam que a precipitação de cristais de oxalato in vivo ocorre não somente na superfície dentinária, mas também no interior dos túbulos, e que a precipitação de cristais no interior dos túbulos ocorreu somente quando a smear layer foi removida por ácidos.

GILLAM et al. ${ }^{32}$, em 1996, compararam a eficácia de dois enxaguatórios bucais, um contendo nitrato de potássio, sílica e fluoreto de sódio e outro contendo apenas sílica e fluoreto de sódio na redução da hiperestesia dentinária em 50 indivíduos durante 6 semanas. Os estímulos utilizados foram a sonda de Yeaple e o jato de ar (a $19 \pm 3^{\circ} \mathrm{C}$ por 1 segundo), sendo o grau de sensibilidade mensurado através da Escala Analógica Verbal (EAV) de 0 a 10. Os resultados demonstraram que o enxaguatório contendo nitrato de potássio a 3\%/sílica/fluoreto de sódio 
apresentou uma redução significativa da hiperestesia dentinária quando foram utilizados os estímulos táctil e térmico.

ESTRELA, C. et al. $^{24}$, em 1996, realizaram um estudo com 160 dentes (caninos e pré-molares) portadores de hipersensibilidade dentinária observada após tratamento periodontal. Cada produto testado foi aplicado em 20 dentes com diferentes graus de hiperestesia. As avaliações foram executadas no período de 7, 15, 30 e 60 dias, sendo a sonda exploradora (estímulo táctil) usada com a mesma pressão pelo mesmo avaliador; e estímulo térmico (teste da água fria e do jato de ar). A mensuração do grau de hiperestesia foi realizada através da Escala de Medida Verbal de 0 a 3 . No Grupo 1, foi utilizada água destilada como agente placebo, por meio da aplicação por 2 min. com bolinhas de algodão. No Grupo 2, o fluoreto de sódio foi aplicado por $5 \mathrm{~min}$, sendo que, no primeiro minuto, fez-se brunidura com o auxílio de uma taça de borracha. No Grupo 3, aplicou-se a pasta de hidróxido de cálcio com água destilada, seguindo o mesmo critério do Grupo 2. Nos Grupos 4 e 5, foram aplicados o Oxa-gel ${ }^{\circledR}$ e o Duraphat, seguindo-se as instruções dos fabricantes. Nos Grupos 6, 7, e 8, aplicaram-se os sistemas adesivos Scotchbond Multi-uso Plus, Optibond e Multibond Alpha conforme as recomendações dos fabricantes e empregando-se o ácido fosfórico a 37\% por 15 segundos para o condicionamento. Com exceção dos sistema adesivos, que foram utilizados somente uma vez, os demais produtos foram novamente aplicados a cada período de observação. Os resultados indicaram que o hidróxido de cálcio e o fluoreto de sódio a $2 \%$ apresentaram os menores valores na redução da dor pós- 
tratamento para os 3 níveis de sensibilidade. O Duraphat e o sistema adesivo Multibond Alpha mostraram valores intermediários em todos os níveis de sensibilidade. Para o grau de sensibilidade 1, o sistema adesivo Optibond e o Oxagel $^{\circledR}$ demonstraram os melhores valores de redução da dor $(88,8 \%$ e $87,5 \%$, respectivamente). Para os graus 2 e 3 de sensibilidade, o Oxa-Gel ${ }^{\circledR}$ e o sistema adesivo Scotchbond Multi-uso Plus mostraram os melhores resultados (sendo $87,5 \%$ e $75,0 \%$ para o grau 2 , e $75,0 \%$ e $75,0 \%$ para o grau 3 , respectivamente). Pode-se notar a ocorrência de baixa redução de dor imediatamente após a aplicação dos sistemas adesivos para os 3 diferentes graus de sensibilidade, com melhora expressiva aos 30 dias. No Grupo 1 (controle), mesmo empregando um agente placebo (água destilada), verificou-se que, para o nível 1 de sensibilidade, a redução de dor pós-tratamento alcançou $40 \%$ aos 60 dias.

GILLAM et al. ${ }^{31}$, em 1997, compararam in vivo um adesivo (All-bond 2 ) e um produto à base de oxalato de potássio (Butler Protect) em 55 dentes, tendo cada um deles um outro dente sensível como controle. Os estímulos utilizados foram o táctil (sonda de Yeaple) e o jato de ar $\left(19\right.$ a $24^{\circ} \mathrm{C}$ a $1 \mathrm{~cm}$ e aplicado perpendicularmente); o grau de sensibilidade foi mensurados através da Escala Analógica Verbal (EAV) de 0 a 10, antes, depois de meio minuto e após 1, 2 e 3 meses. Os resultados demonstraram que houve uma tendência à diminuição da hiperestesia dentinária para todos os grupos, sendo que nenhuma diferença estatisticamente significante foi detectada entre os grupos. 
WEST et al. ${ }^{101}$, em 1997, compararam clinicamente três produtos em 112 pacientes: um dentifrício anti-hiperestésico à base de estrôncio e outro à base de potássio, ambos contendo flúor, e um dentifrício convencional com flúor. Os estímulos utilizados foram táctil (sonda exploradora) através pressão relativamente constante, e jato de $\operatorname{ar}\left(17\right.$ a $21^{\circ} \mathrm{C}$, aplicado perpendicularmente por 3 segundos a 1 $3 \mathrm{~mm}$ do dente). O grau de sensibilidade foi mensurado através da Escala Analógica Verbal (EAV) de 0 a 10 no baseline e após 2 e 6 semanas. Os resultados indicaram que todos os grupos apresentaram uma diminuição da hiperestesia dentinária; essa diminuição, porém, não foi estatisticamente significante entre os grupos em qualquer intervalo de tempo.

PLAGMANN, et al. ${ }^{79}$, em 1997, compararam dois dentifrícios (um contendo fluoreto de amina e o outro fluoreto de sódio) a um dentifrício placebo no tratamento da hiperestesia dentinária através de uma avaliação clínica de 8 semanas. O grau de hiperestesia foi avaliado através de estímulos táctil (sonda de Yeaple) e evaporativo (jato de ar com temperatura entre 19 e $21^{\circ} \mathrm{C}$, aplicado por 1 segundo) e mensurado de acordo com a Escala Verbal Analógica (de 0 a 10) e com a resposta subjetiva do paciente. Os três grupos apresentaram graus de sensibilidade semelhantes no baseline. Os resultados demonstraram que os dentifrícios são eficazes na diminuição da hiperestesia dentinária, mas não diferem estatisticamente dos resultados obtidos com o uso do dentifrício placebo. 
YEATES et al. ${ }^{105}$, em 1998, avaliaram clinicamente, em 38 pacientes selecionados, a eficácia do fosfato de cálcio na obliteração dos túbulos dentinários, utilizando um placebo como controle. Foram utilizados como estímulos a sonda exploradora (passada horizontalmente sobre a lesão, sob pressão controlada) e, após 5 minutos, utilizou-se $\mathrm{o}$ jato de ar (por 2 segundos, a $19^{\circ} \mathrm{C} \pm 5^{\circ} \mathrm{C}$ perpendicularmente a $1 \mathrm{~cm}$ do dente) e também água gelada $\left(a 10^{\circ} \mathrm{C}\right.$ e $\left.0^{\circ} \mathrm{C}\right) . \mathrm{O}$ grau de sensibilidade foi mensurado através da Escala Analógica Verbal (0 a 10) no baseline e após $2,7,14,21,28,56$ e 84 dias. Os resultados demonstraram que houve uma diminuição considerável da hiperestesia, mas não ocorreu diferença estatisticamente significante entre os materiais. Os autores concluíram que, ou o fosfato de cálcio não teve efeito terapêutico, ou o efeito foi mascarado pelo placebo.

CARVALHO; DIAS ${ }^{12}$, em 1999, avaliaram a eficácia de três substâncias (flúor gel tópico acidulado Sultan; Oxa-Gel ${ }^{\circledR}$ e Arnica a 35\% em Orobase) no tratamento da hiperestesia dentinária cervical. Foram selecionados 45 pacientes que, na primeira consulta, receberam instruções de higiene bucal, profilaxia e tiveram a hiperestesia dentinária avaliada através de ficha clínica. As soluções foram reaplicadas a cada 7 dias, durante 4 semanas. A hiperestesia dentinária foi avaliada após 30 e 60 dias. Os resultados indicaram que não houve diferença estatística significante entre a Arnica e o Oxa-Gel ${ }^{\circledR}$, que foram os agentes mais eficazes no tratamento da hiperestesia dentinária que do que o flúor. 
3 PROPOSIÇÃO 


\section{PROPOSIÇÃO}

Devido à grande incidência de hiperestesia dentinária e à diversidade de opções de tratamento, este estudo propõe-se a:

1. avaliar clinicamente as respostas imediata e mediata de dentes com hiperestesia dentinária, após a aplicação de duas diferentes formulações à base de oxalato de potássio (Solução Experimental 1 e Solução Experimental 2), e de um agente anti-hiperestésico comercial $\left(\mathrm{Oxa}-\mathrm{Gel}^{\circledR}\right)$, utilizando-se um placebo como controle.

2. determinar a tendência evolutiva do tratamento no decorrer das etapas de aplicação dos agentes anti-hiperestésicos estudados em comparação com a condição inicial (baseline). 
4 MATERIAL E MÉTODO 


\section{MATERIAL E MÉTODO}

O presente trabalho foi realizado adotando-se os seguintes procedimentos:

\subsection{MATERIAL}

\subsubsection{Seleção dos Pacientes:}

Os pacientes participantes desta pesquisa foram selecionados na Clínica Integrada, no Serviço de Triagem e entre funcionários e alunos da Faculdade de Odontologia de Bauru a partir dos seguintes critérios:

- pacientes que se queixavam de sensibilidade na região cervical de dentes posteriores e/ou anteriores, com ou sem lesões cervicais não cariosas;

- pacientes que tinham interesse pelo tratamento dessa sensibilidade e que dispunham de tempo para sua realização, dando-se preferência àqueles que residiam no município de Bauru;

- pacientes sem registro de doenças sistêmicas e psicológicas graves;

- pacientes com saúde bucal em condições de permitir um diagnóstico correto da hiperestesia dentinária;

- pacientes que se manifestaram de acordo com os métodos utilizados na pesquisa, conforme os princípios éticos recomendados na Declaração de Helsinki ${ }^{103}$.

Com base nesses critérios, selecionaram-se inicialmente 26 pacientes, os quais foram convidados a comparecer à Clínica de Pós-Graduação da Faculdade de Odontologia de Bauru, com horário marcado. Em uma primeira consulta, esses pacientes foram entrevistados e examinados para verificação da condição bucal e 
dos dentes que seriam utilizados na investigação. Dentre eles, então, foram selecionados 19 pacientes que apresentavam dentes caninos e pré-molares com sensibilidade cervical (hiperestesia dentinária), sendo que, dentre esses, 12 indivíduos pertenciam ao sexo masculino $(63,15 \%)$ e 07 , ao sexo feminino $(36,84 \%)$. A idade média variou entre 21 e 45 anos para o sexo masculino e entre 22 e 41 anos para o sexo feminino. As informações relatadas nos Quadros 4.1 a 4.7 foram obtidas através do questionário aplicado aos pacientes (Anexo 4.2):

Quadro 4.1: Resultado do questionário geral aplicado aos pacientes selecionados.

\begin{tabular}{|l|c|c|c|c|c|}
\hline QUESTIONÁRIO & $\mathbf{S}$ & $\mathbf{\%}$ & $\mathbf{N}$ & $\mathbf{\%}$ & $\mathbf{T}$ \\
\hline Já fez algum tratamento ou cirurgia periodontal ? & $\mathbf{0 3}$ & 15,8 & 16 & 84,2 & 19 \\
\hline Se já fez, a dor existia antes deste tratamento? & 01 & 33,3 & 02 & 66,7 & $\mathbf{0 3}$ \\
\hline $\begin{array}{l}\text { Já fez algum tipo de tratamento para diminuir esta } \\
\text { dor? }\end{array}$ & 04 & 21,0 & 15 & 79,0 & 19 \\
\hline $\begin{array}{l}\text { Tem o hábito de ranger os dentes durante o dia } \\
\text { ou noite? }\end{array}$ & 09 & 47,4 & 10 & 52,6 & 19 \\
\hline Tem algum problema de saúde? & 0 & 0 & 19 & 100 & 19 \\
\hline Está tomando algum medicamento? & 0 & 0 & 19 & 100 & 19 \\
\hline
\end{tabular}

Onde: $\mathbf{S}=\operatorname{Sim}, \mathbf{N}=$ Não e $\mathbf{T}=$ Total

Obs: Apesar de $47,4 \%$ dos pacientes relatarem hábitos de bruxismo ou bruxomania, não foram encontrados sinais clínicos referentes a essas situações clínicas.

Quadro 4.2: Padrão de higienização bucal.

\begin{tabular}{|c|c|c|}
\hline PADRÃO DE HIGIENIZAÇÃO BUCAL ${ }^{84}$ & BOM & 06 \\
\hline & REGULAR & 12 \\
\hline & RUIM & 01 \\
\hline & TOTAL & 19 \\
\hline
\end{tabular}


Quadro 4.3: Número de higienizações que o paciente realiza diariamente.

\begin{tabular}{|l|l|l|}
\hline $\mathbf{N}^{\mathbf{0}}$ HIGIENIZAÇõES/ DIA & 3 VEZES/DIA & 09 \\
\hline & 4 VEZES/DIA & 09 \\
\cline { 2 - 3 } & MAIS VEZES/DIA & 01 \\
\cline { 2 - 3 } & TOTAL & 19 \\
\cline { 2 - 3 }
\end{tabular}

Quadro 4.4: Freqüência do consumo de alimentos ou bebidas ácidas (tipo de dieta).

\begin{tabular}{|l|l|l|}
\hline TIPO DE DIETA (FREQUÊNCIA) & REFRIGERANTES & 05 \\
\hline \multirow{yy}{*}{} & FRUTAS ÁCIDAS & 03 \\
\cline { 2 - 3 } & AMBOS & 02 \\
\cline { 2 - 3 } & NENHUM DESTES & 09 \\
\cline { 2 - 3 } & TOTAL & 19 \\
\hline
\end{tabular}

Quadro 4.5: Estímulos necessários para desencadear a hiperestesia.

\begin{tabular}{|c|l|c|}
\hline $\begin{array}{c}\text { ESTÍMULO NECESSÁRIO PARA } \\
\text { DESENCADEAR A DOR }\end{array}$ & AR & 09 \\
\cline { 2 - 3 } & ÁGUA GELADA & 11 \\
\hline \multirow{3}{*}{ ESCOVA DENTAL } & 10 \\
\cline { 2 - 3 } & ALIMENTO ÁCIDO & 07 \\
\cline { 2 - 3 } & OUTROS & 02 \\
\cline { 2 - 3 }
\end{tabular}

Quadro 4.6: Tipo de escova dental utilizada pelo paciente.

\begin{tabular}{|l|l|l|}
\hline TIPO DE ESCOVA DENTAL & MACIA & 15 \\
\hline & EXTRA-MACIA & 03 \\
\cline { 2 - 3 } & DURA & 01 \\
\cline { 2 - 3 } & TOTAL & 19 \\
\hline
\end{tabular}

OBS: Alguns pacientes relataram dor a mais de um estímulo, não sendo possível igualar o total de respostas ao total de pacientes. 
Quadro 4.7: Marca comercial do dentifrício utilizado pelo paciente.

\begin{tabular}{|l|l|l|}
\hline MARCA COMERCIAL DO & COLGATE & 09 \\
\cline { 2 - 3 } DENTIFRÍCIO UTILIZADO & SORRISO & 06 \\
\hline & SIGNAL & 03 \\
\cline { 2 - 3 } & OUTROS & 03 \\
\hline
\end{tabular}

OBS: Alguns pacientes relataram o uso alternado de diferentes marcas comerciais de dentifrícios; portanto, o total não coincide com o total de pacientes

Esses pacientes foram informados do propósito da pesquisa e do método a ser utilizado e, após estarem cientes dos procedimentos a serem realizados, assinaram uma autorização para pesquisa clínica e execução de tratamento (Anexo 4.1), que foi complementada com um questionário anamnético para registro de suas condições sistêmicas e comportamentais, conforme os critérios apontados acima.

Esse primeiro exame clínico e anamnese foram realizados com a finalidade de diagnosticar a provável etiologia da hiperestesia dentinária, descartando-se a possibilidade da sensibilidade ser proveniente de outras causas. $O$ exame radiográfico seria utilizado no caso de persistir alguma dúvida quanto ao diagnóstico da hiperestesia.

\subsubsection{Seleção dos Dentes:}

Entre os 19 pacientes, foram selecionados 94 dentes caninos e pré-molares que apresentavam sensibilidade dentinária, resultando em uma média de aproximadamente 05 dentes por paciente, seguindo-se os critérios ${ }^{15,46}$ :

1. Padrão de higiene bucal: de regular para bom. Segundo SANGNES; GJERMO ${ }^{84}$, em 1976, os padrões de higiene bucal estariam assim definidos: 
- Bom: após secagem com jato de ar, nenhuma placa bacteriana fosse visível em nenhum elemento dental.

- Ruim: se mais de um quarto dos dentes apresentasse acúmulo de placa bacteriana.

- Regular: qualquer situação entre as duas condições anteriores.

2. Grupo dentário: caninos e pré-molares.

3. Condição geral do dente selecionado: não poderia apresentar cáries, trincas ou fraturas, restaurações extensas ou insatisfatórias, prótese ou aparelhos de contenção e forças oclusais anormais.

4. Condição periodontal: foram selecionados dentes com ausência de bolsas periodontais e mobilidade.

5. Oclusão: o paciente selecionado não deveria apresentar trauma oclusal acentuado.

6. Características da lesão: foram selecionados dentes que apresentavam recessão gengival ou qualquer tipo de lesão cervical, desde que houvesse sensibilidade.

7. Etiologia: as lesões foram selecionadas independentemente da etiologia, considerando-se a abfração e a perimólise como fatores etiológicos principais.

8. Tratamento anterior: o paciente não poderia ter utilizado nenhum agente desensibilizante e, se o fez, deveria ter sido há pelo menos 06 meses. 


\subsubsection{Instrumentos e Materiais:}

Nesta pesquisa clínica foram utilizados os seguintes instrumentos e materiais: Instrumentos

- Espelho plano $n^{\circ} 5$ (Barash)

- Explorador duplo $n^{0} 5$ (ref. 11.510, Duflex, S.S. White)

- Pinça clínica nº 317 (ref. 11.905, Duflex, S.S. White)

- Aplicadores descartáveis (Microbrush Coporation, USA)

- Potes de Dappen

- Timer

\section{Materiais}

- Algodão hidrófilo

- Bastonetes (Topz ${ }^{\circledR}$ - Nature's Plus Farmacêutica Ltda., Hortolândia, SP)

- Carbopol (fornecido pelo laboratório Emelffar Comercial Ltda., S.P. - Brasil)

- Carboximetil celulose (fornecido por Henrifarma Produtos Químicos e Farmacêuticos Ltda., S.P. - Brasil)

- Oxalato de potássio monohidratado (marca NUCLEAR)

- Oxalato de potássio Oxa-Gel ${ }^{\circledR}$ (Art-Dent Ind. Com. Ltda. - Brasil)

- Papel absorvente

- Roletes de algodão

- Tiras de papel carbono para articulação AccuFilm (Dental Brand Comercial Ltda., S.P. - Brasil) 


\subsection{MÉTODO}

Cada paciente foi submetido a um questionário específico com o objetivo de obter-se o máximo de informações sobre a hiperestesia dentinária. Esse questionário avaliou o paciente como um todo, os dentes individualmente e as lesões cervicais em particular.

Na Ficha de Identificação (Anexo 4.2), o registro do relato do paciente foi de grande importância para esclarecer as características da manifestação da dor, duração e estímulo desencadeador. Algumas particularidades também foram investigadas, por exemplo, se o paciente já havia se submetido a algum tratamento ou cirurgia periodontal, se a sensibilidade existia antes desse tratamento e se já havia sido tratada anteriormente. Outras informações também foram obtidas através de perguntas específicas ao paciente quanto à sua alimentação e higienização dos dentes, bem como hábitos de bruxismo ou bruxomania. As condições sistêmicas foram novamente avaliadas, dando-se ênfase a relatos de problemas digestivos, acidez e xerostomia, diabetes e hipertireoidismo. As condições psicossomáticas também foram avaliadas com relação a anorexia, bulimia e uso de psicotrópicos e álcool por parte do paciente.

Após a identificação dos dentes caninos e pré-molares hiperestésicos, cada lesão cervical foi avaliada quanto à forma (cunha ou pires), localização (face), tamanho (pequena/ média/grande), profundidade (rasa/média/ profunda) e provável etiologia. Todos os dentes selecionados foram tratados independentemente das características da lesão cervical e da provável etiologia. 


\subsubsection{Determinação dos Padrões de Hiperestesia}

Cada dente selecionado recebeu dois estímulos: sonda exploradora (estímulo táctil) e jato de ar (térmico-evaporativo). A aplicação do estímulo sonda foi realizada de forma que a mesma percorresse toda a extensão da lesão, sob pressão controlada, após treinamento pelo mesmo operador, até que o paciente relatasse dor semelhante à que o fez procurar por tratamento. $O$ jato de ar foi aplicado sobre a dentina exposta com a seringa tríplice a uma pressão de 80 libras, por 1 segundo, a temperatura de aproximadamente $20^{\circ} \mathrm{C}$ e a $1 \mathrm{~cm}$ do dente, sem promover $\mathrm{O}$ ressecamento da superfície dentinária. Após cada estímulo, avaliou-se o Grau de Sensibilidade, que segue uma Escala de Medida Verbal (EMV) ${ }^{47}$ de 0 a 3 (Quadro 4.8), selecionando-se dentes que apresentavam sensibilidade ao estímulo sonda e/ou ar:

Quadro 4.8:- Escala de Medida Verbal ${ }^{47}$.

\begin{tabular}{|c|l|}
\hline $\begin{array}{c}\text { Grau de } \\
\text { Sensibilidade }\end{array}$ & \multicolumn{1}{|c|}{ Significado } \\
\hline $\mathbf{0}$ & Dor ausente \\
\hline $\mathbf{1}$ & Dor mínima ou mínimo desconforto \\
\hline $\mathbf{2}$ & Dor moderada ou médio desconforto \\
\hline $\mathbf{3}$ & Dor intensa ou grande desconforto por mais de $10 \mathrm{~s}$. \\
\hline
\end{tabular}

\subsubsection{Grupos experimentais}

Os 94 dentes (caninos e pré-molares) selecionados foram divididos aleatoriamente em quatro grupos, conforme mostra o seguinte quadro: 
Quadro 4.9:- Distribuição dos dentes por grupos de acordo com o material.

\begin{tabular}{|c|l|c|}
\hline GRUPOS & \multicolumn{1}{|c|}{ MATERIAIS } & N $^{\mathbf{0}}$ DENTES \\
\hline GRUPO 1 & Oxa-Gel $^{\circledR *}$ & 23 \\
\hline GRUPO 2 & Solução Experimental 1 & 27 \\
\hline GRUPO 3 & Solução Experimental 2 & 27 \\
\hline GRUPO 4 & Placebo & 17 \\
\hline \multicolumn{2}{|c|}{ TOTAL DE DENTES } & $\mathbf{9 4}$ \\
\hline
\end{tabular}

*Art-Dent Ind. Com. Ltda. - Brasil

Os agentes anti-hiperestésicos utilizados neste experimento, sua composição e pH estão relacionados no Quadro 4.10 abaixo:

Quadro 4.10:- Agentes anti-hiperestésicos, sua composição e pH.

\begin{tabular}{|l|l|c|}
\hline \multicolumn{1}{|c|}{ MATERIAL } & \multicolumn{1}{|c|}{ COMPOSIÇÃO } & pH \\
\hline Oxa-Gel $^{\left(\otimes_{*}\right.}$ & $\mathrm{KOx}^{* *}$ a $3 \%+$ Carboximetil celulose & 4 \\
\hline Solução Experimental 1 & $\mathrm{KOx}^{* *}$ a $6 \%+$ Carboximetil celulose & 4 \\
\hline Solução Experimental 2 & $\mathrm{KOx}^{* *}$ a $3 \%+$ Carbopol & 2 \\
\hline Placebo & $\mathrm{H}_{2} \mathrm{O}+$ Carboximetil celulose & 7 \\
\hline
\end{tabular}

* Art-Dent Ind. Com. Ltda. - Brasil

** KOx = Oxalato de Potássio Monohidratado

A fim de tornar possível a correlação dos dados no que se refere ao limiar de sensibilidade de cada paciente, tomou-se o cuidado de destinar diferentes soluções anti-hiperestésicas para um mesmo paciente.

Na consulta seguinte, avaliou-se o Grau de Sensibilidade (0, 1, 2 ou 3) pela Escala de Medida Verbal (EMV) utilizando-se a sonda exploradora e o jato de ar conforme explicado. Após a anotação dos escores, realizou-se a primeira aplicação 
de uma das quatro substâncias a serem testadas. As aplicações foram realizadas da seguinte maneira:

a) isolamento relativo com roletes de algodão;

b) aplicação de bolinhas de algodão umedecidas em água sobre a dentina;

c) secagem da dentina com papel absorvente, para que a mesma permanecesse úmida ${ }^{78}$;

d) aplicação passiva da solução a ser testada com pincel Microbrush por 3 minutos, controlados através de um timer;

e) remoção dos excessos com bastonetes.

Imediatamente após a aplicação, avaliou-se novamente o grau de hiperestesia aos mesmos estímulos, conforme já descrito. Todos os dados, tais como datas, dentes e soluções testadas foram anotados em uma Ficha de Controle das Aplicações (Anexo 4.3), individual para cada paciente.

Esse procedimento foi repetido a cada 07 dias durante quatro semanas, de forma a obter o registro periódico da hiperestesia antes (baseline) e imediatamente após a aplicação dos agentes anti-hiperestésicos em estudo. Os escores obtidos imediatamente após a quarta aplicação estabeleceram o que se denominou resultados imediatos do tratamento.

Decorridos 06 meses da quarta aplicação, os pacientes foram reconvocados para nova avaliação do Grau de Sensibilidade dos dentes aos estímulos ar e sonda exploradora, baseando-se na Escala de Medida Verbal (EMV). A comparação entre 
os dados obtidos nesta avaliação com o baseline e aqueles coletados após a quarta aplicação determinou os resultados mediatos do tratamento. 


\section{ANEXO 4.1}

\section{AUTORIZAÇÃO PARA PESQUISA CLÍNICA E EXECUÇÃO DE TRATAMENTO}

Título do Projeto: "Avaliação da hiperestesia dentinária após tratamento com diferentes formulações à base de oxalato de potássio, utilizando um placebo como controle".

Responsável: C.D. Ana Christina Bonato Figueiredo Martineli

Orientador: Prof. Dr. José Carlos Pereira

Nome do paciente:

Por este instrumento de autorização por mim assinado, dou pleno consentimento à FACULDADE DE ODONTOLOGIA DE BAURU para, por intermédio de seus professores, profissionais e alunos devidamente autorizados, fazer diagnóstico, planejamento, fotografias e tratamento odontológico em minha pessoa, de acordo com os conhecimentos enquadrados no campo dessa especialidade.

Concordo também, que a documentação referente a exames efetuados e quaisquer outras informações concernentes ao planejamento de diagnóstico e tratamento constituem propriedade exclusiva desta Faculdade, à qual dou plenos direitos de uso para fins de ensino e de divulgação, respeitando os respectivos códigos de ética.

Bauru, de de 199

\section{Assinatura do paciente ou responsável}

Documento apresentado: $\mathrm{N}^{\mathrm{O}}$

\section{QUESTIONÁRIO DE SAÚDE}

Já teve hemorragia?

Tem alergia a algum produto ou medicamento?

Teve reumatismo infeccioso?

Sofre ou sofreu de algum distúrbio cardiovascular?

É diabético ou tem familiares diabéticos?

Já desmaiou alguma vez?

Está em tratamento médico?

Está tomando algum medicamento?

Esteve doente ou foi operado nos últimos 05 anos?

Tem hábitos, vícios ou manias?

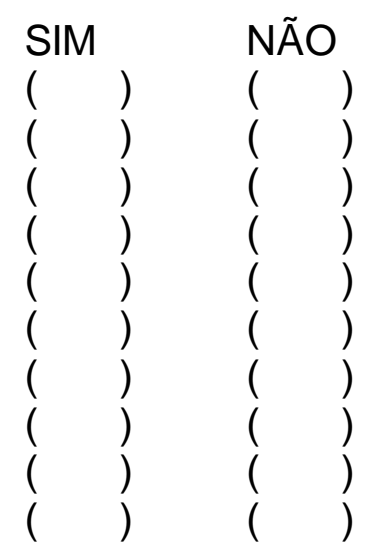




\section{ANEXO 4.2}

FICHA DE IDENTIFICAÇÃO $\mathrm{N}^{\circ}$

Data I

\section{DADOS GERAIS DO PACIENTE:}

Nome

Endereço $n^{\circ}$ Apto.

Bairro CEP Fone

Cidade Estado Data Nasc.

Idade Sexo ( ) Fem. Nacionalidade

Profissão Local de Trabalho

Endereço do Trabalho Fone

Outras informações

Relato do paciente Já fez algum tratamento ou cirurgia periodontal?

Se já fez, a dor existia antes deste tratamento ?

Como aparece esta dor, qual o estímulo necessário (ar, alimentos doces ou gelados, ao escovar os dentes) ?

Já fez algum tipo de tratamento para diminuir esta dor?

Se já fez, qual o tratamento utilizado?

Qual o tipo de sua dieta (frutas ácidas, refrigerantes)?

Como escova os seus dentes?

Quantas vezes ao dia? Qual é o dentifrício utilizado ?

Qual o tipo de escova de dentes utilizada (dura, macia, extra-macia)?

Tem o hábito de ranger os dentes ou apertá-los durante o dia ou à noite ?

Tem algum problema de saúde (diabetes, hipertireoidismo, xerostomia, problemas digestivos, acidez)?

Tem algum problema psicossomático como anorexia, bulimia e outros ?

Faz uso de algum medicamento ou droga (psicotrópicos ou álcool) ?

Padrão de higiene oral: ( ) bom ( ) regular ( ) ruim 


\section{DENTES:}

\begin{tabular}{|c|c|c|c|c|c|c|}
\hline Dente & Tipo de Dor & Rel. Ocl & Fac.desg & Cárie & C.Perio. & Rest. \\
\hline & & & & & & \\
\hline & & & & & & \\
\hline & & & & & & \\
\hline & & & & & & \\
\hline & & & & & & \\
\hline & & & & & & \\
\hline & & & & & & \\
\hline & & & & & & \\
\hline & & & & & & \\
\hline & & & & & & \\
\hline & & & & & & \\
\hline & & & & & & \\
\hline & & & & & & \\
\hline
\end{tabular}

Dor: $\mathbf{P}$ - provocada $\mathbf{E}$ - espontânea $\mathbf{M}$ - momentânea $\mathbf{I}$ - intermitente

Percussão: $\mathbf{V +}$ - vertical positiva $\quad$ H+ - horizontal positiva

LESÃO:

\begin{tabular}{|c|c|c|c|c|c|c|}
\hline \multirow[t]{2}{*}{ Dente } & \multicolumn{2}{|c|}{ Tipo de Lesão } & \multicolumn{2}{|c|}{ Localização } & \multirow{2}{*}{\multicolumn{2}{|c|}{ Profundidade }} \\
\hline & Cunha & Pires & Face & Região & & \\
\hline & & & & & & \\
\hline & & & & & & \\
\hline & & & & & & \\
\hline & & & & & & \\
\hline & & & & & & \\
\hline & & & & & & \\
\hline
\end{tabular}


ANEXO 4.3

FICHA DE CONTROLE DE APLICAÇÕES

Paciente: Ficha $\mathbf{n}^{\circ}$

Soluções utilizadas:

( ) Oxa- Gel

Solução Experimental 1

) Placebo

) Solução Experimental 2

Atendimento

Estímulo

Antes da $1^{\circ}$

aplicação

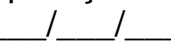

Depois da $1^{\circ}$

aplicação

1

Antes da $2^{\circ}$

aplicação

1

Depois da $2^{\circ}$

aplicação

I_ I

Antes da $3^{\circ}$

aplicação

1

Depois da $3^{\circ}$

aplicação

I

Antes da $4^{\circ}$

aplicação

1

Depois da $4^{\circ}$

aplicação

11

06 meses da

$4^{\circ}$ aplicação 


\section{RESULTADOS}




\section{RESULTADOS}

A distribuição dos espécimes por escore dentro de cada grupo pode ser visualizada no Quadro 5.1. Através desse quadro observa-se que, dentro de cada grupo, existe uma padronização do número de dentes com determinado grau de sensibilidade (mínimo, moderado e intenso). Esta uniformidade da amostra quanto ao grau de sensibilidade é importante em estudos de hiperestesia pois evita que, por exemplo, um determinado agente seja testado em um grupo de dentes com grau de sensibilidade diferente daquele apresentado por outro grupo, o que pode influenciar sobremaneira a interpretação dos resultados.

Quadro 5.1: Distribuição de espécimes por escore dentro de cada grupo.

\begin{tabular}{|c|c|c|c|c|c|c|}
\hline \multicolumn{7}{|c|}{ ESTÍMULO } \\
\hline \multirow[b]{2}{*}{ GRUPOS } & \multicolumn{2}{|c|}{ SONDA } & \multicolumn{2}{|c|}{ AR } & \multicolumn{2}{|c|}{ SONDA / AR } \\
\hline & ESCORE & $\begin{array}{c}\mathrm{n}^{\circ} \\
\text { DENTES }\end{array}$ & ESCORE & $n^{\circ}$ DENTES & ESCORE & $\begin{array}{c}\mathrm{n}^{0} \\
\text { DENTES }\end{array}$ \\
\hline $\begin{array}{c}\text { GRUPO } \\
1\end{array}$ & $\begin{array}{l}\text { DMi } \\
\text { DMo } \\
\text { DI }\end{array}$ & $\begin{array}{l}19 \\
08-42,1 \% \\
08-42,1 \% \\
03-15,8 \%\end{array}$ & $\begin{array}{l}\text { DMi } \\
\text { DMo } \\
\text { DI }\end{array}$ & $\begin{array}{l}=23 \\
03-13,0 \% \\
12-52,2 \% \\
08-34,8 \%\end{array}$ & $\begin{array}{l}\text { DMi } \\
\text { DMo } \\
\text { DI }\end{array}$ & $\begin{array}{l}23 \\
02-8,7 \% \\
12-52,2 \% \\
09-39,1 \%\end{array}$ \\
\hline $\begin{array}{c}\text { GRUPO } \\
2\end{array}$ & $\begin{array}{l}\text { DMi } \\
\text { DMo } \\
\text { DI }\end{array}$ & $\begin{array}{l}21 \\
10-47,6 \% \\
08-38,1 \% \\
03-14,3 \%\end{array}$ & $\begin{array}{l}\text { DMi } \\
\text { DMo } \\
\text { DI }\end{array}$ & $\begin{array}{l}=26 \\
05-19,2 \% \\
15-57,6 \% \\
06-23,0 \%\end{array}$ & $\begin{array}{l}\text { DMi } \\
\text { DMo } \\
\text { DI }\end{array}$ & $\begin{array}{l}27 \\
04-14,8 \% \\
15-55,6 \% \\
08-29,6 \%\end{array}$ \\
\hline $\begin{array}{c}\text { GRUPO } \\
3\end{array}$ & $\begin{array}{l}\text { DMi } \\
\text { DMo } \\
\text { DI }\end{array}$ & $\begin{array}{l}24 \\
06-25,0 \% \\
13-54,1 \% \\
05-20,9 \% \\
\end{array}$ & $\begin{array}{l}\text { DMi } \\
\text { DMo } \\
\text { DI }\end{array}$ & $\begin{array}{l}=27 \\
06-22,2 \% \\
12-44,4 \% \\
09-33,3 \%\end{array}$ & $\begin{array}{l}\text { DMi } \\
\text { DMo } \\
\text { DI }\end{array}$ & $\begin{array}{l}27 \\
03-11,1 \% \\
14-51,9 \% \\
10-37,0 \%\end{array}$ \\
\hline $\begin{array}{c}\text { GRUPO } \\
4\end{array}$ & $\begin{array}{l}\text { DMi } \\
\text { DMo } \\
\text { DI }\end{array}$ & $\begin{array}{l}14 \\
06-42,8 \% \\
06-42,8 \% \\
02-14,3 \% \\
\end{array}$ & $\begin{array}{l}\text { DMi } \\
\text { DMo } \\
\text { DI }\end{array}$ & $\begin{array}{l}=17 \\
03-17,6 \% \\
09-53,0 \% \\
05-29,4 \%\end{array}$ & $\begin{array}{l}\text { DMi } \\
\text { DMo } \\
\text { DI }\end{array}$ & $\begin{array}{l}17 \\
03-17,6 \% \\
09-53,0 \% \\
05-29,4 \% \\
\end{array}$ \\
\hline
\end{tabular}


Através da Ficha de Controle das Aplicações (Anexo 4.3, em Material e Método), pode-se tabular os dados nos diferentes momentos do tratamento e, assim, observar a variação percentual do grau de hiperestesia dentinária de acordo com a Escala de Medida Verbal (EMV). As Tabelas de 29 a 49, contidas no Apêndice, apresentam essa variação e comparam os escores obtidos antes da primeira aplicação (baseline) com aqueles obtidos imediatamente após cada aplicação semanal para cada um dos agentes anti-hiperestésicos (Oxa-Gel ${ }^{\circledR}$; Solução Experimental 1; Solução Experimental 2 e Placebo), usando-se os estímulos sonda e ar. Foram realizadas, ainda, comparações entre o grau de sensibilidade registrado no baseline e imediatamente após a quarta aplicação com os resultados obtidos na reavaliação após 06 meses. Uma análise dos resultados de cada grupo, independente do estímulo utilizado, pode ser visualizada nas Tabelas de 50 a 57, também apresentadas no Apêndice.

Diante do grande número de informações e variações na abordagem dos dados, optou-se por descrever os resultados do Grupo 1 do experimento (Oxa-Gel ${ }^{\circledR}$ ) de forma detalhada e completa, a fim de facilitar a compreensão quanto à evolução do tratamento. Esse primeiro lote de dados, contidos nas Tabelas de 5.1 a 5.4, compreende as comparações entre os escores de hiperestesia determinados pela sonda no baseline (imediatamente antes do tratamento) e aqueles obtidos imediatamente após as $1^{\mathrm{a}}, 2^{\mathrm{a}}, 3^{\mathrm{a}}$ e $4^{\mathrm{a}}$ aplicações do Oxa-Gel ${ }^{\circledR}$. Esse grupo de dados iniciais será considerado como resultado imediato do tratamento. A Tabela 5.5 compara, então, os resultados obtidos após 6 meses com o baseline, e a Tabela 
5.6 compara os resultados imediatos da $4^{\mathrm{a}}$ aplicação com aqueles encontrados após 6 meses, ambos denominados de resultados mediatos.

Para os demais grupos experimentais, como resultados serão apresentadas somente as tabelas referentes à comparação entre o baseline e após a $4^{a}$ aplicação dos materiais (resultado imediato) além das tabelas contendo os resultados mediatos obtidos após 6 meses comparados ao baseline e aos resultados após quatro aplicações. Entretanto, todas as tabelas com a distribuição dos resultados nos demais períodos são apresentadas no Apêndice.

Convém salientar que essas tabelas expressam simplesmente a disposição geométrica dos valores absolutos e relativos da hiperestesia dentinária antes e após as etapas de tratamento com os diferentes agentes e sob diferentes estímulos. A abordagem estatística desses resultados será apresentada mais adiante.

As Tabelas de 5.1 a 5.6 mostram os resultados referentes ao Grupo 1 (Oxa$\left.\mathrm{Gel}^{\circledR}\right)$, em que se empregou a sonda como estímulo. Essas tabelas, assim como as demais, permitem a visualização da progressão do efeito anti-hiperestésico do material empregado conforme a evolução do tratamento. Assim, é possível comparar o número de dentes com determinado grau de hiperestesia antes da primeira aplicação dos respectivos materiais e seu efeito subseqüente.

Na Tabela 5.1, por exemplo, pode-se notar que, de um total de 19 dentes que apresentavam hiperestesia dentinária antes da primeira aplicação, $8(42,1 \%)$ tinham dor mínima (DM-1), 8 (42,1\%) dor moderada (DMo-2) e $3(15,8 \%)$ dor intensa (DI-3). De acordo com essa tabela, observa-se também que, dos 8 dentes com dor mínima 
antes do tratamento, $2(10,5 \%)$ acusaram ausência de sensibilidade imediatamente após a aplicação do Oxa-Gel ${ }^{\circledR} ; 4(21,0 \%)$ continuaram apresentando dor mínima e 2 $(10,5 \%)$ passaram a apresentar dor moderada, ou seja, acusaram um aumento no grau de hiperestesia. Dos 8 dentes (42,1\%) com dor moderada, 1 (5,3\%) acusou desaparecimento da hiperestesia, 4 (21,0\%) passaram a ter dor mínima e $3(15,7 \%)$ continuaram com dor moderada. E, finalmente, 2 (10,5\%) dos 3 dentes com dor intensa antes da primeira aplicação do Oxa-Gel ${ }^{\circledR}$, acusaram dor moderada, enquanto 1 dente $(5,2 \%)$ continuou com dor intensa. A análise dos extremos direito e inferior da Tabela 5.1 oferece, ainda, uma visão geral da variação dos graus de hiperestesia iniciais e imediatamente após o tratamento, quando se constatou que 3 dentes (15,8\%) apresentaram completo desaparecimento da dor, 8 (42,1\%) ainda tinham dor mínima, 7 (36,8\%) mostraram dor moderada e apenas 1 (5,2\%), dor intensa. A partir dessa primeira aplicação de $\mathrm{Oxa}-\mathrm{Ge}{ }^{\circledR}{ }^{\circledR}$, iniciou-se a concentração de dentes com respostas hiperestésicas mais baixas ou ausentes quando estimulados pela sonda exploradora.

TABELA 5.1 - Variação da sensibilidade dentinária no Grupo 1 (Oxa-Gel ${ }^{\circledR}$ ) utilizando-se a sonda como estímulo, comparando-se os resultados obtidos antes e depois da primeira aplicação.

\begin{tabular}{|c|c|c|c|c|c|c|}
\hline \multirow{2}{*}{\multicolumn{2}{|c|}{$\begin{array}{c}\text { OXA-GEL } \\
\text { SONDA }\end{array}$}} & \multicolumn{5}{|c|}{ DEPOIS DA $1^{\text {a }}$ APLICAÇÃO } \\
\hline & & DA (0) & DMi (1) & DMo (2) & DI (3) & TOTAL \\
\hline ANTES & DA $\quad(0)$ & 00 & 00 & 00 & 00 & 00 \\
\hline DA & DMi (1) & $02(10,5 \%)$ & $04(21,0 \%)$ & $02(10,5 \%)$ & 00 & $08(42,1 \%)$ \\
\hline $1^{a}$ & DMo (2) & 01 (5,3\%) & $04(21,0 \%)$ & $03(15,8 \%)$ & 00 & $08(42,1 \%)$ \\
\hline APLIC. & DI (3) & 00 & 00 & $02(10,5 \%)$ & $01(5,3 \%)$ & $03(15,8 \%)$ \\
\hline
\end{tabular}




\begin{tabular}{|l|l|l|l|l|l|}
\hline TOTAL & $03(15,8 \%)$ & $08(42,1 \%)$ & $07(36,8 \%)$ & $01(5,3 \%)$ & 19 \\
\hline
\end{tabular}

Na Tabela 5.2, que compara o efeito anti-hiperestésico do Oxa-Gel ${ }^{\circledR}$ depois da segunda aplicação com o baseline (antes da primeira aplicação), pode-se observar que pouca modificação ocorreu em relação ao quadro anterior, exceto pelo fato de que houve uma redução do número de dentes com ausência de dor (2:10,5\%) e um aumento do número de dentes com dor mínima (9:47,3\%).

TABELA 5.2 - Variação da sensibilidade dentinária no Grupo 1 (Oxa-Gel ${ }^{\circledR}$ ) utilizando-se a sonda como estímulo, comparando-se os resultados obtidos antes da primeira aplicação e depois da segunda aplicação.

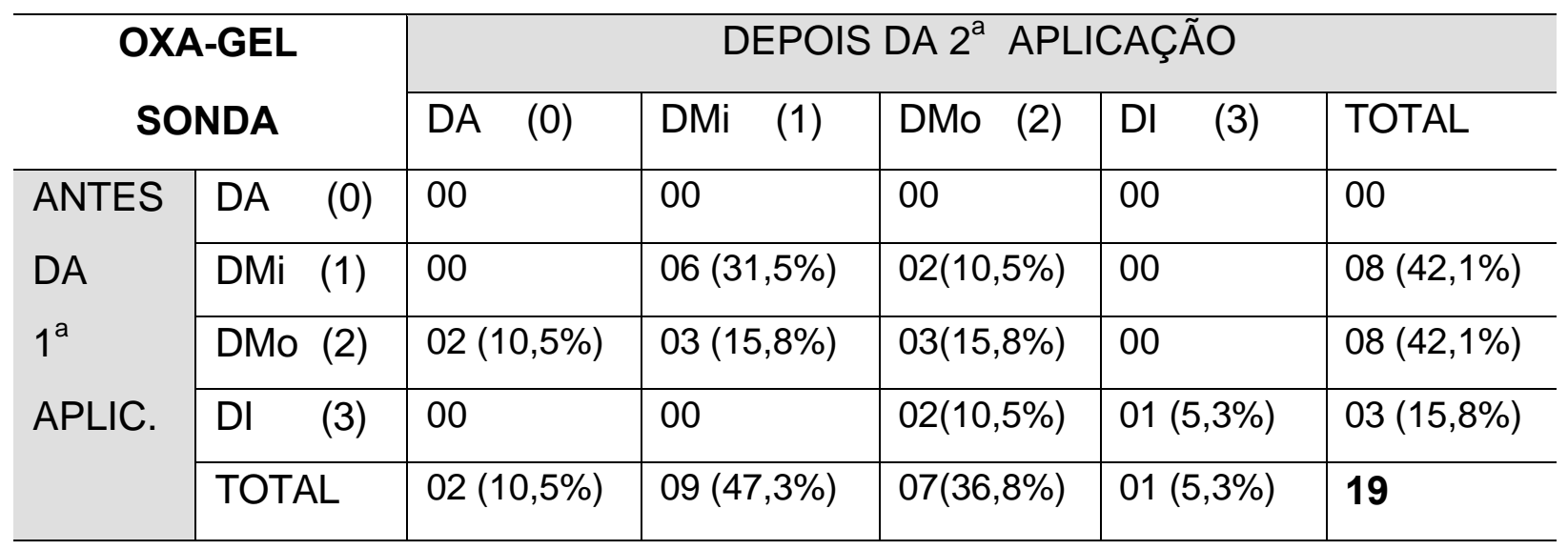

A partir da Tabela 5.3, torna-se evidente a concentração de dentes com hiperestesia de graus 0 e 1 em 5 (26,5\%) e 10 (52,5\%) dentes respectivamente.

TABELA 5.3 - Variação da sensibilidade dentinária no Grupo 1 (Oxa-Gel $\left.{ }^{\circledR}\right)$ utilizando-se a sonda como estímulo, comparando-se os resultados obtidos antes da primeira aplicação e depois da terceira aplicação. 


\begin{tabular}{|c|c|c|c|c|c|c|}
\hline \multirow{2}{*}{\multicolumn{2}{|c|}{$\begin{array}{c}\text { OXA-GEL } \\
\text { SONDA }\end{array}$}} & \multicolumn{5}{|c|}{ DEPOIS DA $3^{\mathrm{a}}$ APLICAÇÃO } \\
\hline & & $\mathrm{DA} \quad(0)$ & $\mathrm{DMi} \quad(1)$ & DMo (2) & DI (3) & TOTAL \\
\hline \multirow{5}{*}{$\begin{array}{l}\text { ANTES } \\
\text { DA } \\
1^{\mathrm{a}} \\
\text { APLIC. }\end{array}$} & $\mathrm{DA} \quad(0)$ & 00 & 00 & 00 & 00 & 00 \\
\hline & DMi (1) & $03(15,8 \%)$ & $05(26,3 \%)$ & 00 & 00 & $08(42,1 \%)$ \\
\hline & DMo (2) & $02(10,5 \%)$ & $02(10,5 \%)$ & $04(21,0 \%)$ & 00 & $08(42,1 \%)$ \\
\hline & DI (3) & 00 & $03(15,8 \%)$ & 00 & 00 & $03(15,8 \%)$ \\
\hline & TOTAL & $05(26,3 \%)$ & $10(52,6 \%)$ & $04(21,0 \%)$ & 00 & 19 \\
\hline
\end{tabular}

A tendência à concentração de dentes nos escores mais baixos é ainda mais clara na Tabela 5.4, onde não se notam dentes com hiperestesia de graus moderados (2) ou intenso (3) depois da $4^{\mathrm{a}}$ aplicação do Oxa-Gel ${ }^{\circledR}$.

TABELA 5.4 - Variação da sensibilidade dentinária no Grupo 1 (Oxa-Gel ${ }^{\circledR}$ ) utilizando-se a sonda como estímulo, comparando-se os resultados obtidos antes da primeira aplicação e depois da quarta aplicação.

\begin{tabular}{|c|c|c|c|c|c|c|}
\hline \multirow{2}{*}{\multicolumn{2}{|c|}{$\begin{array}{c}\text { OXA-GEL } \\
\text { SONDA }\end{array}$}} & \multicolumn{5}{|c|}{ DEPOIS DA $4^{\mathrm{a}}$ APLICAÇÃO } \\
\hline & & $\mathrm{DA} \quad(0)$ & DMi (1) & DMo (2) & DI (3) & TOTAL \\
\hline \multirow{5}{*}{$\begin{array}{l}\text { ANTES } \\
\text { DA } \\
1^{\mathrm{a}} \\
\text { APLIC. }\end{array}$} & $\mathrm{DA} \quad(0)$ & 00 & 00 & 00 & 00 & 00 \\
\hline & DMi (1) & $05(26,3 \%)$ & $03(15,8 \%)$ & 00 & 00 & $08(42,1 \%)$ \\
\hline & DMo (2) & $02(10,5 \%)$ & $06(31,5 \%)$ & 00 & 00 & $08(42,1 \%)$ \\
\hline & DI (3) & $01(5,3 \%)$ & $02(10,5 \%)$ & 00 & 00 & $03(15,8 \%)$ \\
\hline & TOTAL & $08(42,1 \%)$ & $11(57,9 \%)$ & 00 & 00 & 19 \\
\hline
\end{tabular}


Dos 19 dentes com hiperestesia dentinária estimulados pela sonda exploradora no baseline, 16 foram reavaliados após 6 meses do tratamento com Oxa-Gel ${ }^{\circledR}$. A Tabela 5.5 demonstra que, antes da primeira aplicação, 7 dentes (43,7\%) apresentavam dor mínima, 8 (50,0\%), dor moderada e 1 (6,2\%), dor intensa; após 6 meses, 7dentes (43,7\%) apresentaram dor ausente, 4 (25,0\%), dor mínima, 5 dentes $(31,2 \%)$, dor moderada e nenhum apresentou dor intensa.

TABELA 5.5 - Variação da sensibilidade dentinária no Grupo 1 (Oxa-Gel ${ }^{\circledR}$ ) utilizando-se a sonda como estímulo, comparando-se os resultados obtidos antes da primeira aplicação e depois de 06 meses.

\begin{tabular}{|c|c|c|c|c|c|c|}
\hline \multirow{2}{*}{\multicolumn{2}{|c|}{$\begin{array}{c}\text { OXA-GEL } \\
\text { SONDA }\end{array}$}} & \multicolumn{5}{|c|}{ DEPOIS DE 06 MESES } \\
\hline & & DA (0) & DMi (1) & DMo (2) & DI (3) & TOTAL \\
\hline \multirow{2}{*}{$\begin{array}{l}\text { ANTES } \\
\text { DA }\end{array}$} & $\begin{array}{ll}\mathrm{DA} & (0)\end{array}$ & 00 & 00 & 00 & 00 & 00 \\
\hline & DMi (1) & $04(25,0 \%)$ & $01(6,2 \%)$ & $02(12,5 \%)$ & 00 & $07(43,7 \%)$ \\
\hline $1^{a}$ & DMo (2) & $03(18,7 \%)$ & $02(12,5 \%)$ & $03(18,7 \%)$ & 00 & $08(50,0 \%)$ \\
\hline \multirow[t]{2}{*}{ APLIC. } & $\mathrm{DI} \quad(3)$ & 00 & $01(6,2 \%)$ & 00 & 00 & $01(6,2 \%)$ \\
\hline & TOTAL & $07(43,7 \%)$ & $04(25,0 \%)$ & $05(31,2 \%)$ & 00 & 16 \\
\hline
\end{tabular}

OBS: O número de dentes diminuiu porque nem todos os pacientes compareceram à avaliação de 06 meses.

Na Tabela 5.6, observam-se 07 dentes (43,7\%) com ausência de hiperestesia, 04 (25,0\%) com hiperestesia mínima e 05 (31,2\%) que retornaram ao grau moderado. Como essa tabela compara o resultado imediato (após a $4^{\mathrm{a}}$ aplicação) com aquele obtido 06 meses após o tratamento, pode-se observar que 02 dentes (12,5\%) evoluíram de ausência de hiperestesia para hiperestesia de grau mínimo, ao mesmo tempo em que dos 9 dentes $(56,0 \%)$ com dor mínima no 
resultado imediato, $2(12,5 \%)$ tornaram-se assintomáticos, e $5(31,2 \%)$ evoluíram para dor moderada.

TABELA 5.6 - Variação da sensibilidade dentinária no Grupo 1 (Oxa-Gel ${ }^{\circledR}$ ) utilizando-se a sonda como estímulo, comparando-se os resultados obtidos depois da quarta aplicação e depois de 06 meses.

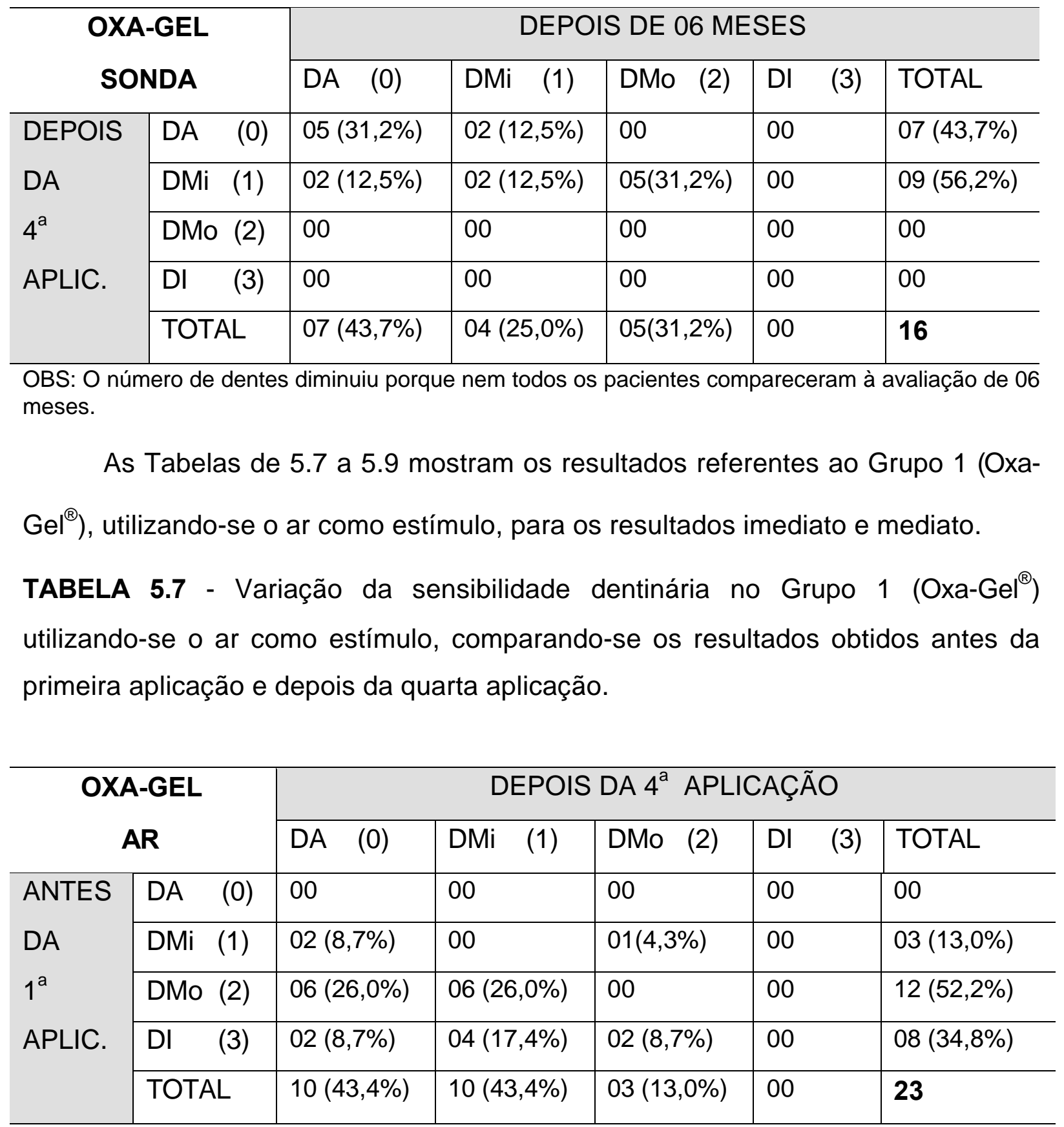


Observando-se os extremos inferior e direito dessa tabela, tem-se uma visualização clara da evolução do tratamento e a compreensão dos resultados.

Pode-se observar que, antes da primeira aplicação do Oxa-Gel ${ }^{\circledR}$, quando a sonda foi usada como estímulo, 03 dentes (13,0\%) apresentavam dor mínima, 12 $(52,1 \%)$ apresentavam dor moderada e 08 (34,7\%) dor intensa, ou seja, ocorreu uma concentração maior de dentes com dor moderada e intensa. Após a $4^{\mathrm{a}}$ aplicação, nota-se maior concentração de dentes com dor ausente (10: 43,4\%) e mínima (10: 43,4\%), enquanto que apenas 03 dentes (13,0\%) continuaram com dor moderada.

TABELA 5.8 - Variação da sensibilidade dentinária no Grupo 1 (Oxa-Gel ${ }^{\circledR}$ ) utilizando-se o ar como estímulo, comparando-se os resultados obtidos antes da primeira aplicação e depois de 06 meses.

\begin{tabular}{|c|c|c|c|c|c|c|}
\hline \multirow{2}{*}{\multicolumn{2}{|c|}{$\begin{array}{c}\text { OXA-GEL } \\
\text { AR }\end{array}$}} & \multicolumn{5}{|c|}{ DEPOIS DE 06 MESES } \\
\hline & & DA $\quad(0)$ & DMi $\quad(1)$ & DMo (2) & DI (3) & TOTAL \\
\hline \multirow{5}{*}{$\begin{array}{l}\text { ANTES } \\
\text { DA } \\
1^{a} \\
\text { APLIC. }\end{array}$} & DA $(0)$ & 00 & 00 & 00 & 00 & 00 \\
\hline & DMi (1) & 00 & $03(16,6 \%)$ & 00 & 00 & $03(16,6 \%)$ \\
\hline & DMo (2) & $01(5,5 \%)$ & $03(16,6 \%)$ & $05(27,9 \%)$ & 00 & $09(50,0 \%)$ \\
\hline & DI (3) & $02(11,1 \%)$ & $02(11,1 \%)$ & $01(5,5 \%)$ & $01(5,5 \%)$ & $06(33,3 \%)$ \\
\hline & TOTAL & $03(16,6 \%)$ & $08(44,4 \%)$ & $06(33,3 \%)$ & $01(5,5 \%)$ & 18 \\
\hline
\end{tabular}

OBS: O número de dentes diminuiu porque nem todos os pacientes compareceram à avaliação de 06 meses.

A Tabela 5.8 mostra a avaliação realizada após 06 meses, quando 18 dos 23 dentes foram reavaliados. Observa-se que, antes da primeira aplicação, 3 dentes $(16,6 \%)$ apresentavam dor mínima, 9 dentes (50,0\%), dor moderada e 6 dentes 
(33,3\%), dor intensa. Após 6 meses, 3 dentes (16,6\%) apresentavam dor ausente, 8 dentes $(44,4 \%)$, dor mínima, 6 (33,3\%), dor moderada, sendo que nenhum dente apresentou dor intensa.

TABELA 5.9 - Variação da sensibilidade dentinária no Grupo 1 (Oxa-Gel) utilizandose o ar como estímulo, comparando-se os resultados obtidos depois da quarta aplicação e depois de 06 meses.

\begin{tabular}{|c|c|c|c|c|c|c|}
\hline \multirow{2}{*}{\multicolumn{2}{|c|}{$\begin{array}{c}\text { OXA-GEL } \\
\text { AR }\end{array}$}} & \multicolumn{5}{|c|}{ DEPOIS DE 06 MESES } \\
\hline & & \multirow{2}{*}{$\begin{array}{l}\text { DA (0) } \\
03(16,7 \%)\end{array}$} & \multirow{2}{*}{$\begin{array}{l}\text { DMi (1) } \\
03(16,7 \%)\end{array}$} & \multirow{2}{*}{$\begin{array}{l}\text { DMo (2) } \\
03(16,7 \%)\end{array}$} & \multirow{2}{*}{$\begin{array}{ll}\text { DI } & \text { (3) } \\
00 & \end{array}$} & \multirow{2}{*}{$\begin{array}{l}\text { TOTAL } \\
09(50,0 \%)\end{array}$} \\
\hline DEPOIS & DA $(0)$ & & & & & \\
\hline DA & DMi (1) & 00 & $04(22,2 \%)$ & $03(16,7 \%)$ & $01(5,5 \%)$ & $08(44,5 \%)$ \\
\hline $4^{a}$ & DMo (2) & 00 & $01(5,5 \%)$ & 00 & 00 & $01(5,5 \%)$ \\
\hline \multirow[t]{2}{*}{ APLIC. } & DI (3) & 00 & 00 & 00 & 00 & 00 \\
\hline & TOTAL & $03(16,7 \%)$ & $08(44,5 \%)$ & $06(33,4 \%)$ & $01(5,5 \%)$ & 18 \\
\hline
\end{tabular}

OBS: O número de dentes diminuiu porque nem todos os pacientes compareceram à avaliação de 06 meses.

Observa-se na Tabela 5.9 que os dentes que apresentavam dor ausente (9:50,0\%) depois da $4^{a}$ aplicação, passaram a apresentar dor moderada $(6: 33,4 \%)$ e intensa (1:5,5\%), permanecendo o número de dentes com dor mínima $(8: 44,5 \%)$. Pode-se dizer que, após 6 meses, houve um aumento da hiperestesia dentinária.

As Tabelas de 5.10 a 5.12 mostram os resultados referentes ao Grupo 2 (Solução Experimental 1), utilizando-se a sonda como estímulo, para os resultados imediato e mediato. 
TABELA 5.10 - Variação da sensibilidade dentinária no Grupo 2 (Solução Experimental 1) utilizando-se a sonda como estímulo, comparando-se os resultados obtidos antes da primeira aplicação e depois da quarta aplicação.

\begin{tabular}{|c|c|c|c|c|c|c|}
\hline \multirow{2}{*}{\multicolumn{2}{|c|}{$\begin{array}{c}\text { SOL. EXP. } 1 \\
\text { SONDA }\end{array}$}} & \multicolumn{5}{|c|}{ DEPOIS DA $4^{\mathrm{a}}$ APLICAÇÃO } \\
\hline & & DA $(0)$ & DMi (1) & DMo (2) & DI (3) & TOTAL \\
\hline \multirow{5}{*}{$\begin{array}{l}\text { ANTES } \\
\text { DA } \\
1^{\mathrm{a}} \\
\text { APLIC. }\end{array}$} & $\mathrm{DA} \quad(0)$ & 00 & 00 & 00 & 00 & 00 \\
\hline & DMi (1) & $07(33,4 \%)$ & $03(14,2 \%)$ & 00 & 00 & $10(47,6 \%)$ \\
\hline & DMo (2) & 02 (9,5\%) & $06(28,6 \%)$ & 00 & 00 & $08(38,1 \%)$ \\
\hline & DI (3) & $01(4,8 \%)$ & $01(4,8 \%)$ & $01(4,8 \%)$ & 00 & $03(14,3 \%)$ \\
\hline & TOTAL & $10(47,6 \%)$ & $10(47,6 \%)$ & $01(4,8 \%)$ & 00 & 21 \\
\hline
\end{tabular}

A Tabela 5.10 demonstra que, antes da $1^{\text {a }}$ aplicação da Solução Experimental 1 utilizando-se a sonda como estímulo, 10 dentes $(47,6 \%)$ apresentavam dor mínima, 08 (38,1\%), dor moderada e 03 (14,3\%), dor intensa. Após 4 semanas de tratamento, houve um aumento no número de dentes com dor ausente $(10: 47,6 \%)$, mínima (10:47,6\%) e moderada (1:4,8\%), sendo que nenhum dente apresentou dor intensa.

Após 06 meses, foram avaliados 16 dos 21 dentes; pode-se observar na Tabela 5.11 que, antes da primeira aplicação, 6 dentes (37,5\%) apresentavam dor mínima, 7 (43,7\%), dor moderada e 3 (18,7\%), dor intensa; após 6 meses, 4 dentes $(25,0 \%)$ passaram a apresentar dor ausente, 5 dentes (31,2\%), dor mínima, 6 $(37,5 \%)$, dor moderada e somente 1 dente $(6,2 \%)$ apresentou dor intensa. 
TABELA 5.11 - Variação da sensibilidade dentinária no Grupo 2 (Solução Experimental 1) utilizando-se a sonda como estímulo, comparando-se os resultados obtidos antes da primeira aplicação e depois de 06 meses.

\begin{tabular}{|c|c|c|c|c|c|c|}
\hline \multirow{2}{*}{\multicolumn{2}{|c|}{$\begin{array}{c}\text { SOL. EXP. } 1 \\
\text { SONDA }\end{array}$}} & \multicolumn{5}{|c|}{ DEPOIS DE 06 MESES } \\
\hline & & $\mathrm{DA} \quad(0)$ & DMi (1) & DMo (2) & $\mathrm{DI} \quad(3)$ & TOTAL \\
\hline \multirow{5}{*}{$\begin{array}{l}\text { ANTES } \\
\text { DA } \\
1^{a} \\
\text { APLIC. }\end{array}$} & DA $\quad(0)$ & 00 & 00 & 00 & 00 & 00 \\
\hline & DMi (1) & $02(12,5 \%)$ & $02(12,5 \%)$ & $01(6,2 \%)$ & $01(6,2 \%)$ & $06(37,5 \%)$ \\
\hline & DMo (2) & $01(6,25 \%)$ & $02(12,5 \%)$ & $04(25,0 \%)$ & 00 & $07(43,7 \%)$ \\
\hline & (3) & $01(6,25 \%)$ & $01(6,2 \%)$ & $01(6,2 \%)$ & 00 & $03(18,7 \%)$ \\
\hline & TOTAL & $04(25,0 \%)$ & $05(31,2 \%)$ & $06(37,5 \%)$ & $01(6,2 \%)$ & 16 \\
\hline
\end{tabular}

OBS: O número de dentes diminuiu porque nem todos os pacientes compareceram à avaliação de 06 meses.

Na tabela 5.12, observa-se o número de dentes que apresentavam dor ausente (8:50,0\%), mínima (7:43,7\%) e moderada (1:6,2\%); apenas $4(25,0 \%)$ continuaram com dor ausente e 05 dentes (31,2\%) continuaram com dor mínima, enquanto que $06(37,5 \%)$ e $1(6,2 \%)$ dentes passaram a apresentar dor moderada e intensa respectivamente, representando um aumento da hiperestesia dentinária.

TABELA 5.12 - Variação da sensibilidade dentinária no Grupo 2 (Solução Experimental 1) utilizando-se a sonda como estímulo, comparando-se os resultados obtidos depois da quarta aplicação e depois de 06 meses. 


\begin{tabular}{|c|c|c|c|c|c|c|}
\hline \multirow{2}{*}{\multicolumn{2}{|c|}{$\begin{array}{c}\text { SOL. EXP. } 1 \\
\text { SONDA }\end{array}$}} & \multicolumn{5}{|c|}{ DEPOIS DE 06 MESES } \\
\hline & & \multirow{2}{*}{$\begin{array}{l}\text { DA (0) } \\
03(18,7 \%)\end{array}$} & \multirow{2}{*}{$\begin{array}{l}\text { DMi (1) } \\
03(18,7 \%)\end{array}$} & \multirow{2}{*}{$\begin{array}{l}\text { DMo (2) } \\
01(6,2 \%)\end{array}$} & \multirow{2}{*}{$\begin{array}{l}\text { DI (3) } \\
01(6,2 \%)\end{array}$} & \multirow{2}{*}{$\begin{array}{l}\text { TOTAL } \\
08(50,0 \%)\end{array}$} \\
\hline DEPOIS & DA $\quad(0)$ & & & & & \\
\hline DA & DMi (1) & $01(6,2 \%)$ & $02(12,5 \%)$ & $04(25,0 \%)$ & 00 & $07(43,7 \%)$ \\
\hline $4^{a}$ & DMo (2) & 00 & 00 & $01(6,2 \%)$ & 00 & $01(6,2 \%)$ \\
\hline \multirow[t]{2}{*}{ APLIC. } & DI (3) & 00 & 00 & 00 & 00 & 00 \\
\hline & TOTAL & $04(25,0 \%)$ & $05(31,2 \%)$ & $06(37,5 \%)$ & $01(6,2 \%)$ & 16 \\
\hline
\end{tabular}

OBS: O número de dentes diminuiu porque nem todos os pacientes compareceram à avaliação de 06 meses.

As Tabelas de 5.13 a 5.15 mostram os resultados referentes ao Grupo 2 (Solução Experimental 1), utilizando-se o ar como estímulo, para os resultados imediato e mediato respectivamente:

TABELA 5.13 - Variação da sensibilidade dentinária no Grupo 2 (Solução Experimental 1) utilizando-se o ar como estímulo, comparando-se os resultados obtidos antes da primeira aplicação e depois da quarta aplicação.

\begin{tabular}{|c|c|c|c|c|c|c|}
\hline \multirow{2}{*}{\multicolumn{2}{|c|}{$\begin{array}{c}\text { SOL. EXP. } 1 \\
\text { AR }\end{array}$}} & \multicolumn{5}{|c|}{ DEPOIS DA $4^{\mathrm{a}}$ APLICAÇÃO } \\
\hline & & $\mathrm{DA} \quad(0)$ & DMi (1) & DMo (2) & DI (3) & TOTAL \\
\hline \multirow{5}{*}{$\begin{array}{l}\text { ANTES } \\
\text { DA } \\
1^{\mathrm{a}} \\
\text { APLIC. }\end{array}$} & $\mathrm{DA} \quad(0)$ & 00 & 00 & 00 & 00 & 00 \\
\hline & DMi (1) & $03(11,5 \%)$ & $02(7,7 \%)$ & 00 & 00 & $05(19,2 \%)$ \\
\hline & DMo (2) & $08(30,7 \%)$ & $06(23,0 \%)$ & $01(3,8 \%)$ & 00 & $15(57,6 \%)$ \\
\hline & DI (3) & $03(11,5 \%)$ & $02(7,7 \%)$ & 00 & $01(3,8 \%)$ & $06(23,0 \%)$ \\
\hline & TOTAL & $14(53,8 \%)$ & $10(38,4 \%)$ & $01(3,8 \%)$ & $01(3,8 \%)$ & 26 \\
\hline
\end{tabular}


Observa-se na tabela acima que, antes da primeira aplicação, 5 dentes (19,2\%) apresentavam dor mínima, 15 (57,6\%), dor moderada e 06 (23,0\%), dor intensa. Após a $4^{a}$ aplicação, houve um aumento na concentração de dentes com dor ausente (14:53,8\%) e mínima (10:38,4\%), e uma diminuição de dentes com dor moderada $(1: 3,8 \%)$ e intensa $(1: 3,8 \%)$.

Após 6 meses, foram avaliados 19 dos 26 dentes. Na Tabela 5.14, pode-se observar que, antes da primeira aplicação, 4 dentes $(21,0 \%)$ apresentavam dor mínima, 11 dentes (57,9\%), dor moderada e 4 (21,0\%), dor intensa e, ainda, que, quando comparados aos resultados de 6 meses, 12 dentes $(63,1 \%)$ passaram a apresentar dor ausente, 6 dentes (31,6\%), dor mínima, 1 dente (5,2\%), dor moderada, e nenhum apresentou dor intensa.

TABELA 5.14 - Variação da sensibilidade dentinária no Grupo 2 (Solução Experimental 1) utilizando-se o ar como estímulo, comparando-se os resultados obtidos antes da primeira aplicação e depois de 06 meses.

\begin{tabular}{|c|c|c|c|c|c|c|}
\hline \multirow{2}{*}{\multicolumn{2}{|c|}{$\begin{array}{c}\text { SOL. EXP. } 1 \\
\text { AR }\end{array}$}} & \multicolumn{5}{|c|}{ DEPOIS DE 06 MESES } \\
\hline & & DA (0) & DMi (1) & DMo (2) & $\mathrm{DI} \quad(3)$ & TOTAL \\
\hline \multirow{5}{*}{$\begin{array}{l}\text { ANTES } \\
\text { DA } \\
1^{a} \\
\text { APLIC. }\end{array}$} & DA $\quad(0)$ & 00 & 00 & 00 & 00 & 00 \\
\hline & DMi (1) & $02(10,5 \%)$ & $01(5,2 \%)$ & $01(5,2 \%)$ & 00 & $04(21,0 \%)$ \\
\hline & DMo (2) & $06(31,6 \%)$ & $05(26,3 \%)$ & 00 & 00 & $11(57,9 \%)$ \\
\hline & DI (3) & $04(21,0 \%)$ & 00 & 00 & 00 & $04(21,0 \%)$ \\
\hline & TOTAL & $12(63,1 \%)$ & $06(31,6 \%)$ & $01(5,2 \%)$ & 00 & 19 \\
\hline
\end{tabular}

OBS: O número de dentes diminuiu porque nem todos os pacientes compareceram à avaliação de 06 meses. 
A avaliação mediata desse agente anti-hiperestésico, utilizando-se o ar como estímulo, demonstra que, após 6 meses, houve um aumento na concentração de dentes com dor ausente $(12: 63,1 \%)$, e uma diminuição no número de dentes com dor mínima (6:31,6\%), sendo que nenhum dente apresentou dor intensa.

TABELA 5.15 - Variação da sensibilidade dentinária no Grupo 2 (Solução Experimental 1) utilizando-se o ar como estímulo, comparando-se os resultados obtidos depois da quarta aplicação e depois de 06 meses.

\begin{tabular}{|c|c|c|c|c|c|c|}
\hline \multirow{2}{*}{\multicolumn{2}{|c|}{$\begin{array}{c}\text { SOL. EXP. } 1 \\
\text { AR }\end{array}$}} & \multicolumn{5}{|c|}{ DEPOIS DE 06 MESES } \\
\hline & & \multirow{2}{*}{$\begin{array}{l}\text { DA (0) } \\
08(42,1 \%)\end{array}$} & \multirow{2}{*}{\begin{tabular}{|l|} 
DMi (1) \\
$01(5,3 \%)$ \\
\end{tabular}} & \multirow{2}{*}{$\begin{array}{l}\text { DMo (2) } \\
00\end{array}$} & \multirow{2}{*}{$\begin{array}{ll}\text { DI } & (3) \\
00 & \end{array}$} & \multirow{2}{*}{$\begin{array}{l}\text { TOTAL } \\
09(47,3 \%)\end{array}$} \\
\hline DEPOIS & $\mathrm{DA} \quad(0)$ & & & & & \\
\hline DA & DMi (1) & $03(15,8 \%)$ & $04(21,0 \%)$ & $01(5,3 \%)$ & 00 & $08(42,1 \%)$ \\
\hline $4^{\mathrm{a}}$ & DMo (2) & 00 & $01(5,3 \%)$ & 00 & 00 & $01(5,3 \%)$ \\
\hline \multirow[t]{2}{*}{ APLIC. } & DI (3) & $01(5,3 \%)$ & 00 & 00 & 00 & $01(5,3 \%)$ \\
\hline & TOTAL & $12(63,1 \%)$ & $06(31,6 \%)$ & $01(5,3 \%)$ & 00 & 19 \\
\hline
\end{tabular}

OBS: O número de dentes diminuiu porque nem todos os pacientes compareceram à avaliação de 06 meses.

As Tabelas de 5.16 a 5.18 mostram os resultados referentes ao Grupo 3 (Solução Experimental 2), utilizando-se a sonda como estímulo:

TABELA 5.16 - Variação da sensibilidade dentinária no Grupo 3 (Solução Experimental 2) utilizando-se a sonda como estímulo, comparando-se os resultados obtidos antes da primeira aplicação e depois da quarta aplicação. 


\begin{tabular}{|c|c|c|c|c|c|c|}
\hline \multirow{2}{*}{\multicolumn{2}{|c|}{$\begin{array}{c}\text { SOL. EXP. } 2 \\
\text { SONDA }\end{array}$}} & \multicolumn{5}{|c|}{ DEPOIS DA $4^{\mathrm{a}}$ APLICAÇÃO } \\
\hline & & DA $(0)$ & $\mathrm{DMi} \quad(1)$ & DMo (2) & DI (3) & TOTAL \\
\hline \multirow{5}{*}{$\begin{array}{l}\text { ANTES } \\
\text { DA } \\
1^{a} \\
\text { APLIC. }\end{array}$} & DA $(0)$ & 00 & 00 & 00 & 00 & 00 \\
\hline & DMi (1) & $03(12,5 \%)$ & $03(12,5 \%)$ & 00 & 00 & $06(25,0 \%)$ \\
\hline & DMo (2) & $06(25,0 \%)$ & $05(20,8 \%)$ & $02(8,3 \%)$ & 00 & $13(54,1 \%)$ \\
\hline & DI (3) & $02(8,3 \%)$ & $02(8,3 \%)$ & $01(4,1 \%)$ & 00 & $05(20,9 \%)$ \\
\hline & TOTAL & $11(45,8 \%)$ & $10(41,6 \%)$ & $03(12,5 \%)$ & 00 & 24 \\
\hline
\end{tabular}

Quando a Solução Experimental 2 foi aplicada utilizando-se a sonda como estímulo, observa-se que, antes da $1^{a}$ aplicação, 06 dentes (25,0\%) apresentavam dor mínima, 13 dentes (54,1\%), dor moderada e 05 dentes $(20,9 \%)$, dor intensa. Após a $4^{a}$ aplicação, $11(45,8 \%)$ dentes passaram a apresentar dor ausente, 10 (41,6\%), dor mínima e 03 (12,5\%) continuaram com dor moderada.

$\mathrm{Na}$ avaliação realizada após 06 meses, 15 dos 24 dentes foram reavaliados; pode-se observar, na Tabela 5.17, que a maior concentração referia-se a dentes com dor moderada $(9: 60,0 \%)$ e intensa $(4: 26,6 \%)$, havendo somente 2 dentes $(13,3 \%)$ com dor mínima. Conforme os resultados obtidos após 6 meses, nota-se que a maior concentração passa a ser de dentes com dor ausente $(40,0 \%)$ e mínima (40,0\%), sendo que somente 3 dentes $(20,0 \%)$ continuaram a apresentar dor moderada e nenhum com dor intensa.

TABELA 5.17 - Variação da sensibilidade dentinária no Grupo 3 (Solução Experimental 2) utilizando-se a sonda como estímulo, comparando-se os resultados obtidos antes da primeira aplicação e depois de 06 meses. 


\begin{tabular}{|c|c|c|c|c|c|c|}
\hline \multirow{2}{*}{\multicolumn{2}{|c|}{$\begin{array}{c}\text { SOL. EXP. } 2 \\
\text { SONDA }\end{array}$}} & \multicolumn{5}{|c|}{ DEPOIS DE 06 MESES } \\
\hline & & $\mathrm{DA} \quad(0)$ & DMi (1) & DMo (2) & DI (3) & TOTAL \\
\hline \multirow{5}{*}{$\begin{array}{l}\text { ANTES } \\
\text { DA } \\
1^{\mathrm{a}} \\
\text { APLIC. }\end{array}$} & DA $\quad(0)$ & 00 & 00 & 00 & 00 & 00 \\
\hline & DMi (1) & $01(6,7 \%)$ & $01(6,7 \%)$ & 00 & 00 & $02(13,3 \%)$ \\
\hline & DMo (2) & $04(26,6 \%)$ & $04(26,6 \%)$ & $01(6,7 \%)$ & 00 & $09(60,0 \%)$ \\
\hline & DI (3) & $01(6,7 \%)$ & $01(6,7 \%)$ & $02(13,3 \%)$ & 00 & $04(26,6 \%)$ \\
\hline & TOTAL & $06(40,0 \%)$ & $06(40,0 \%)$ & $03(20,0 \%)$ & 00 & 15 \\
\hline
\end{tabular}

Comparando-se os resultados obtidos depois da $4^{a}$ aplicação com aqueles evidenciados após 6 meses, observa-se que esses permaneceram os mesmos, sem aumento ou diminuição da hiperestesia dentinária.

TABELA 5.18 - Variação da sensibilidade dentinária no Grupo 3 (Solução Experimental 2) utilizando-se a sonda como estímulo, comparando-se os resultados obtidos depois da quarta aplicação e depois de 06 meses.

\begin{tabular}{|c|c|c|c|c|c|c|}
\hline \multirow{2}{*}{\multicolumn{2}{|c|}{$\begin{array}{c}\text { SOL. EXP. } 2 \\
\text { SONDA }\end{array}$}} & \multicolumn{5}{|c|}{ DEPOIS DE 06 MESES } \\
\hline & & DA $(0)$ & DMi (1) & DMo (2) & DI (3) & TOTAL \\
\hline \multirow{5}{*}{$\begin{array}{l}\text { DEPOIS } \\
\text { DA } \\
4^{\mathrm{a}} \\
\text { APLIC. }\end{array}$} & $\mathrm{DA} \quad(0)$ & $04(26,6 \%)$ & $02(13,3 \%)$ & 00 & 00 & $06(40,0 \%)$ \\
\hline & DMi (1) & $01(6,6 \%)$ & $03(13,3 \%)$ & $02(13,3 \%)$ & 00 & $06(40,0 \%)$ \\
\hline & DMo (2) & $01(6,6 \%)$ & $01(6,6 \%)$ & $01(6,6 \%)$ & 00 & $03(20,0 \%)$ \\
\hline & DI (3) & 00 & 00 & 00 & 00 & 00 \\
\hline & TOTAL & $06(40,0 \%)$ & $06(40,0 \%)$ & $03(20,0 \%)$ & 00 & 15 \\
\hline
\end{tabular}

OBS: O número de dentes diminuiu porque nem todos os pacientes compareceram à avaliação de 06 meses. 
As Tabelas de 5.19 a 5.21 mostram os resultados referentes ao Grupo 3 (Solução Experimental 2), utilizando-se o ar como estímulo:

TABELA 5.19 - Variação da sensibilidade dentinária no Grupo 3 (Solução Experimental 2) utilizando-se o ar como estímulo, comparando-se os resultados obtidos antes da primeira aplicação e depois da quarta aplicação.

\begin{tabular}{|c|c|c|c|c|c|c|}
\hline \multirow{2}{*}{\multicolumn{2}{|c|}{$\begin{array}{c}\text { SOL. EXP. } 2 \\
\text { AR }\end{array}$}} & \multicolumn{5}{|c|}{ DEPOIS DA $4^{\mathrm{a}}$ APLICAÇÃO } \\
\hline & & $\mathrm{DA} \quad(0)$ & DMi (1) & DMo (2) & DI (3) & TOTAL \\
\hline \multirow{2}{*}{$\begin{array}{l}\text { ANTES } \\
\text { DA }\end{array}$} & $\begin{array}{ll}\mathrm{DA} & (0)\end{array}$ & 00 & 00 & 00 & 00 & 00 \\
\hline & DMi (1) & $03(11,1 \%)$ & $03(11,1 \%)$ & 00 & 00 & $06(22,2 \%)$ \\
\hline $1^{a}$ & DMo (2) & $09(33,3 \%)$ & $02(7,4 \%)$ & $01(3,7 \%)$ & 00 & $12(44,4 \%)$ \\
\hline \multirow[t]{2}{*}{ APLIC. } & DI (3) & $02(7,4 \%)$ & $05(18,5 \%)$ & $02(7,4 \%)$ & 00 & $09(33,3 \%)$ \\
\hline & TOTAL & $14(51,8 \%)$ & $10(37,0 \%)$ & $03(11,1 \%)$ & 00 & 27 \\
\hline
\end{tabular}

Nota-se na tabela acima que, após esse período, houve um aumento do número de dentes com ausência de dor $(14: 51,8 \%)$ quando comparado ao baseline (6:22,2\%), e uma diminuição no número de dentes com dor mínima (10:37,0\%), moderada $(3: 11,1 \%)$ e, conseqüentemente, uma diminuição de dor intensa.

TABELA 5.20 - Variação da sensibilidade dentinária no Grupo 3 (Solução Experimental 2) utilizando-se o ar como estímulo, comparando-se os resultados obtidos antes da primeira aplicação e depois de 06 meses. 


\begin{tabular}{|c|c|c|c|c|c|c|}
\hline \multirow{2}{*}{\multicolumn{2}{|c|}{$\begin{array}{c}\text { SOL. EXP. } 2 \\
\text { AR }\end{array}$}} & \multicolumn{5}{|c|}{ DEPOIS DE 06 MESES } \\
\hline & & DA $(0)$ & $\mathrm{DMi} \quad(1)$ & DMo (2) & DI (3) & TOTAL \\
\hline \multirow{5}{*}{$\begin{array}{l}\text { ANTES } \\
\text { DA } \\
1^{\text {a }} \\
\text { APLIC. }\end{array}$} & DA $(0)$ & 00 & 00 & 00 & 00 & 00 \\
\hline & $\mathrm{DMi} \quad(1)$ & $04(25,0 \%)$ & $01(6,2 \%)$ & 00 & 00 & $05(31,2 \%)$ \\
\hline & DMo (2) & $02(12,5 \%)$ & $02(12,5 \%)$ & 00 & 00 & $04(25,0 \%)$ \\
\hline & DI (3) & $03(18,7 \%)$ & 00 & $04(25,0 \%)$ & 00 & $07(43,7 \%)$ \\
\hline & TOTAL & $09(56,2 \%)$ & $03(19,7 \%)$ & $04(25,0 \%)$ & 00 & 16 \\
\hline
\end{tabular}

OBS: O número de dentes diminuiu porque nem todos os pacientes compareceram à avaliação de 06 meses.

$\mathrm{Na}$ Tabela 5.20 , observam-se os resultados mediatos obtidos quando 16 dos 27 dentes foram reavaliados. Esta tabela mostra que, antes da primeira aplicação, havia uma concentração de dentes com dor moderada e intensa (respectivamente 4: $25,0 \%$ e $7: 43,7 \%)$, havendo ainda 5 dentes $(31,2 \%)$ apresentando dor mínima. Após 6 meses, a maior concentração passou a ser de dentes com dor ausente $(9: 56,2 \%)$ e mínima $(3: 19,7 \%)$, e, ainda, 4 dentes $(25,0 \%)$ apresentando dor moderada, porém nenhum com dor intensa.

TABELA 5.21 - Variação da sensibilidade dentinária no Grupo 3 (Solução Experimental 2) utilizando-se o ar como estímulo, comparando-se os resultados obtidos depois da quarta aplicação e depois de 06 meses.

\begin{tabular}{|c|c|c|c|c|c|c|}
\hline \multirow{2}{*}{\multicolumn{2}{|c|}{$\begin{array}{c}\text { SOL. EXP. } 2 \\
\text { AR }\end{array}$}} & \multicolumn{5}{|c|}{ DEPOIS DE 06 MESES } \\
\hline & & \multirow{2}{*}{$\begin{array}{l}\text { DA (0) } \\
04(25,0 \%)\end{array}$} & \multirow{2}{*}{$\begin{array}{l}\text { DMi (1) } \\
03(18,7 \%)\end{array}$} & \multirow{2}{*}{$\begin{array}{l}\text { DMo (2) } \\
00\end{array}$} & \multirow{2}{*}{$\begin{array}{ll}\text { DI } & (3) \\
00 & \end{array}$} & \multirow{2}{*}{$\begin{array}{l}\text { TOTAL } \\
07(43,7 \%)\end{array}$} \\
\hline DEPOIS & $\begin{array}{ll}\mathrm{DA} & (0)\end{array}$ & & & & & \\
\hline DA & DMi (1) & $04(25,0 \%)$ & 00 & $03(18,7 \%)$ & 00 & $07(43,7 \%)$ \\
\hline $4^{a}$ & DMo (2) & $01(6,2 \%)$ & 00 & $01(6,2 \%)$ & 00 & $02(12,5 \%)$ \\
\hline \multirow[t]{2}{*}{ APLIC. } & (3) & 00 & 00 & 00 & 00 & 00 \\
\hline & TOTAL & $09(56,2 \%)$ & $03(18,7 \%)$ & $04(25,0 \%)$ & 00 & 16 \\
\hline
\end{tabular}


OBS: O número de dentes diminuiu porque nem todos os pacientes compareceram à avaliação de 06 meses.

Os resultados mediatos demonstram um aumento do número de dentes com dor ausente $(9: 56,2 \%)$ e moderada $(4: 25,0 \%)$ em comparação com os resultados obtidos após a $4^{\mathrm{a}}$ aplicação (7:43,7\% e 2:12,5\% respectivamente). Nota-se, ainda, uma diminuição do número de dentes com dor mínima $(3: 18,7 \%)$ comparado ao resultado mediato $(7: 43,7 \%)$.

As Tabelas de 5.22 a 5.24 mostram os resultados referentes ao Grupo 4 (Placebo), utilizando-se a sonda como estímulo:

TABELA 5.22 - Variação da sensibilidade dentinária no Grupo 4 (Placebo) utilizando-se a sonda como estímulo, comparando-se os resultados obtidos antes da primeira aplicação e depois da quarta aplicação.

\begin{tabular}{|c|c|c|c|c|c|c|}
\hline \multirow{2}{*}{\multicolumn{2}{|c|}{$\begin{array}{c}\text { PLACEBO } \\
\text { SONDA }\end{array}$}} & \multicolumn{5}{|c|}{ DEPOIS DA $4^{\mathrm{a}}$ APLICAÇÃO } \\
\hline & & $\mathrm{DA} \quad(0)$ & $\mathrm{DMi} \quad(1)$ & DMo (2) & DI (3) & TOTAL \\
\hline \multirow{5}{*}{$\begin{array}{l}\text { ANTES } \\
\text { DA } \\
1^{\mathrm{a}} \\
\text { APLIC. }\end{array}$} & $\begin{array}{ll}\mathrm{DA} & (0)\end{array}$ & 00 & 00 & 00 & 00 & 00 \\
\hline & DMi (1) & $02(14,3 \%)$ & $04(28,5 \%)$ & 00 & 00 & $06(42,8 \%)$ \\
\hline & DMo (2) & $01(7,1 \%)$ & $04(28,5 \%)$ & $01(7,1 \%)$ & 00 & $06(42,8 \%)$ \\
\hline & DI (3) & $01(7,1 \%)$ & 00 & 00 & $01(7,1 \%)$ & $02(14,3 \%)$ \\
\hline & TOTAL & $04(28,5 \%)$ & $08(57,1 \%)$ & $01(7,1 \%)$ & $01(7,1 \%)$ & 14 \\
\hline
\end{tabular}

Os resultados referentes à utilização do Placebo, tendo-se a sonda como estímulo, demonstram que, antes da primeira aplicação, 06 dentes (42,8\%) apresentavam dor mínima, o mesmo número, dor moderada e 02 (14,3\%) 
apresentavam dor intensa. Após 4 aplicações, nota-se um aumento do número de dentes com ausência de dor $(4: 28,5 \%)$ e dor mínima $(8: 57,1 \%)$, enquanto que apenas 1 dente $(7,1 \%)$ apresentou dor moderada e 1 dente $(7,1 \%)$, dor intensa.

TABELA 5.23 - Variação da sensibilidade dentinária no Grupo 4 (Placebo) utilizando-se a sonda como estímulo, comparando-se antes os resultados obtidos da primeira aplicação e depois de 06 meses.

\begin{tabular}{|c|c|c|c|c|c|c|}
\hline \multirow{2}{*}{\multicolumn{2}{|c|}{$\begin{array}{c}\text { PLACEBO } \\
\text { SONDA }\end{array}$}} & \multicolumn{5}{|c|}{ DEPOIS DE 06 MESES } \\
\hline & & \multirow{2}{*}{$\begin{array}{|ll|}\mathrm{DA} & (0) \\
00 & \end{array}$} & \multirow{2}{*}{$\begin{array}{l}\text { DMi (1) } \\
00\end{array}$} & \multirow{2}{*}{$\begin{array}{ll}\text { DMo (2) } \\
00\end{array}$} & \multirow{2}{*}{$\begin{array}{ll}\mathrm{DI} & (3) \\
00 & \end{array}$} & \multirow{2}{*}{$\begin{array}{l}\text { TOTAL } \\
00\end{array}$} \\
\hline ANTES & $\begin{array}{ll}\mathrm{DA} & (0)\end{array}$ & & & & & \\
\hline DA & DMi (1) & 00 & $01(12,5 \%)$ & 00 & 00 & $01(12,8 \%)$ \\
\hline $1^{a}$ & DMo (2) & 01 (12,5\%) & $02(25,0 \%)$ & 01 (12,5\%) & $01(12,5 \%)$ & $05(62,5 \%)$ \\
\hline \multirow[t]{2}{*}{ APLIC. } & DI (3) & $01(12,5 \%)$ & 00 & 01 (12,5\%) & 00 & $02(25,0 \%)$ \\
\hline & TOTAL & $02(25,0 \%)$ & 03 (37,5\%) & $02(25,0 \%)$ & $01(12,5 \%)$ & 08 \\
\hline
\end{tabular}

Dos 14 dentes que receberam o Placebo, apenas 8 foram reavaliados após 6 meses. Pode-se observar que ocorreu a maior concentração do número de dentes com dor moderada e intensa $(5: 62,5 \%$ e $2: 25,0 \%$ respectivamente), e apenas um dente apresentou dor mínima. Na avaliação mediata, nota-se que os dentes passaram a apresentar dor ausente (2:25,0\%), dor mínima (3:37.5\%), moderada $(2: 25,0 \%)$, e apenas 1 dente (12,5\%) continuou com dor intensa. 
TABELA 5.24 - Variação da sensibilidade dentinária no Grupo 4 (Placebo) utilizando-se a sonda como estímulo, comparando-se os resultados obtidos depois da quarta aplicação e depois de 06 meses.

\begin{tabular}{|c|c|c|c|c|c|c|}
\hline \multirow{2}{*}{\multicolumn{2}{|c|}{$\begin{array}{c}\text { PLACEBO } \\
\text { SONDA }\end{array}$}} & \multicolumn{5}{|c|}{ DEPOIS DE 06 MESES } \\
\hline & & $\mathrm{DA} \quad(0)$ & $\mathrm{DMi} \quad(1)$ & DMo (2) & DI (3) & TOTAL \\
\hline \multirow{5}{*}{$\begin{array}{l}\text { DEPOIS } \\
\text { DA } \\
4^{\mathrm{a}} \\
\text { APLIC. }\end{array}$} & $\begin{array}{ll}\mathrm{DA} & (0)\end{array}$ & $02(25,0 \%)$ & 00 & 00 & 00 & $02(25,0 \%)$ \\
\hline & DMi (1) & 00 & $03(37,5 \%)$ & 00 & $01(12,5 \%)$ & $04(50,0 \%)$ \\
\hline & DMo (2) & 00 & 00 & $01(12,5 \%)$ & 00 & $01(12,5 \%)$ \\
\hline & DI (3) & 00 & 00 & $01(12,5 \%)$ & 00 & $01(12,5 \%)$ \\
\hline & TOTAL & $02(25,0 \%)$ & $03(37,5 \%)$ & $02(25,0 \%)$ & $01(12,5 \%)$ & 08 \\
\hline
\end{tabular}

OBS: O número de dentes diminuiu porque nem todos os pacientes compareceram à avaliação de 06 meses.

O resultado mediato da utilização do Placebo tendo a sonda como estímulo revela que, comparando-se os resultados obtidos após a $4^{\mathrm{a}}$ aplicação com os obtidos após 6 meses, houve uma diminuição no número de dentes com dor mínima $(3: 37,5 \%)$ e um aumento no número de dentes com dor moderada (2:25,0\%), apesar da manutenção do número de dentes com dor ausente $(2: 25,0 \%)$ e intensa $(1: 12,5 \%)$.

As Tabelas de 5.25 a 5.27 mostram os resultados referentes ao Grupo 4 (Placebo) utilizando-se o ar como estímulo:

TABELA 5.25 - Variação da sensibilidade dentinária no Grupo 4 (Placebo) utilizando-se o ar como estímulo, comparando-se os resultados obtidos antes da primeira aplicação e depois da quarta aplicação. 


\begin{tabular}{|c|c|c|c|c|c|c|}
\hline \multirow{2}{*}{\multicolumn{2}{|c|}{$\begin{array}{c}\text { PLACEBO } \\
\text { AR }\end{array}$}} & \multicolumn{5}{|c|}{ DEPOIS DA $4^{\mathrm{a}}$ APLICAÇÃO } \\
\hline & & $\mathrm{DA} \quad(0)$ & DMi (1) & DMo (2) & DI (3) & TOTAL \\
\hline \multirow{5}{*}{$\begin{array}{l}\text { ANTES } \\
\text { DA } \\
1^{\text {a }} \\
\text { APLIC. }\end{array}$} & DA $\quad(0)$ & 00 & 00 & 00 & 00 & 00 \\
\hline & DMi (1) & $03(17,3 \%)$ & 00 & 00 & 00 & $03(17,6 \%)$ \\
\hline & DMo (2) & $04(23,5 \%)$ & $04(23,5 \%)$ & $01(5,8 \%)$ & 00 & $09(53,0 \%)$ \\
\hline & DI (3) & $01(5,8 \%)$ & $03(17,6 \%)$ & $01(5,8 \%)$ & 00 & $05(29,4 \%)$ \\
\hline & TOTAL & $08(47,0 \%)$ & $07(41,1 \%)$ & $02(11,7 \%)$ & 00 & 17 \\
\hline
\end{tabular}

Os resultados imediatos da aplicação do Placebo tendo o ar como estímulo demonstram que houve um aumento do número de dentes com dor ausente (8:47,0\%) e mínima $(7: 41,1 \%)$ quando comparados com o baseline, que apresentou valores $0(0,0 \%)$ e $3(17,6 \%)$, respectivamente. Notou-se também uma diminuição dos valores para dor moderada (2:11,7\% contra 9:53,0\%) e nenhum dente com dor intensa.

A comparação dos resultados obtidos antes da primeira aplicação com os observados após 6 meses, quando 11 dos 17 dentes foram reavaliados, mostra que a maior concentração, que era de dentes com dor moderada $(5: 45,5 \%)$ e intensa (4:36,3\%), passou a ser distribuída entre dor ausente (5:45,5\%), mínima (1:9,0\%) e moderada $(5: 45,5 \%)$.

TABELA 5.26 - Variação da sensibilidade dentinária no Grupo 4 (Placebo) utilizando-se o ar como estímulo, comparando-se os resultados obtidos antes da primeira aplicação e depois de 06 meses. 


\begin{tabular}{|c|c|c|c|c|c|c|}
\hline \multirow{2}{*}{\multicolumn{2}{|c|}{$\begin{array}{c}\text { PLACEBO } \\
\text { AR }\end{array}$}} & \multicolumn{5}{|c|}{ DEPOIS DE 06 MESES } \\
\hline & & \multirow{2}{*}{$\begin{array}{ll}\mathrm{DA} & (0) \\
00 & \end{array}$} & \multirow{2}{*}{$\begin{array}{ll}\text { DMi (1) } \\
00\end{array}$} & \multirow{2}{*}{$\begin{array}{ll}\text { DMo (2) } \\
00\end{array}$} & \multirow{2}{*}{$\begin{array}{ll}\text { DI } & \text { (3) } \\
00 & \end{array}$} & \multirow{2}{*}{$\begin{array}{l}\text { TOTAL } \\
00\end{array}$} \\
\hline ANTES & DA (0) & & & & & \\
\hline DA & DMi (1) & $02(18,2 \%)$ & 00 & 00 & 00 & $02(18,2 \%)$ \\
\hline $1^{a}$ & DMo (2) & $03(27,2 \%)$ & 00 & $02(18,2 \%)$ & 00 & $05(45,5 \%)$ \\
\hline \multirow[t]{2}{*}{ APLIC. } & DI (3) & 00 & $01(9,0 \%)$ & $03(27,2 \%)$ & 00 & $04(36,3 \%)$ \\
\hline & TOTAL & $05(45,5 \%)$ & $01(9,0 \%)$ & $05(45,5 \%)$ & 00 & 11 \\
\hline
\end{tabular}

OBS: O número de dentes diminuiu porque nem todos os pacientes compareceram à avaliação de 06 meses.

TABELA 5.27 - Variação da sensibilidade dentinária no Grupo 4 (Placebo) utilizando-se o ar como estímulo, comparando-se os resultados obtidos depois da quarta aplicação e depois de 06 meses.

\begin{tabular}{|c|c|c|c|c|c|c|}
\hline \multirow{2}{*}{\multicolumn{2}{|c|}{$\begin{array}{c}\text { PLACEBO } \\
\text { AR }\end{array}$}} & \multicolumn{5}{|c|}{ DEPOIS DE 06 MESES } \\
\hline & & \multirow{2}{*}{$\begin{array}{l}\text { DA }(0) \\
04(36,3 \%)\end{array}$} & \multirow{2}{*}{$\begin{array}{ll}\text { DMi (1) } \\
00\end{array}$} & \multirow{2}{*}{$\begin{array}{l}\text { DMo (2) } \\
00\end{array}$} & \multirow{2}{*}{$\begin{array}{ll}\text { DI } & \text { (3) } \\
00 & \end{array}$} & \multirow{2}{*}{$\frac{\text { TOTAL }}{04(36,3 \%)}$} \\
\hline DEPOIS & DA (0) & & & & & \\
\hline DA & DMi (1) & $01(9,1 \%)$ & $01(9,1 \%)$ & $04(36,3 \%)$ & 00 & 06 (54,5\%) \\
\hline $4^{\mathrm{a}}$ & DMo (2) & 00 & 00 & $01(9,1 \%)$ & 00 & $01(9,1 \%)$ \\
\hline \multirow[t]{2}{*}{ APLIC. } & (3) & 00 & 00 & 00 & 00 & 00 \\
\hline & TOTAL & $05(45,4 \%)$ & $01(9,1 \%)$ & $05(45,4 \%)$ & 00 & 11 \\
\hline
\end{tabular}

OBS: O número de dentes diminuiu porque nem todos os pacientes compareceram à avaliação de 06 meses.

Observa-se, nessa tabela, que o número de dentes com dor ausente depois da $4^{\mathrm{a}}$ aplicação (4:36,3\%) aumentou ligeiramente após 6 meses $(5: 45,4 \%)$, sendo que o número de dentes com dor mínima depois da $4^{\text {a }}$ aplicação $(4: 36,4 \%)$ diminuiu para $1(9,1 \%)$ após 6 meses. Já o número de dentes que apresentavam dor 
moderada após a $4^{\mathrm{a}}$ aplicação $(1: 9,1 \%)$ passou a ser mais representativo $(5: 45,4 \%)$ após 6 meses.

Os dados obtidos durante o tratamento estão relacionados a respostas subjetivas por parte dos pacientes tratados, de acordo com o Grau de Sensibilidade variando de 0 a 3 . Assim, para análise estatística, foram utilizados os seguintes métodos não paramétricos: teste de Kruskal-Wallis para análise dos resultados entre-grupos, ou seja, para comparação entre os quatro grupos em cada um dos períodos analisados, e teste de Friedman Two- Way ANOVA para análise dos resultados intra-grupos, ou seja, para comparação dos diferentes períodos de avaliação em cada grupo. Em ambos os testes foi adotado nível de significância de $5 \%$.

A Tabela 5.28A demonstra a comparação dos resultados entre os grupos, aplicando-se o teste de Kruskal-Wallis (valores H). Observa-se que, apesar de haver uma diferença entre os materiais, esta não foi estatisticamente significante.

TABELA 5.28 A :- Teste de Kruskal-Wallis para comparação dos resultados entre os quatro grupos.

\begin{tabular}{c|l|c|c|c}
\hline PERÍODO & ESTÍMULO & $\mathbf{n}$ & $\mathbf{H}$ & $\mathbf{p}$ \\
\hline D4 - A1 & sonda & 94 & 4,04 & $0,258^{*}$ \\
& ar & 94 & 0,47 & $0,925^{\star}$ \\
\hline D6m - A1 & sonda & 65 & 6,82 & $0,078^{*}$ \\
& ar & 65 & 4,92 & $0,178^{*}$ \\
\hline D6m - D4 & sonda & 65 & 5,45 & $0,141^{*}$ \\
& ar & 65 & 10,33 & $0,016^{\star}$ \\
\hline
\end{tabular}

* não há diferença estatisticamente significante. 
A Tabela 5.28B apresenta a distribuição dos escores médios dos resultados imediato (após 4 semanas - D4) e mediato (após 06 meses - D6m) nos diferentes grupos e estímulos. Uma redução significativa da hiperestesia dentinária foi observada após as quatro aplicações (resultados imediatos) de cada material em comparação com os resultados obtidos antes da primeira aplicação, para todos os materiais e independente do estímulo aplicado. Entretanto, essa diminuição não foi estatisticamente significante quando a sonda foi utilizada como estímulo no Grupo 4 (Placebo).

Esses resultados prevaleceram depois de 6 meses, quando apenas o Grupo 2 (com estímulo sonda) apresentou redução da hiperestesia, embora estatisticamente não diferente do baseline, e o Grupo 4, quando a sonda foi utilizada como estímulo, permaneceu não efetivo em comparação com o período controle. A comparação entre os resultados obtidos após 6 meses e aqueles alcançados ao término do tratamento (após 4 aplicações) mostrou uma tendência ao retorno da hiperestesia, porém em níveis de significância estatística apenas para o Grupo 1 (com estímulo ar) e para o Grupo 2 (com estímulo sonda). 
TABELA 5.28 B:- Escores médios dos resultados Imediato e Mediato para os diferentes grupos e estímulos (Teste de Friedman two way ANOVA).

\begin{tabular}{|c|c|c|c|c|c|c|c|}
\hline \multicolumn{8}{|c|}{ ESCORES MÉDIOS / DESVIO PADRÃO } \\
\hline MATERIAL & ESTÍMULO & $\begin{array}{c}\text { A1 } \\
(n=94)\end{array}$ & $\begin{array}{c}\text { D4 } \\
(n=94)\end{array}$ & $\begin{array}{c}D 6 m \\
(n=65)\end{array}$ & $\begin{array}{l}\text { D4 - A1 } \\
(n=94)\end{array}$ & $\begin{array}{c}\text { D6m - A1 } \\
(n=65)\end{array}$ & $\begin{array}{c}\text { D6m - D4 } \\
(\mathrm{n}=65)\end{array}$ \\
\hline GRUPO 1 & SONDA & $1,43(0,94)$ & $0,52(0,51)$ & $0,83(0,86)$ & $-0,91^{*}$ & $-0,61^{*}$ & 0,27 \\
\hline$\left(\right.$ Oxa-Gel $\left.{ }^{\circledR}\right)$ & AR & $2,22(0,67)$ & $0,70(0,70)$ & $1,27(0,82)$ & $-1,52^{*}$ & $-0,88^{*}$ & $0,72^{*}$ \\
\hline GRUPO 2 & SONDA & $1,30(0,95)$ & $0,48(0,57)$ & $1,05(0,94)$ & $-0,82^{*}$ & $-0,40$ & $0,60^{*}$ \\
\hline (Sol. Exp. 1) & AR & $1,96(0,75)$ & $0,55(0,75)$ & $0,40(0,59)$ & $-1,41^{*}$ & $-1,50^{*}$ & $-0,25$ \\
\hline GRUPO 3 & SONDA & $1,74(0,90)$ & $0,59(0,69)$ & $0,75(0,77)$ & $-1,15^{*}$ & $-1,31^{*}$ & 0,00 \\
\hline (Sol. Exp. 2) & AR & $2,11(0,75)$ & $0,59(0,69)$ & $0,68(0,87)$ & $-1,52^{*}$ & $-1,43^{*}$ & $-0,00$ \\
\hline GRUPO 4 & SONDA & $1,41(0,93)$ & $0,76(0,83)$ & $0,90(1,0)$ & $-0,65$ & $-0,63$ & 0,09 \\
\hline (Placebo) & AR & $2,12(0,69)$ & $0,65(0,70)$ & $1,00(1,0)$ & $-1,47^{*}$ & $-1,18^{*}$ & 0,27 \\
\hline
\end{tabular}

* diferença estatisticamente significante com $p<0,05$. 
6 DISCUSSÃO 


\section{DISCUSSÃo}

\subsection{CONSIDERAÇÕES GERAIS}

Muitos são os tratamentos para a hiperestesia dentinária que, devido a diferentes formas de avaliação, favorecem a ocorrência de resultados conflitantes obtidos com a utilização de um mesmo agente ${ }^{62}$. Os fatores envolvidos em estudos clínicos que visam a avaliar agentes para a redução da hiperestesia dentinária são diversos, desde o estímulo utilizado até o modo de mensurar a resposta. Em vista disso, tornou-se necessário formular normas ou recomendações específicas para avaliar agentes que reduzam a hiperestesia dentinária, as quais foram avalizadas em novembro de 1984 pelo Comitê de Hipersensibilidade Dentinária do Conselho em Terapêutica Dental da American Dental Association (ADA) ${ }^{2}$.

A eficácia de cada agente está associada a um estudo clínico bem conduzido, que tenha o compromisso de medir clínica e estatisticamente a redução da dor após o tratamento. Esse efeito redutor deve ser comparado com os efeitos de um placebo As normas que devem ser seguidas em estudos de hiperestesia dentinária são:

- os dados da experiência devem ser quantificáveis e reproduzíveis;

- uma avaliação crítica deve ser feita para todas as respostas subjetivas. O início da resposta deve ser estabelecido, de preferência medido, e correlacionado a uma intensidade clinicamente definida;

- a relação entre o estímulo e a área definida da hiperestesia deve ser estabelecida por estudo clínico controlado; 
- se mais de um estímulo for usado, esse estímulo deve, então, ser reproduzível e a interferência entre eles deve ser mínima;

- deve ser usada uma análise estatística apropriada, de acordo com o desenho experimental.

Diante dessas considerações e a partir da revisão da literatura, a discussão do presente trabalho foi assim dividida:

\subsection{DISCUSSÃO DA METODOLOGIA}

\section{Seleção dos pacientes e dos dentes}

Uma importante etapa relacionada ao estudo clínico da hiperestesia dentinária é a seleção dos pacientes e dos dentes, a qual, segundo alguns autores ${ }^{15,46,81,31}$ deve ser realizada com base em critérios.

O primeiro critério de seleção do paciente foi que o mesmo apresentasse como queixa principal sensibilidade na região cervical de dentes anteriores e/ou posteriores, com ou sem lesões cervicais não cariosas. Esses pacientes, em sua maioria, relataram que existia sensibilidade ao escovar os dentes, ao tomar água gelada e ao falar. Era um desconforto presente em seu dia-a-dia. Dentre esses pacientes, foram selecionados aqueles que manifestaram interesse pelo tratamento e que concordaram com a metodologia a ser utilizada, dando-se preferência aos pacientes, funcionários e alunos da própria Faculdade de Odontologia e residentes em Bauru, para facilitar o contato e o retorno dos mesmos para o tratamento e avaliações posteriores. 
Outros aspectos fundamentais foram observados com relação à saúde geral e bucal dos pacientes. Estes deveriam apresentar condições de saúde sistêmica e psicológica dentro da normalidade, a fim de que não houvesse interferência nos resultados e no andamento da investigação. A condição bucal do paciente deveria permitir um diagnóstico correto da hiperestesia dentinária, sem a interferência de sinais e sintomas decorrentes de áreas próximas aos dentes incluídos na pesquisa.

A determinação dos padrões de higiene bucal dos pacientes foi determinada de acordo com a classificação de SANGNES; GJERMO ${ }^{84}$, em 1976, em bom, ruim e regular. Tal classificação foi considerada sem, no entanto, utilizar-se qualquer tipo de evidenciador de placa bacteriana, para evitar que o paciente, sabendo que seria examinado pelo cirurgião-dentista, pudesse ter melhorado sua escovação naquela ocasião, mascarando, assim, a realidade ${ }^{101}$. Desse modo, somente a visualização da ausência de cálculo e placa, da saúde gengival e do número de restaurações presentes foram os requisitos suficientes para a seleção do paciente, nesta primeira etapa.

A higienização tem fundamental importância, pois a presença de placa bacteriana visível, de cálculo ou de ambos poderia influenciar nos resultados do tratamento. Os pacientes com exposição da superfície radicular e inadequado controle de placa são mais predispostos à hiperestesia dentinária ${ }^{102,101}$. Segundo TROWBRIDGE; SILVER ${ }^{97}$, em 1990, a saliva contém íons cálcio e fosfato capazes de contribuir para a formação de depósitos minerais no interior do túbulos dentinários. A presença de placa bacteriana poderia interferir neste processo porque as bactérias da placa, através da produção de ácido, são capazes de dissolver qualquer mineral precipitado, causando a abertura dos túbulos dentinários. Por outro 
lado, a presença de cálculo poderia causar a oclusão dos túbulos dentinários, diminuindo a condutibilidade hidráulica da dentina e alterando os padrões de hiperestesia.

Durante o tratamento, ou mesmo na primeira consulta, nenhuma orientação quanto à higiene e fisioterapia bucal foi dada ao paciente, e tampouco nenhuma restrição quanto à ingestão de alimentos ou bebidas ácidas, a fim de que o paciente não modificasse os seus hábitos, o que poderia influenciar sobremaneira os resultados. Isso foi feito porque se pretendia, com o tratamento da hiperestesia, devolver ao paciente uma situação de conforto durante a prática diária dos hábitos de escovação e alimentação.

A hiperestesia dentinária pode ocorrer em qualquer dente; porém, a maioria dos estudos de incidência e prevalência, como os de ORCHARDSON; COLLINS ${ }^{63}$, em 1987, COLLAERT; FISCHER ${ }^{16}$, em 1991, AZEVEDO5; em 1994; SOBRAL; CARVALHO; GARONE NETO ${ }^{93}$, em 1995, aponta o canino e os pré-molares como os mais comuns, ocorrendo a hiperestesia dentinária, quase que invariavelmente, na face vestibular. Com base nesses estudos, foram selecionados para esta avaliação dentes caninos e pré-molares, nos quais as lesões cervicais não cariosas são mais comumente encontradas.

Estudos clínicos como os de KAUFMAN; KLEINBERG ${ }^{46}$, em 1994 e RIMONDINI; BARONI; CARRASSI ${ }^{81}$, em 1995, determinaram como condições básicas para a seleção dos pacientes, além das condições de saúde física e psicológica e ausência de placa bacteriana visível ou alteração gengival, a não utilização anterior de agentes anti-hiperestésicos pelo período de no mínimo seis meses, a presença de dentina exposta causada por abrasão e/ou recessão gengival, 
a ausência de cáries, restaurações e de esmalte trincado. Assim, os dentes selecionados não apresentavam cáries, trincas ou fraturas, restaurações extensas ou insatisfatórias, prótese ou aparelhos de contenção e forças oclusais anormais incidindo sobre os mesmos. Selecionados os dentes, foram realizados anamnese, exames clínico e, quando necessário, o radiográfico, para compor o diagnóstico diferencial da dor, já que existem muitas situações clínicas cujos sintomas podem ser confundidos com hiperestesia dentinária; entre estas incluem-se síndrome do dente trincado, restaurações fraturadas, cárie dental, sensibilidade pós-operatória, hipoplasia de esmalte, dentes em hiperfunção e, ainda, a abertura congênita da junção cemento-esmalte e2,97,7. $^{20}$

Dentes com problemas periodontais, como bolsas e mobilidade, e trauma oclusal acentuado foram descartados, pois poderia ocorrer a necessidade de cirurgia periodontal ou mesmo exodontia no decorrer do tratamento ${ }^{15}$.

A etiologia da lesão cervical não cariosa não foi considerada, podendo os dentes apresentarem erosão, abrasão ou abfração desde que mostrassem algum grau de sensibilidade (mínimo, moderado ou intenso). Vale ressaltar que, para estudos de hiperestesia, a uniformidade da amostra quanto ao grau de sensibilidade é importante (vide Quadro 5.1, em Resultados).

Procurou-se selecionar dentes que não tivessem sido submetidos a qualquer regime de tratamento anti-hiperestésico, no mínimo, 06 meses antes do início da pesquisa, pois, nessa circunstância, poderia ocorrer uma sobreposição de resultados do tratamento, dificultando ou alterando a interpretação dos dados. 


\section{Agentes anti-hiperestésicos avaliados}

Dentre as formas de tratamento da hiperestesia dentinária, podem ser citadas aquelas que têm influência na ação neural ou as que promovem a obliteração dos túbulos dentinários. Segundo a Teoria da Hidrodinâmica introduzida por BRÄNNSTRÖM ${ }^{10}$, em 1966, um estímulo aplicado na superfície da dentina exposta causa um rápido movimento do fluido no interior dos túbulos dentinários, ativando as terminações nervosas presentes na interface dentinopulpar. Assim, o objetivo principal do tratamento seria a obliteração ou selamento dos túbulos dentinários ${ }^{21,102,19}$.

Oxalato de potássio apresenta um grande potencial para o tratamento da hiperestesia dentinária. De acordo com PASHLEY ${ }^{66}$, em 1986 e MUZZIN; JOHNSON ${ }^{61}$, em 1989, o oxalato de potássio atua na obliteração dos túbulos dentinários através da precipitação de partículas (cristais) insolúveis e também por ação neural. O selamento dos túbulos pode ser conseguido com a aplicação tópica de oxalatos, que formam precipitados insolúveis na embocadura e no interior dos túbulos dentinários, reduzindo o fluxo do fluido e controlando a sensibilidade da dentina exposta ${ }^{35}$. Esse tipo de tratamento tem sido reportado por muitos autores, que têm utilizado o oxalato de potássio em diferentes concentrações. Os sais de potássio apresentam-se eficazes no tratamento da hiperestesia dentinária, pois atuam por despolarização das membranas das fibras nervosas bloqueando a passagem do estímulo, e não por obstrução dos túbulos dentinários pela deposição de cristais ou por diminuir a condutibilidade hidráulica da dentina ${ }^{40,55,94,73}$.

Seguindo-se as recomendações de GROSMANN ${ }^{36}$, em 1935, para a escolha do agente anti-hiperestésico ideal, pode-se observar que o oxalato de potássio 
atende às características de não ser irritante à polpa, ser de fácil aplicação, não manchar ou descolorir o dente e ser de baixo custo. A ação rápida e efeito duradouro podem ser confirmados através de estudos laboratoriais ${ }^{35,67,69}$ e clínicos $^{61,41,31,101}$, nos quais os autores observaram que o oxalato de potássio pode diminuir consideravelmente a permeabilidade da dentina e, consequentemente, a hiperestesia dentinária.

Novas formulações à base de oxalato de potássio foram sugeridas para avaliação clínica nesta dissertação devido à sua eficácia, comprovada in vitro e in vivo, e por atender às características de um agente anti-hiperestésico próximo do ideal, mantendo-se o mesmo agente ativo (oxalato de potássio monohidratado), variando-se, porém, a composição, a concentração e o pH. Até então, o oxalato não tinha atividade terapêutica, sendo de uso farmacológico apenas pela propriedade de precipitar cálcio ionizado ${ }^{100}$.

A carboximetil celulose é um espessante inerte, higroscópico, transparente de aparência acetinada, relativamente consistente, resistente a baixas temperaturas e apresenta-se sob a forma de pó ou grânulos, de coloração branca. Algumas de suas principais características químicas são o peso molecular médio de aproximadamente 700.000, pH neutro $(7,4)$ e viscosidade de 1750 cps $^{*}$.

Esse material foi utilizado para a produção dos géis do Grupo Experimental 1 e do Placebo. É também o espessante utilizado na preparação do Oxa-Gel ${ }^{\circledR}$, produto comercial usado como comparação nesse experimento (controle positivo). $\mathrm{O}$ pH originalmente neutro da carboximetil celulose promove uma ligeira elevação do $\mathrm{pH}$ da solução de oxalato de potássio monohidratado, cuja acidez é ajustada para 2,0 no momento da preparação da solução. Quando se combinam a solução e a 
carboximetil celulose, o gel obtido tem $\circ \mathrm{pH}$ elevado para 4,0. Teoricamente, a reatividade dessa formulação com a dentina é equilibrada pelo $\mathrm{pH}$ do medicamento ácido que, somada à natural afinidade do potássio com o cálcio e fosfato, promovem a precipitação de cristais insolúveis sobre a dentina e no interior dos túbulos dentinários ${ }^{66,104}$.

A literatura a respeito do carbopol é escassa. Sabe-se que é um agente espessante, com pH mais baixo e mais viscoso. É um polímero que proporciona um gel de oxalato de potássio, que mantém o pH original da solução em torno de 2,0 e uma possível maior reatividade deste com a dentina. Essa é a característica da Solução Experimental 2.

A intenção de se empregar géis para o tratamento da hiperestesia dentinária baseia-se nas vantagens clínicas de aplicação de um agente dessa natureza, uma vez que permanece estável na superfície dentinária e é de fácil visualização durante a aplicação. Por outro lado, estudos clínicos* mostram efeitos redutores da hiperestesia mais consistentes para as formulações sob a forma de gel do que para as soluções aquosas.

A influência da concentração dos agentes pode ser observada na avaliação clínica realizada por MUZZIN; JOHNSON ${ }^{61}$, em 1989, em que os melhores resultados foram obtidos com a combinação de diferentes concentrações das soluções de oxalato de potássio. As soluções com menor concentração do agente ativo promovem a formação de cristais de diâmetro menor, enquanto que a maior concentração resulta em cristais de maior diâmetro. Assim, a obliteração dos túbulos dentinários é mais efetiva, pois os cristais de diferentes tamanhos podem depositarse tanto na embocadura quanto no interior dos túbulos dentinários. 
O placebo em forma de gel, com as mesmas características dos demais agentes ativos (aspecto, viscosidade e coloração), foi utilizado para que não houvesse uma predisposição do paciente em relacionar o material com a sua efetividade.

\section{Estímulos}

Através da revisão da literatura e, em particular, dos estudos clínicos referentes ao tratamento da hiperestesia dentinária, observa-se uma variedade de metodologias empregadas, principalmente quanto ao tipo de estímulo utilizado e à mensuração da resposta.

A hiperestesia dentinária é definida como sendo uma dor exagerada proveniente da dentina exposta a estímulos do meio bucal. Os estímulos que causam a hiperestesia dentinária e que podem ser utilizados para avaliar tal condição são classificados em tácteis, térmicos, evaporativos, elétricos e químico-osmóticos. A escolha dos estímulos sonda exploradora (táctil) e jato de ar (térmico-evaporativo) foi feita com base na metodologia utilizada em avaliações clínicas e, ainda, conforme as recomendações de HOLLAND et al. ${ }^{42}$, em 1997 que, ao sugerirem o uso de dois estímulos hidrodinâmicos, indicam a sonda exploradora e 0 jato de ar por serem estes estímulos controláveis. Um outro fator de escolha foi a facilidade de acesso desses estímulos, já que o clínico utiliza estes instrumentos corriqueiramente em seu consultório. Além do mais, os pacientes relataram dor ao escovar os dentes, ao ingerirem alimentos frios e até mesmo ao falar, ou seja, frente a estímulos tácteis e térmico-evaporativos.

Segundo PASHLEY ${ }^{68}$, em 1990, SOBRAL ${ }^{92}$, em 1994, SOBRAL et al. ${ }^{91}, 1997$, 
e BERÁSTEGUI ${ }^{7}$, em 1999, a sonda exploradora constitui um método simples, rápido e efetivo no diagnóstico da hiperestesia dentinária. A padronização da avaliação em um ponto específico da lesão onde ocorre a hiperestesia é particularmente impossível e, por isso, a sonda exploradora (estímulo táctil) foi utilizada em toda a extensão da lesão, até que o paciente relatasse dor semelhante à que o fez procurar por tratamento, como nas avaliações clínicas realizadas por JENSEN; DOERING ${ }^{44}$, em 1987; ORCHARDSON; COLLINS ${ }^{63}$, em 1987; OYAMA; MATSUMOTO ${ }^{64}$, em 1991, HOLBOROW ${ }^{41}$, em 1994; PEARCE; ADDY; NEWCOMBE ${ }^{74}$, em 1994; SILVERMAN; GINGOLD; CURRO ${ }^{89}$, em 1994; PEREIRA et al. ${ }^{76}$, em 1994; ESTRELA et al..$^{24}$, em 1996 e WEST et al. ${ }^{101}$, em 1997.

Sabe-se que a compressão da dentina causa o deslocamento do fluido no interior dos túbulos dentinários ${ }^{68}$. Uma questão importante é a padronização da pressão utilizada, pois a alteração da mesma poderia gerar respostas não condizentes com a realidade. Nesta avaliação clínica, procurou-se padronizar a pressão utilizada através de treinamento, e a sonda exploradora foi, então, aplicada contra a dentina com uma pressão semelhante à utilizada no ato da escovação. Cabe salientar que as avaliações foram realizadas sempre pelo mesmo operador para garantir uma certa padronização do estímulo, conforme recomendado por HERNANDEZ et al. ${ }^{39}$, em 1972.

O estímulo evaporativo é assim denominado por causar, além da movimentação do fluido dentinário, a sua evaporação, ativando as terminações nervosas ${ }^{56}$. Os estudos clínicos relatam uma diversidade de maneiras de utilização do jato de ar e, segundo PASHLEY ${ }^{68}$, em 1990, não existe uma padronização para esse estímulo, podendo a sua aplicação variar em tempo, temperatura e distância do 
dente. JENSEN; DOERING ${ }^{44}$ e ORCHARDSON; COLLINS ${ }^{63}$, em 1987, OYAMA; MATSUMOTO ${ }^{64}$, em 1991, PEREIRA et al. ${ }^{76}$, em 1994 e ESTRELA et al. ${ }^{24}$, em 1996 utilizaram o jato de ar, embora não tivessem especificado a temperatura e o tempo de aplicação desse estímulo. PEARCE; ADDY; NEWCOMBE ${ }^{74}$, em 1994, utilizaram o jato de ar por 3 segundos, a $3 \mathrm{~mm}$ da dentina, mas não relatam a qual temperatura. SILVERMAN; GINGOLD; CURRO ${ }^{89}$, em 1994 e GILLAM et al. ${ }^{32}$, em 1996 utilizaram o jato de ar por 1 segundo à temperatura de 19 a $21^{\circ} \mathrm{C}$ ou $19^{\circ} \pm 3^{\circ} \mathrm{C}$ respectivamente. GILLAM et al. ${ }^{31}$, em 1997, utilizaram novamente o jato de ar com temperatura entre $19^{\circ}$ e $24^{\circ} \mathrm{C}$, posicionado, porém, perpendicularmente a $1 \mathrm{~cm}$ de distância do dente. Na presente avaliação clínica, o jato de ar foi utilizado em temperatura ambiente $\left( \pm 20^{\circ} \mathrm{C}\right)$ por 1 segundo, a $1 \mathrm{~cm}$ de distância do dente. A temperatura do jato de ar é importante, pois a baixa temperatura poderia atuar como estímulo térmico (frio), o que poderia modificar a resposta. Segundo $\operatorname{COX}^{19}$, em 1994, o jato de ar, apesar de não ser um estímulo quantitativo, pode ser utilizado e é válido para testes de hiperestesia.

Os estímulos devem ser aplicados de maneira que a resposta a um estímulo não interfira na resposta ao outro ${ }^{15,2}$. Durante as avaliações clínicas, notou-se que o jato de ar foi responsável pelos maiores graus de sensibilidade (moderado e intenso), e que a maioria dos dentes era sensível a este estímulo. Esta observação coincide com os resultados de ORCHARDSON; COLLINS ${ }^{63}$, de 1987, em que 109 pacientes foram avaliados utilizando-se a sonda e o ar; a maioria dos pacientes reportou que 0 jato de ar, tanto sozinho como combinado a outro estímulo, causou o maior desconforto. Autores ${ }^{46,31}$ recomendam que se utilize primeiro o estímulo que causa menor desconforto e, depois, o que causa maior desconforto, com um intervalo entre 
ambos. A interferência entre os estímulos foi evitada no presente trabalho, pois, primeiramente, foi utilizada a sonda exploradora em todos os dentes e, depois, faziase a mensuração da dor com o estímulo ar.

\section{Aplicação dos agentes anti-hiperestésicos}

Os agentes anti-hiperestésicos foram aplicados seguindo-se as recomendações do fabricante. A profilaxia com pedra-pomes e água não foi necessária em nenhuma aplicação. A não realização da profilaxia segue a recomendação do fabricante do Oxa-Ge ${ }^{\circledR}$, que salienta a eficácia desse produto nas situações em que o paciente não apresenta acúmulos grosseiros de placa ou cálculo. Essa característica constitui uma vantagem importante do produto, já que torna o procedimento de aplicação mais confortável para o paciente e não promove o risco de exacerbação da hiperestesia dentinária préviamente à aplicação dos agentes e à mensuração da resposta hiperestésica. Além disso, existe a possibilidade de que partículas minerais provenientes do meio bucal armazenadas na superfície dentinária sirvam de substrato para a reação com o oxalato, acentuando o seu potencial para a precipitação de cristais sobre a dentina exposta.

Após o isolamento relativo, a superfície dentinária foi umedecida e o excesso de água foi removido com papel absorvente para, então, aplicar-se passivamente o agente anti-hiperestésico. Esse procedimento foi realizado com base em um estudo in vitro realizado por PEREIRA; SEGALA; CARVALHO ${ }^{78}$, em 1996, onde o oxalato de potássio obteve os melhores resultados quando a dentina foi mantida úmida após a aplicação do ácido. Vale salientar que o condicionamento prévio com ácido está indicado em estudos laboratoriais de permeabilidade dentinária em que a remoção 
da smear layer é necessária para simular a máxima permeabilidade ${ }^{60}$, não sendo indicado clinicamente, pois tal procedimento poderia contribuir para a ampliação do diâmetro dos túbulos dentinários e, consequentemente, aumentar o grau de hiperestesia dentinária.

\section{Mensuração da resposta}

Os estudos de avaliação clínica de hiperestesia dentinária baseiam-se no relato do paciente e na mensuração do grau de sensibilidade, ou seja, em respostas subjetivas.

Pode-se observar, na revisão da literatura, que os métodos de avaliação do grau de sensibilidade estão fundamentados em escalas e questionários específicos, através dos quais o paciente "quantifica" a sua dor. As escalas mais comumente utilizadas são a Escala Virtual Analógica e a Escala de Medida Verbal. Na presente avaliação clínica, optou-se pela utilização da Escala de Medida Verbal, que é caracterizada por quatro graus de sensibilidade $(0,1,2$ e 3$)$, através dos quais 0 paciente avalia a intensidade de sua dor quando da utilização de cada estímulo.

Muitos autores como JENSEN; DOERING ${ }^{44}$, em 1987, OYAMA; MATSUMOTO ${ }^{64}$, em 1991, HOLBOROW ${ }^{41}$, em 1994, PEARCE; ADDY; NEWCOMBE ${ }^{74}$, em 1994, SILVERMAN; GINGOLD; CURRO ${ }^{89}$, em 1994, PEREIRA et al. ${ }^{76}$, em 1994, ESTRELA, et al. ${ }^{24}$ em 1996, em estudos de avaliação clínica, utilizaram a Escala de Medida Verbal (EMV), ao contrário de outros autores ${ }^{15}$ que afirmam que essa escala não indica com precisão o grau de sensibilidade para todos os pacientes por apresentar opções limitadas para definir a verdadeira intensidade da dor. Entretanto, a opção pela Escala de Medida Verbal na presente avaliação 
clínica foi baseada na maneira simples e direta com que essa escala define os diferentes graus de sensibilidade, entre dor ausente e intensa, sem confundir o paciente.

Em um estudo clínico realizado em 1988, HANSSON; BYE; SMITH ${ }^{38}$ compararam três diferentes escalas (Escala Visual Analógica, Escala de Medida Numérica e Escala Verbal) e um questionário específico (McGill) entre si e concluíram que existe uma forte correlação entre as três escalas, o que não ocorreu com relação ao questionário.

O quadro adiante compara as duas escalas, podendo-se observar que a Escala de Medida Verbal (EMV) é mais simples e objetiva. A Escala Visual Analógica (EVA) parece possibilitar uma aproximação maior da sensação de dor, mas pode vir a confundir o paciente devido à diversidade de opções oferecidas, as quais parecem ser muito próximas em suas definições (Quadro 6.1).

Quadro 6.1: Comparação entre as escalas EMV e EVA.

\begin{tabular}{|l|l|}
\hline Escala de Medida Verbal (EMV) & Escala Visual Analógica (EVA) \\
\hline 0 = dor ausente ou nenhum desconforto & $0=$ dor ausente \\
\hline 1 = dor mínima ou mínimo desconforto & $1=$ quase imperceptível \\
& $2=$ muito leve \\
& $3=$ leve \\
\hline $2=$ dor moderada ou médio & $4=$ moderada \\
desconforto & $5=$ levemente forte \\
\hline $3=$ dor intensa ou grande desconforto & $6=$ forte \\
por mais de 10 segundos & $7=$ intensa \\
& $8=$ muito intensa \\
& $9=$ extremamente intensa \\
& $10=$ a mais intensa dor imaginável \\
\hline
\end{tabular}




\subsection{DISCUSSÃO DOS RESULTADOS}

Devido à utilização de escores para a avaliação dos resultados, a análise estatística foi realizada através do emprego de testes não-paramétricos. Segundo KAUFMAN; KLEINBERG ${ }^{46}$, em 1994, quando o grau de sensibilidade é mensurado segundo a Escala de Medida Verbal, os dados devem ser analisados através do Teste de Kruskal-Wallis para verificar se existe diferença entre os grupos a cada tempo avaliado e o quanto esta diferença é significativa. Para avaliar a variação dentro de cada grupo, o Teste de Friedman two-way ANOVA deve ser utilizado.

Os padrões de hiperestesia foram distribuídos nas Tabelas de 5.1 a 5.27 (em Resultados) e as Tabelas de 29 a 57 (no Apêndice), as quais permitem o acompanhamento evolutivo do tratamento em todas suas etapas. Embora os dados contidos nas tabelas não tenham sido submetidos a uma análise estatística específica, tais tabelas fornecem uma interessante visão da proporcionalidade com que os elementos dentários responderam ao tratamento. Através delas, é possível observar-se o número e a porcentagem de dentes em seus diferentes grupos que apresentavam, por exemplo, dentes com dor intensa antes do tratamento, quantos desses dentes passaram a apresentar redução da hiperestesia e em que grau se encontravam após a primeira e até depois das quatro aplicações. A análise de todas essas tabelas permite estabelecer a trajetória do tratamento dos dentes dentro de cada padrão de hiperestesia dentinária e, ao mesmo tempo, comparar o efeito dos materiais entre si. Por essas tabelas, pode-se ver, então, que os materiais, de um modo geral, demonstram um efeito redutor da hiperestesia dentinária logo após a primeira aplicação, o qual evoluiu ao longo das aplicações subseqüentes e 
permaneceu após 6 meses num patamar de ação anti-hiperestésico ainda bastante interessante. Do ponto de vista clínico, é importante salientar que, se houver possibilidade de transposição dos padrões de hiperestesia moderada e intensa para mínima e ausente, ter-se-á alcançado um resultado clínico bastante positivo. Observa-se também que em alguns dentes os padrões de hiperestesia oscilam de mais alto para mais baixo e de mais baixo para mais alto, até se estabilizarem nos patamares definitivos ao final das quatro aplicações. Cabe aqui ressaltar que, na presente pesquisa, adotou-se o uso de quatro aplicações dos materiais, sendo uma a cada sete dias, por ser essa a média de aplicações avaliadas e consideradas efetivas para o tratamento da hiperestesia dentinária ${ }^{61,18,48,41,74,89,76,24,12}$.

No presente estudo, a avaliação imediata dos resultados (Tabela 5.28B) demonstrou que todas as formulações contendo oxalato de potássio (Oxa-Gel ${ }^{\circledR}$, Solução Experimental 1 e Solução Experimental 2) causaram uma redução estatisticamente significante $(p<0,05)$ da hiperestesia dentinária após quatro aplicações.

O oxalato de potássio, como já se salientou, é um agente anti-hiperestésico com eficácia comprovada em inúmeros estudos laboratoriais ${ }^{35,69,72}$ e clínicos ${ }^{61,18,76}$. Esse agente anti-hiperestésico pode atuar tanto por despolarização das terminações nervosas (ação neural) ${ }^{55}$, como também pela obliteração dos túbulos dentinários. Essas teorias explicam, respectivamente, os efeitos a curto e longo prazo do oxalato de potássio.

O alívio imediato ou a curto prazo da hiperestesia dentinária pode ser atribuído à ação neural do oxalato de potássio, em que uma alta concentração de potássio, aplicada topicamente, pode aumentar a concentração extracelular de 
potássio ao redor da inervação localizada nas regiões mais profundas da dentina e periferia da polpa a níveis suficientes para inativar terminações nervosas da polpa nos túbulos. Entretanto, o aumento localizado da concentração de potássio é passageiro, e a concentração será diminuída à medida que aumenta a velocidade do fluido dentinário ou a permeabilidade da barreira entre o túbulo e a polpa, causando sua despolarização ${ }^{55,94}$.

Uma outra explicação seria a própria obliteração dos túbulos dentinários, visto que PASHLEY; ANDRINGA; EICHMILLER ${ }^{71}$, em 1991, concluíram que a formação de cristais de oxalato de cálcio ocorre 30 segundos após a aplicação de soluções à base de oxalato, diminuindo a permeabilidade dentinária; e, ainda, quando essas soluções foram aplicadas por 60 segundos, mostraram-se ainda mais eficazes. No presente estudo, os agentes anti-hiperestésicos foram aplicados por 3 minutos, conforme determinado pelo fabricante $\left(\mathrm{Oxa}-\mathrm{Ge} \mathrm{l}^{\circledR}\right)$, um tempo suficiente para a formação dos cristais.

Observando a tendência evolutiva do tratamento com os diferentes agentes anti-hiperestésicos, a ação a curto prazo pode ser verificada, pois os resultados demonstram uma sutil diminuição da concentração de dentes com dor intensa e moderada logo após as primeiras aplicações, podendo esse fato ser atribuído à ação neural do oxalato de potássio.

Os resultados imediatos (após as quatro aplicações) demonstraram também uma diminuição estatisticamente significante da hiperestesia dentinária quando da aplicação do placebo, embora esta diminuição não tenha sido estatisticamente significante quando a sonda foi utilizada como estímulo. Tal resultado pode ser atribuído ao denominado "efeito placebo". Em estudos de hiperestesia dentinária, o 
placebo tem apresentado índices de sucesso de 20 a $45 \%{ }^{39}$. Sendo o placebo composto de ingredientes inertes, como a água e a carboximetil celulose, e com pH neutro, os resultados podem ser atribuídos ao fato de o paciente estar participando de um trabalho científico de pós-graduação, realizado dentro de uma faculdade, com o propósito de avaliar um tratamento específico para sua condição clínica. Em outras palavras, essa circunstância pode aumentar sua confiança, diminuir sua ansiedade e o efeito pode ser altamente positivo ${ }^{18,99}$. Segundo TROWBRIDGE; SILVER ${ }^{97}$, em 1990, o "efeito placebo" é decorrente de interações fisiológicas e psicológicas, sendo o relacionamento entre o paciente e o profissional o principal fator de resposta positiva ao placebo. Além disso, um comportamento emocional positivo e motivado pode ativar o sistema central de inibição da dor do organismo, o qual controla o estímulo doloroso da periferia através da liberação de endorfinas pelo sistema nervoso central. Em estudos de hiperestesia dentinária, a confiança no profissional e o desejo de obter alívio contribuem, sem dúvida, para o "efeito placebo".

Um outro fator que pode ter ocorrido e influenciado na interpretação dos resultados obtidos com o placebo seria o denominado "efeito Hawthorne", descrito por WEST et al. ${ }^{101}$, em 1997. Segundo estes autores, esse efeito é uma resposta a procedimentos não interventivos, como o exame clínico. Os pacientes, ao participarem de um estudo clínico, tornam-se mais criteriosos quanto à sua higienização bucal durante este período, pois são freqüentemente examinados pelo cirurgião dentista. A melhora, mesmo que inconsciente, no padrão de higiene bucal pode facilitar o acesso da saliva aos túbulos dentinários e favorecer a obliteração dos túbulos pela deposição de cálcio, fosfato e proteínas da saliva. Além disso, como já mencionado, a placa bacteriana, através da liberação de ácidos, pode ser um fator 
responsável pela hiperestesia dentinária, e a melhora da higienização pode diminuir o grau de hiperestesia.

Resultados semelhantes relacionados ao efeito placebo foram encontrados em muitos trabalhos clínicos como os de COOLEY; SANDOVAL ${ }^{18}$, em 1989, HOLBOROW ${ }^{41}$, em 1994, PEREIRA et al. ${ }^{76}$, em 1994 e ESTRELA et al. ${ }^{24}, 1996$.

Quanto ao surpreendente efeito do placebo observado no presente trabalho, pode-se especular, além do já relatado na literatura, que as características de aplicação dos géis podem ter exacerbado o efeito dos anti-hiperestésicos no momento das aplicações. Como foi relatado no capítulo Material e Método, os géis foram aplicados passivamente na superfície dentinária por 3 minutos e, após esse período, o excesso foi removido com bastonetes de algodão. Essa limpeza superficial e o teste com o ar realizado logo após poderiam acentuar a impactação de partículas na embocadura e no interior dos túbulos dentinários, reduzindo a movimentação hidráulica intratubular, responsável pela menor resposta sensorial a este estímulo quando comparado com a sonda. Esta, por sua vez, pode desobstruir mecanicamente a embocadura dos túbulos durante as avaliações realizadas imediatamente após as aplicações.

Um estudo paralelo*, ainda não publicado, em que os mesmos agentes foram empregados em testes de permeabilidade in vitro, demonstraram um determinado grau de redução da filtração de água deionizada através da dentina quando o mesmo placebo utilizado no presente estudo foi empregado.

Embora se tenha tido a preocupação de selecionar pacientes sem traumas oclusais visíveis, não se descarta a possibilidade de que pacientes com as características descritas acima tenham sofrido um ajuste natural da oclusão e, com 
isso, ocorreu a redução da hiperestesia ${ }^{30}$. Esse fato também pode ser associado aos resultados do placebo, tanto na avaliação imediata quanto nas avaliações mediatas.

A estratégia de avaliação clínica adotada nesta investigação tinha por objetivo estabelecer uma comparação entre diferentes momentos do tratamento da hiperestesia dentinária. Primeiramente, estabeleceram-se os padrões iniciais de hiperestesia pré-tratamento e, em seguida, fez-se uma comparação com os efeitos proporcionados pelos agentes estudados após as quatro aplicações, conforme se discutiu até aqui. Os dados obtidos nessa primeira etapa da investigação foram denominados resultados imediatos. A partir desse momento, duas possibilidades de acompanhamento se apresentaram e foram julgadas interessantes para registro: a comparação do estado clínico do paciente com relação à hiperestesia no baseline e o resultado do tratamento após sete meses; e a comparação dos resultados imediatos (após as quatro aplicações) com os resultados obtidos após seis meses. A primeira situação estabelece os efeitos do tratamento propriamente dito e a segunda determina a durabilidade do efeito do tratamento após quatro aplicações. Deve-se salientar que, após 06 meses de tratamento, avaliaram-se 70\% dos dentes tratados, uma vez que alguns pacientes não atenderam à reconvocação.

$\mathrm{Na}$ avaliação mediata, quando se compara o baseline (antes da primeira aplicação - A1) com os resultados obtidos após 6 meses (D6m), os níveis de redução da hiperestesia dentinária foram mantidos. Essa manutenção não foi estatisticamente significante quando a sonda foi utilizada como estímulo no Grupo 2 (Solução Experimental 1) e no Grupo 4 (Placebo).

A não ocorrência do aumento da hiperestesia dentinária após esse período pode ser atribuída ao efeito a longo prazo do oxalato de potássio nas diferentes 
formulações pela obliteração dos túbulos resultante da reação do oxalato de potássio com o cálcio presente na dentina ${ }^{35}$ e com o fluido dentinário, produzindo cristais insolúveis de oxalato de cálcio, que se depositam na embocadura e no interior dos túbulos dentinários ${ }^{104}$. Esses cristais de oxalato de cálcio precipitados são relativamente grandes, com aproximadamente 1 a 2 um de diâmetro ${ }^{35}$, coincidentes com o diâmetro médio dos túbulos dentinários $(0,9 \text { a 2,5um })^{29}$. Outro aspecto a ser observado é que os cristais de oxalato de cálcio são considerados insolúveis e resistentes ao condicionamento ácido, como confirmam os estudos de PASHLEY; GALLOWAY $^{69}$ em 1985, e de PASHLEY; DEPEW ${ }^{72}$, em 1986, sendo, portanto, resistentes aos fenômenos subseqüentes de solubilização que sofrem as estruturas dentárias mineralizadas no meio bucal. Estudos como os de PASHLEY; GALLOWAY ${ }^{89}$, em 1985, e PEREIRA; SEGALA; CARVALHO ${ }^{78}$, em 1996, têm mostrado que, nos ensaios in vitro, a condutibilidade hidráulica da dentina tratada com oxalato de potássio mantém-se próxima dos níveis de permeabilidade mínima após o desafio com ácido cítrico a $6 \%$. Em outras palavras, o oxalato de potássio mantém um padrão interessante de obstrução intertubular capaz de sustentar esse efeito, mesmo quando submetido a subseqüentes alterações de $\mathrm{pH}$ na superfície do dente. KNIGTH et al. ${ }^{50}$, em 1993, por outro lado, observaram que os cristais de oxalato de cálcio depositados na superfície dentinária eram facilmente removidos por um jato de água, conforme revelou o exame no microscópio eletrônico de varredura. Convém salientar que a permeabilidade da dentina é modificada pela precipitação de cristais na embocadura e no interior dos túbulos, e que só pode ser vista através da fratura dos espécimes e posterior análise no mesmo tipo de microscópio.

Assim, na avaliação mediata, o efeito duradouro do placebo pode não ser 
atribuído especificamente ao relacionamento paciente/profissional, supondo-se, então, que esse resultado seria uma conseqüência da formulação do próprio placebo, conforme discutido anteriormente.

Apesar de o placebo ser constituído de substâncias inertes (água e carboximetil celulose, com pH neutro), não se pode descartar a hipótese de que uma obliteração mecânica tenha ocorrido pelas partículas da carboximetil celulose que, segundo as especificações do fornecedor, têm peso molecular médio de aproximadamente 700.000. PASHLEY et al. ${ }^{67}$, em 1984, em estudo realizado com dentifrícios anti-hiperestésicos, atribuiu o efeito dessensibilizante do dentifrício placebo ao fato de que algumas partículas abrasivas neles contidas poderiam ser pequenas o suficiente para penetrar no interior dos túbulos dentinários e diminuir a condutibilidade hidráulica da dentina. Do mesmo modo, podemos supor que as partículas de carboximetil celulose pudessem ter ficado retidas mecanicamente na embocadura ou no interior dos túbulos dentinários.

A comparação mediata entre os resultados da quarta aplicação com os resultados obtidos após seis meses mostrou um aumento não significante dos padrões de hiperestesia, exceto para o Grupo 1, com o estímulo ar, e para o Grupo 2, com estímulo sonda (Tabela 5.28B). Esses dados mostram que os resultados obtidos após a quarta aplicação perduraram, de modo geral, até seis meses, sem que qualquer tratamento complementar tivesse sido realizado. Nesse momento, pode-se confirmar o efeito oclusivo proporcionado pelas formulações de oxalato de potássio e sugerir que, durante esse período de seis meses de observação, ocorreu o processo de obliteração fisiológica dos túbulos dentinários, inclusive para os dentes do grupo tratado com placebo. 
Ao analisar a Tabela 5.28A, que mostra as comparações entre os resultados obtidos após os diferentes períodos de tratamento, observou-se que não houve diferença estatisticamente significante entre os materiais, inclusive o placebo. As prováveis razões para essa semelhança estatística já foram anteriormente discutidas.

Diante dessas observações, o oxalato de potássio mostrou-se eficaz na diminuição da hiperestesia dentinária e pode ser utilizado para aliviar a sintomatologia até que ocorra a dessensibilização natural.

Uma hipótese ainda a ser estudada é a possibilidade de que o efeito antihiperestésico propalado pelo oxalato de potássio possa ser coadjuvado pelo material espessante, no caso a carboximetil celulose. 
7 CONCLUSÕES 


\section{CONCLUSÕES}

Da avaliação dos resultados obtidos nesta investigação clínica, pode-se concluir que:

1. as formulações à base de oxalato de potássio mostraram-se efetivas no tratamento da hiperestesia dentinária, independente do tempo de avaliação e do estímulo empregado.

2. tendência semelhante foi demonstrada pelo gel placebo, sugerindo que este agente tenha exercido algum efeito físico-químico-psicológico no controle da hiperestesia dentinária.

3. o efeito anti-hiperestésico dos agentes estudados pode prolongar-se por até seis meses do tratamento inicial.

4. houve uma tendência de respostas mais severas ao estímulo ar, se comparado com a sonda, previamente ao tratamento. Entretanto, a hiperestesia provocada pela sonda (estímulo táctil) mostrou-se mais persistente ao longo do tratamento.

5. pode-se inferir que o tratamento da hiperestesia dentinária está sujeito a variáveis clínicas não completamente controláveis, como a condição psicológica do paciente, a capacidade fisiológica de deposição de material mineralizado em nível de dentina, mudanças no padrão oclusal e a própria ação físico-química dos agentes, que podem aumentar ou reduzir o efeito anti-hiperestésico dos agentes avaliados. 
REFERÊNCIAS BIBLIOGRÁFICAS 


\section{REFERÊNCIAS BIBLIOGRÁFICAS*}

1.ABSI, E.G.; ADDY, M.; ADAMS, D. Dentine hypersensitivity. A study of the patency of dentinal tubules in sensitive and non-sensitive dentine. J. clin. Periodont., v.14, n.5, p.280-84, May 1987.

2.American Dental Association ad roc Advisory Committee on Dentinal Hypersensitivity Council on Dental Therapeutics: recommendations for evaluating agents for the reduction of dentinal hypersensitivity. J. Amer. dent. Ass., v.112, p.709-10, May 1986.

3.ADDY, M.; WEST, N. Etiology, mechanisms and management of dentine hypersensitivity. Current. Opin. Periodontol., p.71-7, 1994.

4.ASH, M. Quantification of stimuli. Endod. dent. Traumat., v.2, n.4, p.153-6, Aug. 1986.

5.AZEVEDO,V.M.N.N. Avaliação clínica de pacientes portadores de lesões dentárias cervicais não cariosas, relacionadas com alguns aspectos físicos, químicos e mecânicos da cavidade bucal. Bauru, 1994. 99p. Tese (Doutorado) - Faculdade de Odontologia de Bauru, Universidade de São Paulo.

\section{BERÁSTEGUI JIMENO, E. Características clínicas de la permeabilidad dentinaria: sensibilidad dentinaria. Disponível na Internet http://www.gbsystems.com/papers/endo/art8.htm. 18 abr. 1999.}

\footnotetext{
* Normas recomendadas para uso no âmbito da Universidade de São Paulo, com base no documento "Referências Bibliográficas: exemplos", emanado do Conselho Supervisor do Sistema Integrado de Bibliotecas da USP, em reunião de 20 de setembro de 1990.
} 
7.BISSADA, N. F. Symptomatology and clinical features of hipersensitive teeth. Arch. oral Biol., v.39, p.31s-2s, 1994. Supplement.

8.BRAMANTE, A. S.; VALE, I.S. Hipersensibilidade dentinária: etiologia e mecanismo de ação. Rev. FOB, v.4, n.1/2, p.60-70, jan./jun. 1996.

9.BRÄNNSTRÖM, M. ; ASTRÖM, A. The hidrodynamics of the dentine; its possible relationship to dentinal pain. Int. dent. J., v.22, n.2, p.219-27, 1972.

10.BRÄNNSTRÖM, M. Sensitivity of dentin. Oral Surg. v.21, n.4, p.517-26, Apr. 1966.

11.CARLSSON-MANN, L. D. Dentin hypersensitivity. Probe, v.29, n.6, p.226-7, 1995.

12.CARVALHO, Z.; DIAS, K. Avaliação da eficácia de três substâncias no tratamento da hipersensibilidade dentinária. In: ENCONTRO DO GRUPO BRASILEIRO DE PROFESSORES DE DENTÍSTICA, XII , Recife, 1999. Anais /Resumo n³2/

13.CHABANSKI, M. B. et al. Prevalence of cervical dentine sensitivity in a population of patients referred to a specialist Periodontology Departament. J. clin. Periodont., v.23, n.11, p.989-92, Nov. 1996.

14.CIANCIO, S. G. Delivery systems and clinical significance of avaiable agents for dentinal hypersensitivity. Endod. dent. Traumat., v.2, n.4, p.150-2, Aug. 1986.

15.CLARK, G. E.; TROULLOS, E.S. Designing hypersensitivity clinical studies. Dent. Clin. N. Amer., v.34, n.3, p.531-544, July 1990

16.COLLAERT, B.; FISCHER, C. Dentine hypersensitivity: a review. Endod. dent. Traumat., v.7, n.1, p.145-52, Feb. 1991. 
17.COOFEY, C.T. et al. Analysis of human dentinal fluid. Oral Surg., v.30, n.6, p.835-7, Dec. 1970.

18.COOLEY, R. L.; SANDOVAL, V.A. Effectiveness of potassium oxalate treatment on dentin hypersensitivity. Gen. Dent., v.37, n.4, p.330-3, July 1989.

19.COX, C. F. Etiology and treatment of root hypersensitivity. Amer. J. Dent., v.7, n.5, p.260-70, Oct. 1994.

20.CURRO, F. A. Tooth hypersensitivity in spectrum of pain. Dent. Clin. N. Amer., v.34, n.3, p. 429-37, July 1990.

21.DOWELL, P.; ADDY, M. Dentin hypersensitivity - a review: aetiology, symptoms and theories of pain production. J. clin. Periodont.,v.10, n.4, p.341-50, July 1983.

22.DOWELL, P.; ADDY, M.; DUMMER, P. Dentin hypersensitivity: aetiology, diferential diagnosis and management. Brit. dent. J., v.158, n.9, p.92-6, Feb. 1985.

23.DUROUX, P.; CIMASONI, G. Dentin hypersensitivities and their treatment: A review of the literature. Disponível na Internet. http;//www.ncbi.nlm.nih.gov. 04 maio 1999.

24.ESTRELA, $C$ et al. Análise da redução da dor pós-tratamento da hipersensibilidade dentinária. Revista Odontológica do Brasil CentralROBRAC, v.6, n.17, p.04-9, 1996.

25.ETTINGER, R. L.; HAND, J. S. Factors influencing the future need for treatment of root surfaces. Amer. J. Dent., v.7, n.5, p.255-60, Oct. 1994. 
26.FISCHER, C.; FISCHER, R. G.; WENNBERG, A. Prevalence and distribuition of cervical dentine hypersensitivity in a population in Rio de Janeiro, Brazil. J. Dent., v.20, n.5, p.272-76, Oct. 1992.

27.FRANK, R. M. Attachment sites between the odontoblast process and the intradental nerve fibre. Arch. oral Biol., v.13, n.2, p.833-4, July/Dec. 1968.

28.GANGAROSA, L. P. Current strategies for dentist-applied treatment in the management of hypersensitive dentin. Arch. oral. Biol., v.39, p. 101s-06s., 1994. Supplement.

29.GARBEROGLIO, R.; BRÄNNSTRÖM, M. Scanning eletron microscope investigation of human dentinal tubules . Arch. oral. Biol., v.21, n.6, p.355-62, June 1976.

30.GARONE FILHO, W. Lesões cervicais e hipersensibilidade dentinária. In: TODESCAN, F. F.; BOTTINO, M. A. Atualização na clínica odontológica. São Paulo, Artes Médicas, 1996. Cap.3, p. 35-75.

31.GILLAM, D. G. et al. Comparision of two desensitizing agents for the treatment of cervical dentine sensitivity. Endod. dent. Traumat., v.13, n.1, p.36-9, Feb.1997.

32.GILLAM, D. G. et al. Efficacy of a potassium nitrate mounthwash in alleviating cervical dentine sensitivity (CDS). J. clin. Periodont., v.23, n.11, p.993-7, Nov. 1996. 
33.GILLAM, D. G.; BULMAN, J. S.; NEWMAN, H. N. A pilot assessment of alternative methods of quantifying dental pain with particular reference to dentine hypersensitivity. Community dent. HIth., v.14, n.2, p.92-6, June 1997.

34.GILLAM, D. G.; NEWMAN, H. N. Assessment of pain in cervical dentinal sensitivity studies. J. clin. Periodont., v.20, n.6, p.383-94, July 1993.

35.GRENHILL, J. D.; PASHLEY, D. H. The effects of desensitizing agents on the hidraulic condutance of human dentin in vitro. J. dent. Res., v.60, n.3, p.68698, March 1981.

36.GROSSMAN, L.I. A systematic method for the treatment of hypersensitive dentin. J. Amer. dent. Ass., v.22, p.592-602, Apr. 1935.

37.GYSI, A. An attempt to explain the sensitiveness of dentine. Brit. dent. Res., v.43, p.865-68, 1900 apud COX, C.F. Etiology and treatment of root hypersensitivity. Amer. J. Dent., v.7, n.5, p.260-70, Oct. 1994.

38.HANSSON, R. E.; BYE, F.L.; SMITH, B. A. Four different pain rating scales used to evaluated dentin hypersensitivity. J. dent. Res., v.67, p.282, 1988. Special issue. /Abstract 1433/

39.HERNANDEZ, F. et al. Clinical study evaluating the desensitizing effect and duration of two commercially available dentifrices. J. Periodont., v.43, n.6, p.367-72, June 1972.

40.HODOSH, M. A superior desensitizer - potassium nitrate. J. Amer. dent. Ass., v.88, n.4, p.831-32, Apr. 1974. 
41.HOLBOROW, D.W. A clinical trial of a potassium oxalate system in the treatment of sensitive root surfaces. Arch. oral Biol., v.39, p.134s, 1994. Supplement.

42.HOLLAND ,G. R. et al. Guidelines for the design and conduct of clinical trials on dentine hypersensitivity. J. clin. Periodont., v.24, n.11, p.808-13, Nov. 1997.

43.JAIN, P. et al. Dentin desensitizing agents: SEM and $x$-ray microanalysis assessment. Amer. J. Dent., v.10, n.1, p.21-6, Feb. 1997.

44.JENSEN, M. E.; DOERING, J. V. A comparative study of two clinical techniques for treatment of root surfaces hypersensitivity. Gen. Dent., v.35, n.2, p.128-32, March/April 1987.

45.KANAPKA, J. A., COLUSSI, S. V. Clinical evaluation of dentinal hypersensitivity: comparision of methods. Endod. dent. Traumatol., v.2, n.4, p.157-64, Aug. 1986.

46.KAUFMAN, H.W.; KLEINBERG, I. Design and statistical aspects of the management of clinical trials to assess antihypersensitivity product efficacy. Arch. oral Biol., n.39, p.97s-100s, 1994. Supplement.

47.KEELE, K. D. The pain chart. Lancet, v.11, p.6-8, 1948 apud GILLAM, D.G.; NEWMAN, H. N. Assessment of pain in cervical dentinal sensitivity studies. J. Clin. Periodont., v.20, n.6, p.383-94, July 1993.

48.KERNS, D.G. et al. Dentinal tubule occlusion and root hypersensitivity. J. Periodont., v.62, n.7, p.421-8, July 1991.

49.KLEINBERG, I. Dentinal hypersensitivity. Part II: treatment of sensitive dentin. Comp. Cont. Educ. Dent., v.6, n.4, p.280-84, 1986. 
50.KNIGHT, N. N. et al. Hypersensitive dentin: testing of procedures for mechanical and chemical obliteration of dentinal tubuli. J. Periodont., v.64, n.5, p.366-73, May 1993.

51.KRAMMER ,I.R.H. The relationship between dentine sensitivity and movments in the contents of the dentinal tubules. Brit. dent. J., v.98, n.11, p.391-2, June 1955.

52.KRAUSER, J.T. Hypersensitive teeth. Part I: etiology. J. prosth. Dent., v.56, n.2, p.153-6, Aug. 1986.

53.KRAUSER, J.T. Hypersensitive teeth. Part II: treatment. J. prosth. Dent., v.56, n.3, p.307-11, Sep. 1986.

54.LING, T.Y.Y. et al. An investigation of potential desensitizing agents in the dentine disc model: a scanning electron microscopy study. J. oral Rehab., v.24, n.3, p.191-203, March 1997.

55.MARKOWITZ, K.; KIM, S. The effects of various ionic solutions on pulpal nerve sensitivity. J. dent. Res., v.64, p.309, 1985. Special issue. /Abstract 1213/

56.MATTHEWS, W.G.; SHOWMAN, C. D.; PASHLEY, D.H. Air blast-induced evaporative water loss from human dentin in vitro. Arch. oral Biol., v.38, n.6, p.517-23, June 1993.

57.McFALL Jr., W.T. A review of the active agents avaiable for treatment of dentinal hypersensitivity. Endod. dent. Traumat., v.2, n.4, p.141-9, Aug. 1986.

58.McGRATH, P. A. Psychological aspects of pain perception. Arch. oral Biol., v.39, p.55S-62S. 1994. Supplement. 
59.McGRATH, P. A. The measurament of human pain. Endod. dent. Traumat. v.2, n.4, p.123-74, Aug. 1986.

60.MONGIORGI, R. ; PRATI, C. Mineralogical and crystallographical study of gamacalcium oxalate on dentine surfaces in vitro. Arch. oral Biol.,v.39, p.152S. 1994. Supplement.

61.MUZZIN, K. B.; JOHNSON, R. Effects of potassium oxalate on dentin hypersensitivity in vivo. J. Periodont., v.60, n.3, p.151-8, March 1989.

62.ORCHARDSON, R. et al. Dentine hypersensitivity into the 21 st century. Arch. oral Biol., v.39, p.113S-19S, 1994. Supplement.

63.ORCHARDSON, R.; COLLINS, W. J. N. Clinical features of hypersensitive teeth. Brit. dent. J., v.162, n.7, p.253-6, April 1987.

64.OYAMA, T.; MATSUMOTO, K. A clinical and morfological study of cervical hypersensitivity. J. Endod., v.17, n.10, p.500-02, Oct. 1991.

65.PASHLEY, D. Dentin permeability and dentin sensitivity. Proc. Fin. dent. Soc., v.88, 1992. Supplement 1.

66.PASHLEY, D. et al. Dentin permeability, dentin sensitivity and treatment throught tubule occlusion. J. Endod., v.12, n.10, p.465-74, Oct. 1986.

67.PASHLEY, D. et al. Dentin permeability. Effects of desensitizing dentifrices in vitro. J. Periodont.,v.55, n.9, p.522-5, Sept. 1984.

68.PASHLEY, D. Mechanisms of dentin sensitivity. Dent. Clin. N. Amer., v.34, n.3, p.449-73, July 1990. 
69.PASHLEY, D.; GALLOWAY, S.E. The effects of oxalate treatment on the smear layer of ground surfaces of human dentine. Arch. oral Biol., v. 30, n.10, p.73137, July/Dec. 1985.

70.PASHLEY, D.H. et al. Fluid shifts across human dentine in vitro in response to hydrodinamic stimuli. Arch. oral Biol., v.41, n.11, p.1065-72, Nov. 1996.

71.PASHLEY, D.H.; ANDRINGA, H.J.; EICHMILLER, F. Effects of ferric and aluminum oxalates on dentin permeability. Amer . J. Dent., v.4, n.3, p.123-6, June 1991.

72.PASHLEY, D.H.; DEPEW, D. D. Effects of the smear layer, copalite and oxalate on microleakage. Oper. Dent., v.11, p.95-102, 1986.

73.PEACOCK, J.M.; ORCHARDSON, R. Action potential conduction block of nerves in vitro by potassium citrate, potassium tartrate and potassium oxalate. J. clin. Periodont.,v.26, n.1, p.33-7, Jan. 1999.

74.PEARCE, N. X.; ADDY, M.; NEWCOMBE, R. G. Dentine hypersensitivity: a clinical trial to compare 2 strontium desensitizing toothpastes with a conventional fluoride toothpaste. J. Periodont.., v.65, n.2, p.113-9, Feb.1994.

75.PEREIRA, J.C. et al. Improving the effect of desensitizing agents in condutance of human dentin in vitro. J. dent. Res., v.76, p. 96. 1997 /Abstract 660/

76.PEREIRA , J.C. et al. Treatment of dentinal hypersensitivity in pacients submitted to periodontal procedures. J. dent. Res., v.73, n.4, p.729, April 1994 /Abstract $54 /$ 
77.PEREIRA, J.C. Hiperestesia dentinária: Aspectos clínicos e formas de tratamento. Maxi-odonto Dentística, v.1, n.2, mar./abr. 1995. 24 p.

78.PEREIRA, J.C.; SEGALA, A.D.; CARVALHO, R.M. Improving dentine reaction with potassium oxalate: S.E.M. study. J. dent. Res., v.75, p.197.1996. Special issue /Abstract 1436/

79.PLAGMANN, H. C. et al. A clinical study comparing two higth-fluoride dentifrices for the treatment of dentinal hypersensitivity. Quintessence Int., v.28, n.6, p.403-8, June 1997.

80.RICHMOND, N. L. Dentinal hypersensitivity: recent advances in diagnosis and treatment. J. Indiana dent. Ass., v.72, n.1, p.20-2, Jan./Feb. 1993.

81.RIMONDINI, L.; BARONI, C.; CARRASSI, A. Ultrastructure of hypersensitive and non-sensitive dentine. A study on replica models. J. clin. Periodont., v.22, n.12, p.809-92, Dec. 1995.

82.ROSENTHAL, M.W. Historic review of the management of tooth hypersensitivity. Dent. Clin. N. Amer., v.34, n.3, p.403-27, July 1990.

83.ROSSI, G. Hipersensibilidad dentaria e su tratamiento. Rev. Asoc. odontol. argent., v.77, n.1, p.18-9, ene./feb. 1989.

84.SANGNES, G. GJERMO, P. Prevalence of oral soft and hard tissue lesions related to mechanical toothcleansing procedures. Community Dent. oral Epidem., v.4, n.2, p.77-83, May 1976. 
85.SANTOS SILVA, M.A.G. Repercussões bucais da doença por refluxo gastroesofágico. Bauru,1998. 234p. Tese (Doutorado) - Faculdade de Odontologia de Bauru, Universidade de São Paulo.

86.SELTZER, S. Hypothetic mechanisms for dentine sensitivity. Oral Surg., v.31, n.3, p.388-99, March 1971.

87.SENA, F.J. Dentinal permeability in assessing therapeutic agents. Dent. Clin. N. Amer., v.34, n.3, p.475- 90, July 1990.

88.SHONO, Y. et al. A new oxalate treatment for dentine tubule occlusion. Archs. Oral Biol., v.39, p.135S, 1994. Supplement.

89.SILVERMAN, G.; GINGOLD, J.; CURRO, F.A. Desensitizing effect of a potassium chloride dentifrice. Amer. J. Dent., v.7, n.1, p.9-12, Feb. 1994.

90.SIQUEIRA JR., J.F. Hipersensibilidade dentinária: visão atual dos mecanismos envolvidos e medidas terapêuticas. Rev. bras. Odont., v.51, n.6, p.55-8, nov./dez. 1994.

91.SOBRAL, M.A.P. Aspectos clínicos da etiologia da hipersensibilidade dentinária cervical e avaliação clínica de algumas técnicas de tratamento. São Paulo, 1997. 142p. Tese (Doutorado) - Faculdade de Odontologia de São Paulo, Universidade de São Paulo.

92.SOBRAL, M.A.P. Hipersensibilidade dentinária cervical: incidência, diagnóstico, causas e mecanismos da dor dentinária. Bauru, 1994. 125 p. Dissertação (Mestrado). Faculdade de Odontologia de Bauru - Universidade de São Paulo. 
93.SOBRAL, M.A.P.; CARVALHO, R.C.R.; GARONE NETTO, N. Prevalência de hipersensibilidade dentinária cervical. Rev. Odont. USP, v.9, n.3, p.177-81, jul./set. 1995.

94.STEAD, W, J.; ORCHARDSON, R.; WARREN, P.B. A mathematical model of potassium ion diffusion in dentinal tubules. Arch. oral Biol., v.41, n.7, p.67987, July 1996.

95.TARBET, W.J. et al. Clinical evaluation of a new treatment of dentinal hypersensitivity. J. Clin. Periodont., v.51, n.9, p.535-40, Sept. 1980.

96.THOMAS, H. F. The dentin-predentin complex and its permeability: anatomical overview. J. dent. Res., v.64, p.607-12, April 1985. Special issue.

97.TOWBRIDGE, H. O.; SILVER, D.R. A review of current approaches to in-office management of tooth hypersensitivity. Dent. Clin. N. Amer., v.34, n.3, p. 56181, July 1990.

98.TURNER, J. A. et al. The importance of placebo effects in pain treatment and research. Disponível na Internet. http://www.hsc.missouri.edu/ shrp/ ptwww/courses/assign/turner.html. 18 abr. 1999.

99.TURNER, J. A. Placebo effects on pain. Disponível na Internet. http://www. health-line.com/articles/h1950404.htm. 18abr. 1999.

100.WELT, L. G.; BLYTHE, W. B. Aniontes: fosfato, iodeto, fluoreto e outros aniontes. In: GOODMAN, L.G.; GILMAN, A. As bases farmacológicas da terapêutica. 3ed. Rio de Janeiro, Guanabara-Koogan, 1967. Cap. 38, p.73443. 
101.WEST, N. X. et al. Dentin hypersensitivity and the placebo response. A comparision of the effect of strontium acetate, potassium nitrate and fluoride toothpastes. J. clin. Periodont., v.24, n.3, p.209-15, April 1997.

102.WICHGERS, T.G.; EMERT, R.L. Dentin hypersensitivity. Gen. Dent., v.44, n.3, p.225-30, May/June 1996.

103.World Medical Association - Declaration of Helsinki. Recommendations guiding physicians in biomedical research involving human subjects. J. Amer. dent. Ass., v.277, n.11, p.925-6, March 1997.

104. YAMAMOTO, H. et al. Precipitation of oxalates in dog dentinal tubules in vivo. In: INTERNATIONAL CONFERENCE ON DENTIN/PULP COMPLEX AND THE INTERNATIONAL MEETING ON CLINICAL TOPICS OF DENTIN/PULP COMPLEX., Tokio, 1995. Proceedings. Toquio, Quintessence, 1995. p.27879.

105.YEATES, R. et al. A split-mouth placebo-controlled study to determine the effect of amorphous calcium phosphate in the treatment of dentine hypersensitivity. J. clin. Periodont., v.25, n.8, p.687-92, Aug. 1998. 
APÊNDICE 


\section{APÊNDICE}

\section{GRUPO 1: OXA-GEL ${ }^{\circledR}$ (AR)}

TABELA 29 - Variação da sensibilidade dentinária no Grupo 1 (Oxa-Gel $\left.{ }^{\circledR}\right)$ utilizandose 0 ar como estímulo, comparando-se os resultados obtidos antes e depois da primeira aplicação.

\begin{tabular}{|c|c|c|c|c|c|c|}
\hline \multirow{2}{*}{\multicolumn{2}{|c|}{$\begin{array}{c}\text { OXA-GEL } \\
\text { AR }\end{array}$}} & \multicolumn{5}{|c|}{ DEPOIS DA $1^{\mathrm{a}}$ APLICAÇÃO } \\
\hline & & DA $\quad(0)$ & DMi (1) & DMo (2) & DI (3) & TOTAL \\
\hline \multirow{5}{*}{$\begin{array}{l}\text { ANTES } \\
\text { DA } \\
1^{\mathrm{a}} \\
\text { APLIC. }\end{array}$} & DA $\quad(0)$ & 00 & 00 & 00 & 00 & 00 \\
\hline & DMi (1) & $01(4,3 \%)$ & $02(8,7 \%)$ & 00 & 00 & $03(13,0 \%)$ \\
\hline & DMo (2) & $01(4,3 \%)$ & $04(17,3 \%)$ & $06(26,0 \%)$ & $01(4,3 \%)$ & $12(52,2 \%)$ \\
\hline & $\mathrm{DI} \quad(3)$ & 00 & $01(4,3 \%)$ & $04(17,3 \%)$ & $03(13,0 \%)$ & $08(34,8 \%)$ \\
\hline & TOTAL & $02(8,7 \%)$ & $07(30,4 \%)$ & $10(43,4 \%)$ & $04(17,3 \%)$ & 23 \\
\hline
\end{tabular}

TABELA 30 - Variação da sensibilidade dentinária no Grupo $1\left(\right.$ Oxa-Gel $\left.{ }^{\circledR}\right)$ utilizandose o ar como estímulo, comparando-se os resultados obtidos antes da primeira aplicação e depois da segunda aplicação.

\begin{tabular}{|c|c|c|c|c|c|c|}
\hline \multirow{2}{*}{\multicolumn{2}{|c|}{$\begin{array}{c}\text { OXA-GEL } \\
\text { AR }\end{array}$}} & \multicolumn{5}{|c|}{ DEPOIS DA $2^{\mathrm{a}}$ APLICAÇÃO } \\
\hline & & \multirow{2}{*}{$\begin{array}{ll}\text { DA } & (0) \\
00 & \end{array}$} & \multirow{2}{*}{$\begin{array}{l}\text { DMi (1) } \\
00\end{array}$} & \multirow{2}{*}{$\begin{array}{ll}\text { DMo (2) } \\
00\end{array}$} & \multirow{2}{*}{$\begin{array}{ll}\text { DI } & \text { (3) } \\
00 & \end{array}$} & \multirow{2}{*}{$\begin{array}{l}\text { TOTAL } \\
00\end{array}$} \\
\hline ANTES & DA (0) & & & & & \\
\hline DA & DMi (1) & 00 & $03(13,0 \%)$ & 00 & 00 & $03(13,0 \%)$ \\
\hline $1^{a}$ & DMo (2) & $02(8,7 \%)$ & $02(8,7 \%)$ & $06(26,0 \%)$ & $02(8,7 \%)$ & $12(52,2 \%)$ \\
\hline \multirow[t]{2}{*}{ APLIC. } & (3) & $01(4,3 \%)$ & $01(4,3 \%)$ & $04(17,3 \%)$ & $02(8,7 \%)$ & $08(34,8 \%)$ \\
\hline & TOTAL & $03(13.0 \%)$ & $06(26,0 \%)$ & $10(43,4 \%)$ & $04(17,3 \%)$ & 23 \\
\hline
\end{tabular}


TABELA 31 - Variação da sensibilidade dentinária no Grupo 1 (Oxa-Gel $\left.{ }^{\circledR}\right)$ utilizandose 0 ar como estímulo, comparando-se os resultados obtidos antes da primeira aplicação e depois da terceira aplicação.

\begin{tabular}{|c|c|c|c|c|c|c|}
\hline \multirow{2}{*}{\multicolumn{2}{|c|}{$\begin{array}{c}\text { OXA-GEL } \\
\text { AR }\end{array}$}} & \multicolumn{5}{|c|}{ DEPOIS DA $3^{\mathrm{a}}$ APLICAÇÃO } \\
\hline & & $\begin{array}{ll}\text { DA } & (0)\end{array}$ & DMi (1) & DMo (2) & $\begin{array}{ll}\mathrm{DI} & \text { (3) }\end{array}$ & TOTAL \\
\hline \multirow{5}{*}{$\begin{array}{l}\text { ANTES } \\
\text { DA } \\
1^{\mathrm{a}} \\
\text { APLIC. }\end{array}$} & $\begin{array}{ll}\text { DA } & (0)\end{array}$ & 00 & 00 & 00 & 00 & 00 \\
\hline & DMi (1) & $01(4,3 \%)$ & $02(8,7 \%)$ & 00 & 00 & $03(13,0 \%)$ \\
\hline & DMo (2) & $01(4,3 \%)$ & $08(34,8 \%)$ & $03(13,0 \%)$ & 00 & $12(52,2 \%)$ \\
\hline & (3) & $01(4,3 \%)$ & $05(21,7 \%)$ & $02(8,7 \%)$ & 00 & $08(34,8 \%)$ \\
\hline & TOTAL & $03(13,0 \%)$ & $15(65,2 \%)$ & $05(21,7 \%)$ & 00 & 23 \\
\hline
\end{tabular}

\section{GRUPO 2: SOLUÇÃO EXPERIMENTAL 1 (SONDA)}

TABELA 32 - Variação da sensibilidade dentinária no Grupo 2 (Solução Experimental 1) utilizando-se a sonda como estímulo, comparando-se os resultados obtidos antes e depois da primeira aplicação.

\begin{tabular}{|c|c|c|c|c|c|c|}
\hline \multirow{2}{*}{\multicolumn{2}{|c|}{$\begin{array}{l}\text { SOL. EXP. } 1 \\
\text { SONDA }\end{array}$}} & \multicolumn{5}{|c|}{ DEPOIS DA $1^{\text {a }}$ APLICAÇÃO } \\
\hline & & \multirow{2}{*}{$\begin{array}{ll}\text { DA } & (0) \\
00 & \end{array}$} & \multirow{2}{*}{$\begin{array}{ll}\text { DMi (1) } \\
00\end{array}$} & \multirow{2}{*}{$\begin{array}{ll}\text { DMo (2) } \\
00\end{array}$} & \multirow{2}{*}{$\begin{array}{ll}\mathrm{DI} & (3) \\
00 & \end{array}$} & \multirow{2}{*}{$\begin{array}{l}\text { TOTAL } \\
00\end{array}$} \\
\hline ANTES & $\begin{array}{ll}\text { DA } & (0)\end{array}$ & & & & & \\
\hline DA & DMi (1) & $04(19,0 \%)$ & $06(28,5 \%)$ & 00 & 00 & $10(47,6 \%)$ \\
\hline $1^{a}$ & DMo (2) & $01(4,7 \%)$ & $02(9,5 \%)$ & $05(23,8 \%)$ & 00 & $08(38,1 \%)$ \\
\hline \multirow[t]{2}{*}{ APLIC. } & (3) & 00 & $02(9,5 \%)$ & 00 & $01(4,7 \%)$ & $03(14,3 \%)$ \\
\hline & TOTAL & $05(23,8 \%)$ & $10(47,6 \%)$ & $05(23,8 \%)$ & $01(4,7 \%)$ & 21 \\
\hline
\end{tabular}


TABELA 33 - Variação da sensibilidade dentinária no Grupo 2 (Solução Experimental 1) utilizando-se a sonda como estímulo, comparando-se os resultados obtidos antes da primeira aplicação e depois da segunda aplicação.

\begin{tabular}{|c|c|c|c|c|c|c|}
\hline \multirow{2}{*}{\multicolumn{2}{|c|}{$\begin{array}{c}\text { SOL. EXP. } 1 \\
\text { SONDA }\end{array}$}} & \multicolumn{5}{|c|}{ DEPOIS DA $2^{\mathrm{a}}$ APLICAÇÃO } \\
\hline & & $\begin{array}{ll}\text { DA } & (0)\end{array}$ & DMi (1) & DMo (2) & DI $\quad(3)$ & TOTAL \\
\hline \multirow{5}{*}{$\begin{array}{l}\text { ANTES } \\
\text { DA } \\
1^{\mathrm{a}} \\
\text { APLIC. }\end{array}$} & $\begin{array}{ll}\text { DA } & (0)\end{array}$ & 00 & 00 & 00 & 00 & 00 \\
\hline & DMi (1) & $04(19,0 \%)$ & $04(19,0 \%)$ & $02(9,5 \%)$ & 00 & $10(47,6 \%)$ \\
\hline & DMo (2) & $01(4,7 \%)$ & $07(33,3 \%)$ & $00(9,5 \%)$ & 00 & $08(38,1 \%)$ \\
\hline & (3) & 00 & $01(4,7 \%)$ & 02 & 00 & $03(14,3 \%)$ \\
\hline & TOTAL & $05(23,8 \%)$ & $12(57,1 \%)$ & $04(19,0 \%)$ & 00 & 21 \\
\hline
\end{tabular}

TABELA 34 - Variação da sensibilidade dentinária no Grupo 2 (Solução Experimental 1) utilizando-se a sonda como estímulo, comparando-se os resultados obtidos antes da primeira aplicação e depois da terceira aplicação.

\begin{tabular}{|c|c|c|c|c|c|c|}
\hline \multirow{2}{*}{\multicolumn{2}{|c|}{$\begin{array}{l}\text { SOL. EXP. } 1 \\
\text { SONDA }\end{array}$}} & \multicolumn{5}{|c|}{ DEPOIS DA $3^{\mathrm{a}}$ APLICAÇÃO } \\
\hline & & DA $(0)$ & DMi (1) & DMo (2) & $\begin{array}{ll}\mathrm{DI} & \text { (3) }\end{array}$ & TOTAL \\
\hline \multirow{5}{*}{$\begin{array}{l}\text { ANTES } \\
\text { DA } \\
1^{\text {a }} \\
\text { APLIC. }\end{array}$} & DA $(0)$ & 00 & 00 & 00 & 00 & 00 \\
\hline & DMi (1) & $04(19,0 \%)$ & $06(28,5 \%)$ & 00 & 00 & $10(47,6 \%)$ \\
\hline & DMo (2) & $01(4,7 \%)$ & $06(28,5 \%)$ & $01(4,7 \%)$ & 00 & $08(38,1 \%)$ \\
\hline & (3) & 00 & $03(14,3 \%)$ & 00 & 00 & $03(14,3 \%)$ \\
\hline & TOTAL & $05(23,8 \%)$ & $15(71,4 \%)$ & $01(4,7 \%)$ & 00 & 21 \\
\hline
\end{tabular}




\section{GRUPO 2: SOLUÇÃO EXPERIMENTAL 1 (AR)}

TABELA 35 - Variação da sensibilidade dentinária no Grupo 2 (Solução Experimental 1) utilizando-se o ar como estímulo, comparando-se os resultados obtidos antes e depois da primeira aplicação.

\begin{tabular}{|c|c|c|c|c|c|c|}
\hline \multirow{2}{*}{\multicolumn{2}{|c|}{$\begin{array}{c}\text { SOL. EXP. } 1 \\
\text { AR }\end{array}$}} & \multicolumn{5}{|c|}{ DEPOIS DA $1^{a}$ APLICAÇÃO } \\
\hline & & $\mathrm{DA} \quad(0)$ & DMi (1) & DMo (2) & DI (3) & TOTAL \\
\hline \multirow{5}{*}{$\begin{array}{l}\text { ANTES } \\
\text { DA } \\
1^{\mathrm{a}} \\
\text { APLIC. }\end{array}$} & $\mathrm{DA} \quad(0)$ & 00 & 00 & 00 & 00 & 00 \\
\hline & DMi (1) & $02(7,7 \%)$ & $02(7,7 \%)$ & 00 & $01(3,8 \%)$ & $05(19,2 \%)$ \\
\hline & DMo (2) & 00 & $07(27,0 \%)$ & $08(30,7 \%)$ & 00 & $15(57,6 \%)$ \\
\hline & (3) & 00 & $01(3,8 \%)$ & $03(11,5 \%)$ & $02(7,7 \%)$ & $06(23,0 \%)$ \\
\hline & TOTAL & $02(7,7 \%)$ & $10(38,4 \%)$ & $11(42,3 \%)$ & $03(11,5 \%)$ & 26 \\
\hline
\end{tabular}

TABELA 36 - Variação da sensibilidade dentinária no Grupo 2 (Solução Experimental 1) utilizando-se o ar como estímulo, comparando-se os resultados obtidos antes da primeira aplicação e depois da segunda aplicação.

\begin{tabular}{|c|c|c|c|c|c|c|}
\hline \multirow{2}{*}{\multicolumn{2}{|c|}{$\begin{array}{c}\text { SOL. EXP. } 1 \\
\text { AR }\end{array}$}} & \multicolumn{5}{|c|}{ DEPOIS DA $2^{\mathrm{a}}$ APLICAÇÃO } \\
\hline & & \multirow{2}{*}{$\begin{array}{ll}\mathrm{DA} & (0) \\
00 & \end{array}$} & \multirow{2}{*}{$\begin{array}{ll}\mathrm{DMi} \quad(1) \\
00\end{array}$} & \multirow{2}{*}{\begin{tabular}{|l|l} 
DMo (2) \\
00
\end{tabular}} & \multirow{2}{*}{\begin{tabular}{|ll} 
DI & (3) \\
00 &
\end{tabular}} & \multirow{2}{*}{$\begin{array}{l}\text { TOTAL } \\
00\end{array}$} \\
\hline ANTES & DA (0) & & & & & \\
\hline DA & DMi (1) & $02(7,7 \%)$ & $01(3,8 \%)$ & $01(3,8 \%)$ & $01(3,8 \%)$ & $05(19,2 \%)$ \\
\hline $1^{a}$ & DMo (2) & $02(7,7 \%)$ & $08(30,7 \%)$ & $05(19,2 \%)$ & 00 & $15(57,6 \%)$ \\
\hline \multirow[t]{2}{*}{ APLIC. } & (3) & 00 & $01(3,8 \%)$ & $04(15,3 \%)$ & $01(3,8 \%)$ & $06(23,0 \%)$ \\
\hline & TOTAL & $04(15,4 \%)$ & $10(38,4 \%)$ & $10(38,4 \%)$ & $02(7,7 \%)$ & 26 \\
\hline
\end{tabular}


TABELA 37 - Variação da sensibilidade dentinária no Grupo 2 (Solução Experimental 1) utilizando-se o ar como estímulo, comparando-se os resultados obtidos antes da primeira aplicação e depois da terceira aplicação.

\begin{tabular}{|c|c|c|c|c|c|c|}
\hline \multirow{2}{*}{\multicolumn{2}{|c|}{$\begin{array}{c}\text { SOL. EXP. } 1 \\
\text { AR }\end{array}$}} & \multicolumn{5}{|c|}{ DEPOIS DA $3^{\mathrm{a}}$ APLICAÇÃO } \\
\hline & & $\begin{array}{ll}\text { DA } & (0)\end{array}$ & DMi (1) & DMo (2) & $\mathrm{DI}$ & TOTAL \\
\hline \multirow{5}{*}{$\begin{array}{l}\text { ANTES } \\
\text { DA } \\
1^{\mathrm{a}} \\
\text { APLIC. }\end{array}$} & $\begin{array}{ll}\text { DA } & (0)\end{array}$ & 00 & 00 & 00 & 00 & 00 \\
\hline & DMi (1) & $03(11,5 \%)$ & $01(3,8 \%)$ & $01(3,8 \%)$ & 00 & $05(19,2 \%)$ \\
\hline & DMo (2) & $03(11,5 \%)$ & $05(19,2 \%)$ & $07(27,0 \%)$ & 00 & $15(57,6 \%)$ \\
\hline & (3) & 00 & $04(15,3 \%)$ & $01(3,8 \%)$ & $01(3,8 \%)$ & $06(23,0 \%)$ \\
\hline & TOTAL & $06(23,0 \%)$ & $10(38,4 \%)$ & $09(34,5 \%)$ & $01(3,8 \%)$ & 26 \\
\hline
\end{tabular}

\section{GRUPO 3: SOLUÇÃO EXPERIMENTAL 2 (SONDA)}

TABELA 38 - Variação da sensibilidade dentinária no Grupo 3 (Solução Experimental 2) utilizando-se a sonda como estímulo, comparando-se os resultados obtidos antes e depois da primeira aplicação.

\begin{tabular}{|c|c|c|c|c|c|c|}
\hline \multirow{2}{*}{\multicolumn{2}{|c|}{$\begin{array}{l}\text { SOL. EXP. } 2 \\
\text { SONDA }\end{array}$}} & \multicolumn{5}{|c|}{ DEPOIS DA $1^{a}$ APLICAÇÃO } \\
\hline & & \multirow{2}{*}{$\begin{array}{ll}\text { DA } & (0) \\
00 & \end{array}$} & \multirow{2}{*}{$\begin{array}{ll}\text { DMi } & (1) \\
00 & \end{array}$} & \multirow{2}{*}{$\begin{array}{l}\text { DMo (2) } \\
00\end{array}$} & \multirow{2}{*}{$\begin{array}{ll}\mathrm{DI} & \text { (3) } \\
00 & \end{array}$} & \multirow{2}{*}{$\begin{array}{l}\text { TOTAL } \\
00\end{array}$} \\
\hline ANTES & DA & & & & & \\
\hline DA & DMi (1) & $01(4,1 \%)$ & $04(16,6 \%)$ & $01(4,1 \%)$ & 00 & $06(25,0 \%)$ \\
\hline $1^{a}$ & DMo (2) & $01(4,1 \%)$ & $06(25,0 \%)$ & $05(20,8 \%)$ & $01(4,1 \%)$ & $13(54,1 \%)$ \\
\hline \multirow[t]{2}{*}{ APLIC. } & (3) & 00 & 00 & $03(12,5 \%)$ & $02(8,3 \%)$ & $05(20,9 \%)$ \\
\hline & TOTAL & $02(8,3 \%)$ & $10(41,6 \%)$ & $09(38 \%)$ & $03(12 \%)$ & 24 \\
\hline
\end{tabular}


TABELA 39 - Variação da sensibilidade dentinária no Grupo 3 (Solução Experimental 2) utilizando-se a sonda como estímulo, comparando-se os resultados obtidos antes da primeira aplicação e depois da segunda aplicação.

\begin{tabular}{|c|c|c|c|c|c|c|}
\hline \multirow{2}{*}{\multicolumn{2}{|c|}{$\begin{array}{c}\text { SOL. EXP. } 2 \\
\text { SONDA }\end{array}$}} & \multicolumn{5}{|c|}{ DEPOIS DA $2^{\mathrm{a}}$ APLICAÇÃO } \\
\hline & & \multirow{2}{*}{$\begin{array}{ll}\text { DA } & (0) \\
00 & \end{array}$} & \multirow{2}{*}{$\begin{array}{l}\mathrm{DMi} \quad(1) \\
00\end{array}$} & \multirow{2}{*}{$\begin{array}{ll}\text { DMo } & \text { (2) } \\
00\end{array}$} & \multirow{2}{*}{$\begin{array}{ll}\mathrm{DI} & (3) \\
00 & \end{array}$} & \multirow{2}{*}{$\begin{array}{l}\text { TOTAL } \\
00\end{array}$} \\
\hline ANTES & DA $\quad(0)$ & & & & & \\
\hline DA & DMi (1) & $02(8,3 \%)$ & $03(12,5 \%)$ & $01(4,1 \%)$ & 00 & $06(25,0 \%)$ \\
\hline $1^{a}$ & DMo (2) & $02(8,3 \%)$ & $05(20,8 \%)$ & $06(25,0 \%)$ & 00 & $13(54,1 \%)$ \\
\hline \multirow[t]{2}{*}{ APLIC. } & (3) & $01(4,1 \%)$ & $02(8,3 \%)$ & $02(8,3 \%)$ & 00 & $05(20,9 \%)$ \\
\hline & TOTAL & $05(21 \%)$ & $10(42 \%)$ & $09(37 \%)$ & 00 & 24 \\
\hline
\end{tabular}

TABELA 40 - Variação da sensibilidade dentinária no Grupo 3 (Solução Experimental 2) utilizando-se a sonda como estímulo, comparando-se os resultados obtidos antes da primeira aplicação e depois da terceira aplicação.

\begin{tabular}{|c|c|c|c|c|c|c|}
\hline \multirow{2}{*}{\multicolumn{2}{|c|}{$\begin{array}{c}\text { SOL. EXP. } 2 \\
\text { SONDA }\end{array}$}} & \multicolumn{5}{|c|}{ DEPOIS DA $3^{\mathrm{a}}$ APLICAÇÃO } \\
\hline & & $\begin{array}{ll}D A & (0)\end{array}$ & DMi (1) & DMo (2) & DI $\quad$ (3) & TOTAL \\
\hline \multirow{5}{*}{$\begin{array}{l}\text { ANTES } \\
\text { DA } \\
1^{\text {a }} \\
\text { APLIC. }\end{array}$} & $\begin{array}{ll}\text { DA } & (0)\end{array}$ & 00 & 00 & 00 & 00 & 00 \\
\hline & DMi (1) & $03(12,5 \%)$ & $03(12,5 \%)$ & 00 & 00 & $06(25,0 \%)$ \\
\hline & DMo (2) & $06(25,0 \%)$ & $03(12,5 \%)$ & $04(16,6 \%)$ & 00 & $13(54,1 \%)$ \\
\hline & (3) & 00 & $03(12,5 \%)$ & $02(8,3 \%)$ & 00 & $05(20,9 \%)$ \\
\hline & TOTAL & $09(37,5 \%)$ & $09(37,5 \%)$ & $06(25 \%)$ & 00 & 24 \\
\hline
\end{tabular}




\section{GRUPO 3: SOLUÇÃO EXPERIMENTAL 2 (AR)}

TABELA 41 - Variação da sensibilidade dentinária no Grupo 3 (Solução Experimental 2) utilizando-se o ar como estímulo, comparando-se os resultados obtidos antes e depois da primeira aplicação.

\begin{tabular}{|c|c|c|c|c|c|c|}
\hline \multirow{2}{*}{\multicolumn{2}{|c|}{$\begin{array}{c}\text { SOL. EXP. } 2 \\
\text { AR }\end{array}$}} & \multicolumn{5}{|c|}{ DEPOIS DA $1^{\text {a }}$ APLICAÇÃO } \\
\hline & & \multirow{2}{*}{$\begin{array}{ll}\text { DA } & (0) \\
00 & \end{array}$} & \multirow{2}{*}{$\begin{array}{ll}\text { DMi } \quad(1) \\
00\end{array}$} & \multirow{2}{*}{$\begin{array}{l}\text { DMo (2) } \\
00\end{array}$} & \multirow{2}{*}{$\begin{array}{ll}\mathrm{DI} & (3) \\
00 & \end{array}$} & \multirow{2}{*}{$\begin{array}{l}\text { TOTAL } \\
00\end{array}$} \\
\hline ANTES & $\mathrm{DA}$ & & & & & \\
\hline DA & DMi (1) & $01(3,7 \%)$ & $02(7,4 \%)$ & $01(3,7 \%)$ & $02(7,4 \%)$ & $06(22,2 \%)$ \\
\hline $1^{a}$ & DMo (2) & 00 & $03(11,1 \%)$ & $08(29,6 \%)$ & $01(3,7 \%)$ & $12(44,4 \%)$ \\
\hline \multirow[t]{2}{*}{ APLIC. } & (3) & 00 & 00 & $03(11,1 \%)$ & $06(22,2 \%)$ & $09(33,3 \%)$ \\
\hline & TOTAL & $01(3,7 \%)$ & $05(18,5 \%)$ & $12(44,5 \%)$ & $09(33,5 \%)$ & 27 \\
\hline
\end{tabular}

TABELA 42 - Variação da sensibilidade dentinária no Grupo 3 (Solução Experimental 2) utilizando-se o ar como estímulo, comparando-se os resultados obtidos antes da primeira aplicação e depois da segunda aplicação.

\begin{tabular}{|c|c|c|c|c|c|c|}
\hline \multirow{2}{*}{\multicolumn{2}{|c|}{$\begin{array}{c}\text { SOL. EXP. } 2 \\
\text { AR }\end{array}$}} & \multicolumn{5}{|c|}{ DEPOIS DA $2^{\mathrm{a}}$ APLICAÇÃO } \\
\hline & & \multirow{2}{*}{$\begin{array}{ll}\text { DA } & (0) \\
00 & \end{array}$} & \multirow{2}{*}{\begin{tabular}{|ll}
$\mathrm{DMi}$ & $(1)$ \\
00 &
\end{tabular}} & \multirow{2}{*}{$\begin{array}{ll}\text { DMo (2) } \\
00\end{array}$} & \multirow{2}{*}{$\begin{array}{ll}\text { DI } & (3) \\
00 & \end{array}$} & \multirow{2}{*}{$\begin{array}{l}\text { TOTAL } \\
00\end{array}$} \\
\hline ANTES & DA $(0)$ & & & & & \\
\hline DA & DMi (1) & $01(3,7 \%)$ & $04(14,8 \%)$ & 00 & $01(3,7 \%)$ & $06(22,2 \%)$ \\
\hline $1^{\mathrm{a}}$ & DMo (2) & $02(7,4 \%)$ & $06(22,2 \%)$ & $04(14,8 \%)$ & 00 & $12(44,4 \%)$ \\
\hline \multirow[t]{2}{*}{ APLIC. } & (3) & $01(3,7 \%)$ & $03(11,1 \%)$ & $03(11,1 \%)$ & $02(7,4 \%)$ & $09(33,3 \%)$ \\
\hline & TOTAL & $04(15 \%)$ & $13(48 \%)$ & $07(26 \%)$ & $03(11,1 \%)$ & 27 \\
\hline
\end{tabular}


TABELA 43 - Variação da sensibilidade dentinária no Grupo 3 (Solução Experimental 2) utilizando-se o ar como estímulo, comparando-se os resultados obtidos antes da primeira aplicação e depois da terceira aplicação.

\begin{tabular}{|c|c|c|c|c|c|c|}
\hline \multirow{2}{*}{\multicolumn{2}{|c|}{$\begin{array}{c}\text { SOL. EXP. } 2 \\
\text { AR }\end{array}$}} & \multicolumn{5}{|c|}{ DEPOIS DA $3^{\mathrm{a}}$ APLICAÇÃO } \\
\hline & & DA $(0)$ & $\mathrm{DMi} \quad(1)$ & DMo (2) & $\begin{array}{ll}\mathrm{DI} & (3)\end{array}$ & TOTAL \\
\hline \multirow{5}{*}{$\begin{array}{l}\text { ANTES } \\
\text { DA } \\
1^{\text {a }} \\
\text { APLIC. }\end{array}$} & $\mathrm{DA} \quad(0)$ & 00 & 00 & 00 & 00 & 00 \\
\hline & DMi (1) & $01(3,7 \%)$ & $04(14,8 \%)$ & $01(3,7 \%)$ & 00 & $06(22,2 \%)$ \\
\hline & DMo (2) & $02(7,4 \%)$ & $07(25,9 \%)$ & $03(11,1 \%)$ & 00 & $12(44,4 \%)$ \\
\hline & (3) & $02(7,4 \%)$ & $03(11,1 \%)$ & $04(14,8 \%)$ & 00 & $09(33,3 \%)$ \\
\hline & TOTAL & $05(18,5 \%)$ & $14(51,8 \%)$ & $08(29,5 \%)$ & 00 & 27 \\
\hline
\end{tabular}

\section{GRUPO 4: PLACEBO (SONDA)}

TABELA 44 - Variação da sensibilidade dentinária no Grupo 4 (Placebo) utilizando-se a sonda como estímulo, comparando-se os resultados obtidos antes e depois da primeira aplicação.

\begin{tabular}{|c|c|c|c|c|c|c|}
\hline \multirow{2}{*}{\multicolumn{2}{|c|}{$\begin{array}{c}\text { PLACEBO } \\
\text { SONDA }\end{array}$}} & \multicolumn{5}{|c|}{ DEPOIS DA $1^{\text {a }}$ APLICAÇÃO } \\
\hline & & DA $(0)$ & DMi (1) & DMo (2) & DI (3) & TOTAL \\
\hline \multirow{5}{*}{$\begin{array}{l}\text { ANTES } \\
\text { DA } \\
1^{\mathrm{a}} \\
\text { APLIC. }\end{array}$} & $\begin{array}{ll}\text { DA } & (0)\end{array}$ & 00 & 00 & 00 & 00 & 00 \\
\hline & DMi (1) & $01(7,1 \%)$ & $02(14,2 \%)$ & $02(14,2 \%)$ & $01(7,1 \%)$ & $06(42,8 \%)$ \\
\hline & DMo (2) & $01(7,1 \%)$ & $03(21,4 \%)$ & $02(14,2 \%)$ & 00 & $06(42,8 \%)$ \\
\hline & (3) & 00 & 00 & 00 & $02(14,2 \%)$ & $02(14,3 \%)$ \\
\hline & TOTAL & $02(14,2 \%)$ & $05(35,7 \%)$ & $04(28,5 \%)$ & $03(21,5 \%)$ & 14 \\
\hline
\end{tabular}


TABELA 45 - Variação da sensibilidade dentinária no Grupo 4 (Placebo) utilizando-se a sonda como estímulo, comparando-se os resultados obtidos antes da primeira aplicação e depois da segunda aplicação.

\begin{tabular}{|c|c|c|c|c|c|c|}
\hline \multirow{2}{*}{\multicolumn{2}{|c|}{$\begin{array}{c}\text { PLACEBO } \\
\text { SONDA }\end{array}$}} & \multicolumn{5}{|c|}{ DEPOIS DA $2^{\mathrm{a}}$ APLICAÇÃO } \\
\hline & & DA (0) & DMi (1) & DMo (2) & DI (3) & TOTAL \\
\hline \multirow{5}{*}{$\begin{array}{l}\text { ANTES } \\
\text { DA } \\
1^{\mathrm{a}} \\
\text { APLIC. }\end{array}$} & DA $(0)$ & 00 & 00 & 00 & 00 & 00 \\
\hline & DMi (1) & $03(21,4 \%)$ & $02(14,2 \%)$ & 00 & $01(7,1 \%)$ & $06(42,8 \%)$ \\
\hline & DMo (2) & $01(7,1 \%)$ & $03(21,4 \%)$ & $02(14,2 \%)$ & 00 & $06(42,8 \%)$ \\
\hline & (3) & 00 & $01(7,1 \%)$ & 00 & $01(7,1 \%)$ & $02(14,3 \%)$ \\
\hline & TOTAL & $04(28,5 \%)$ & $06(42,8 \%)$ & $02(14,2 \%)$ & $02(14,2 \%)$ & 14 \\
\hline
\end{tabular}

TABELA 46 - Variação da sensibilidade dentinária no Grupo 4 (Placebo) utilizando-se a sonda como estímulo, comparando-se os resultados obtidos antes da primeira aplicação e depois da terceira aplicação.

\begin{tabular}{|c|c|c|c|c|c|c|}
\hline \multirow{2}{*}{\multicolumn{2}{|c|}{$\begin{array}{c}\text { PLACEBO } \\
\text { SONDA }\end{array}$}} & \multicolumn{5}{|c|}{ DEPOIS DA $3^{\mathrm{a}}$ APLICAÇÃO } \\
\hline & & $\begin{array}{ll}\text { DA } & (0)\end{array}$ & $\begin{array}{|ll|}\text { DMi } & \text { (1) }\end{array}$ & DMo (2) & DI $\quad$ (3) & TOTAL \\
\hline \multirow{5}{*}{$\begin{array}{l}\text { ANTES } \\
\text { DA } \\
1^{\mathrm{a}} \\
\text { APLIC. }\end{array}$} & DA $(0)$ & 00 & 00 & 00 & 00 & 00 \\
\hline & DMi (1) & $02(14,2 \%)$ & $04(28,5 \%)$ & 00 & 00 & $06(42,8 \%)$ \\
\hline & DMo (2) & $01(7,1 \%)$ & $04(28,5 \%)$ & $01(7,1 \%)$ & 00 & $06(42,8 \%)$ \\
\hline & (3) & 00 & $01(7,1 \%)$ & 00 & $01(7,1 \%)$ & $02(14,3 \%)$ \\
\hline & TOTAL & $03(21,4 \%)$ & 09 (64,2\%) & $01(7 \%)$ & $01(7,1 \%)$ & 14 \\
\hline
\end{tabular}




\section{GRUPO 4: PLACEBO (AR)}

TABELA 47 - Variação da sensibilidade dentinária no Grupo 4 (Placebo) utilizando-se o ar como estímulo, comparando-se os resultados obtidos antes e depois da primeira aplicação.

\begin{tabular}{|c|c|c|c|c|c|c|}
\hline \multirow{2}{*}{\multicolumn{2}{|c|}{$\begin{array}{c}\text { PLACEBO } \\
\text { AR }\end{array}$}} & \multicolumn{5}{|c|}{ DEPOIS DA $1^{\text {a }}$ APLICAÇÃO } \\
\hline & & $\begin{array}{ll}\text { DA } & (0)\end{array}$ & $\begin{array}{ll}\mathrm{DMi} & (1)\end{array}$ & DMo (2) & DI (3) & TOTAL \\
\hline \multirow{5}{*}{$\begin{array}{l}\text { ANTES } \\
\text { DA } \\
1^{A} \mathrm{a} \\
\text { APLIC. }\end{array}$} & $\begin{array}{ll}\text { DA } & (0)\end{array}$ & 00 & 00 & 00 & 00 & 00 \\
\hline & DMi (1) & $02(11,7 \%)$ & 00 & $01(5,8 \%)$ & 00 & $03(17,6 \%)$ \\
\hline & DMo (2) & 00 & $05(29,4 \%)$ & $04(23,5 \%)$ & 00 & $09(53,0 \%)$ \\
\hline & (3) & 00 & $01(5,8 \%)$ & $02(11,7 \%)$ & $02(11,7 \%)$ & $05(29,4 \%)$ \\
\hline & TOTAL & $02(11,7 \%)$ & $06(35,2 \%)$ & $07(41,1 \%)$ & $02(11,7 \%)$ & 17 \\
\hline
\end{tabular}

TABELA 48 - Variação da sensibilidade dentinária no Grupo 4 (Placebo) utilizando-se o ar como estímulo, comparando-se os resultados obtidos antes da primeira aplicação e depois da segunda aplicação.

\begin{tabular}{|c|c|c|c|c|c|c|}
\hline \multirow{2}{*}{\multicolumn{2}{|c|}{$\begin{array}{c}\text { PLACEBO } \\
\text { AR }\end{array}$}} & \multicolumn{5}{|c|}{ DEPOIS DA $2^{\mathrm{a}}$ APLICAÇÃO } \\
\hline & & DA $(0)$ & $\mathrm{DMi} \quad(1)$ & DMo (2) & DI (3) & TOTAL \\
\hline \multirow{5}{*}{$\begin{array}{l}\text { ANTES } \\
\text { DA } \\
1^{A} \mathrm{a} \\
\text { APLIC. }\end{array}$} & $\begin{array}{ll}\text { DA } & (0)\end{array}$ & 00 & 00 & 00 & 00 & 00 \\
\hline & DMi (1) & $02(11,7 \%)$ & $01(5,8 \%)$ & 00 & 00 & $03(17,6 \%)$ \\
\hline & DMo (2) & $02(11,7 \%)$ & $05(29,4 \%)$ & $02(11,7 \%)$ & 00 & $09(53,0 \%)$ \\
\hline & (3) & 00 & $01(5,8 \%)$ & $04(23,5 \%)$ & 00 & $05(29,4 \%)$ \\
\hline & TOTAL & $04(23,5 \%)$ & $07(41,1 \%)$ & $06(35,2 \%)$ & 00 & 17 \\
\hline
\end{tabular}


TABELA 49 - Variação da sensibilidade dentinária no Grupo 4 (Placebo) utilizando-se o ar como estímulo, comparando-se os resultados obtidos antes da primeira aplicação e depois da terceira aplicação.

\begin{tabular}{|c|c|c|c|c|c|c|}
\hline \multirow{2}{*}{\multicolumn{2}{|c|}{$\begin{array}{c}\text { PLACEBO } \\
\text { AR }\end{array}$}} & \multicolumn{5}{|c|}{ DEPOIS DA $3^{\mathrm{a}}$ APLICAÇÃO } \\
\hline & & DA (0) & DMi (1) & DMo (2) & DI (3) & TOTAL \\
\hline \multirow{5}{*}{$\begin{array}{l}\text { ANTES } \\
\text { DA } \\
1^{\mathrm{a}} \\
\text { APLIC. }\end{array}$} & $\begin{array}{ll}\text { DA } & (0)\end{array}$ & 00 & 00 & 00 & 00 & 00 \\
\hline & DMi (1) & $02(11,7 \%)$ & $01(5,8 \%)$ & 00 & 00 & $03(17,6 \%)$ \\
\hline & DMo (2) & $04(23,5 \%)$ & $04(23,5 \%)$ & $01(5,8 \%)$ & 00 & $09(53,0 \%)$ \\
\hline & (3) & $01(5,8 \%)$ & $02(11,7 \%)$ & $02(11,7 \%)$ & 00 & $05(29,4 \%)$ \\
\hline & TOTAL & $07(41,1 \%)$ & $07(41,1 \%)$ & $03(17,6 \%)$ & 00 & 17 \\
\hline
\end{tabular}

Para uma análise dos resultados de cada grupo, independente do estímulo utilizado, seguem-se as seguintes tabelas:

TABELA 50 - Variação da sensibilidade dentinária no Grupo 1, independente do estímulo utilizado, comparando-se os resultados obtidos antes da primeira aplicação e depois da quarta aplicação.

\begin{tabular}{|c|c|c|c|c|c|c|}
\hline \multirow{2}{*}{\multicolumn{2}{|c|}{$\begin{array}{c}\text { G1 } \\
\text { SONDA / AR }\end{array}$}} & \multicolumn{5}{|c|}{ DEPOIS DA $4^{\mathrm{a}}$ APLICAÇÃO } \\
\hline & & \multirow{2}{*}{$\begin{array}{|ll|}\text { DA } & (0) \\
00 & \\
\end{array}$} & \multirow{2}{*}{$\begin{array}{ll}\text { DMi } & (1) \\
00\end{array}$} & \multirow{2}{*}{$\begin{array}{l}\text { DMo (2) } \\
00\end{array}$} & \multirow{2}{*}{$\begin{array}{ll}\mathrm{DI} & (3) \\
00 & \end{array}$} & \multirow{2}{*}{$\begin{array}{l}\text { TOTAL } \\
00\end{array}$} \\
\hline ANTES & DA (0) & & & & & \\
\hline DA & $\mathrm{DMi}(1)$ & $02(8,7 \%)$ & 00 & 00 & 00 & $02(8,7 \%)$ \\
\hline $1^{a}$ & DMo (2) & $07(30,4 \%)$ & $05(21,7 \%)$ & 00 & 00 & $12(52,2 \%)$ \\
\hline \multirow[t]{2}{*}{ APLIC. } & (3) & $02(8,7 \%)$ & $06(26,0 \%)$ & $01(4,3 \%)$ & 00 & $09(39,1 \%)$ \\
\hline & TOTAL & $11(47,8 \%)$ & $11(47,8 \%)$ & $01(4,3 \%)$ & 00 & 23 \\
\hline
\end{tabular}


Pode-se observar que, antes da primeira aplicação (baseline), a maior concentração de dentes com hiperestesia dentinária estava em dor moderada $(12: 52,1 \%)$ e intensa $(9: 39,1 \%)$, havendo apenas 02 dentes (8,7\%) com dor mínima. Após o tratamento com o Oxa-Gel ${ }^{\circledR}$, independente do estímulo utilizado, houve um aumento na concentração de dentes com dor ausente (11:47,8\%) e mínima (11:47,8\%), uma diminuição da concentração de dentes com dor moderada $(1: 4,3 \%)$, e nenhum dente com dor intensa.

TABELA 51 - Variação da sensibilidade dentinária no Grupo 1, independente do estímulo utilizado, comparando-se os resultados obtidos depois da quarta aplicação e depois de 06 meses.

\begin{tabular}{|c|c|c|c|c|c|c|}
\hline \multirow{2}{*}{\multicolumn{2}{|c|}{$\begin{array}{c}\text { G1 } \\
\text { SONDA / AR }\end{array}$}} & \multicolumn{5}{|c|}{ DEPOIS DE 06 MESES } \\
\hline & & \multirow{2}{*}{$\begin{array}{l}\mathrm{DA}(0) \\
06(33,3 \%)\end{array}$} & \multirow{2}{*}{$\begin{array}{l}\text { DMi (1) } \\
01(5,5 \%)\end{array}$} & \multirow{2}{*}{$\begin{array}{l}\text { DMo (2) } \\
03(16,6 \%)\end{array}$} & \multirow{2}{*}{$\begin{array}{ll}\mathrm{DI} & (3) \\
00 & \end{array}$} & \multirow{2}{*}{$\begin{array}{l}\text { TOTAL } \\
10(55,5 \%)\end{array}$} \\
\hline DEPOIS & $\mathrm{DA} \quad(0)$ & & & & & \\
\hline DA & DMi (1) & $01(5,5 \%)$ & $04(22,2 \%)$ & $02(11,1 \%)$ & $01(5,5 \%)$ & $08(44,4 \%)$ \\
\hline $4^{a}$ & DMo (2) & 00 & 00 & 00 & 00 & 00 \\
\hline \multirow[t]{2}{*}{ APLIC. } & (3) & 00 & 00 & 00 & 00 & 00 \\
\hline & TOTAL & $07(38,8 \%)$ & $05(27,7 \%)$ & $05(27,7 \%)$ & $01(5,5 \%)$ & 18 \\
\hline
\end{tabular}

OBS: O total de dentes da amostra diminuiu porque nem todos os pacientes retornaram para a avaliação de 06 meses.

Decorridos 6 meses foram reavaliados 18 dentes. Pode-se observar que, em comparação com os valores obtidos depois da $4^{\mathrm{a}}$ aplicação, onde a maior concentração era de dentes com dor ausente (10:55,5\%) e mínima $(8: 44,4 \%)$, ocorreu uma diminuição nessa concentração, passando os dentes a apresentarem também dor moderada $(5: 27,5 \%)$ e intensa $(8: 44,4 \%)$. 
TABELA 52 - Variação da sensibilidade dentinária no Grupo 2, independente do estímulo utilizado, comparando-se os resultados obtidos antes da primeira aplicação e depois da quarta aplicação.

\begin{tabular}{|c|c|c|c|c|c|c|}
\hline \multirow{2}{*}{\multicolumn{2}{|c|}{$\begin{array}{c}\text { G2 } \\
\text { SONDA / AR }\end{array}$}} & \multicolumn{5}{|c|}{ DEPOIS DA 4 ${ }^{\mathrm{a}}$ APLICAÇÃO } \\
\hline & & DA (0) & DMi (1) & DMo (2) & DI (3) & TOTAL \\
\hline \multirow{5}{*}{$\begin{array}{l}\text { ANTES } \\
\text { DA } \\
1^{\mathrm{a}} \\
\text { APLIC. }\end{array}$} & DA $(0)$ & 00 & 00 & 00 & 00 & 00 \\
\hline & DMi (1) & $03(11,1 \%)$ & $01(3,7 \%)$ & 00 & 00 & $04(14,8 \%)$ \\
\hline & DMo (2) & $08(29,6 \%)$ & $06(22,2 \%)$ & $01(3,7 \%)$ & 00 & $15(55,6 \%)$ \\
\hline & (3) & $04(14,8 \%)$ & $03(11,1 \%)$ & 00 & $01(3,7 \%)$ & $08(29,6 \%)$ \\
\hline & TOTAL & $15(55,5 \%)$ & $10(37,0 \%)$ & $01(3,7 \%)$ & $01(3,7 \%)$ & 27 \\
\hline
\end{tabular}

No Grupo 2, antes da primeira aplicação, observou-se dentes com dor mínima $(4: 14,8 \%)$, moderada $(15: 55,5 \%)$ e intensa $(8: 29,6 \%)$ e nenhum com dor ausente. Após a $4^{\mathrm{a}}$ aplicação, houve um aumento no número de dentes com dor ausente (15:55,5\%) e mínima (10:37,0\%), e uma diminuição no número de dentes com dor moderada e intensa (1:3,7\% para cada)

TABELA 53 - Variação da sensibilidade dentinária no Grupo 2, independente do estímulo utilizado, comparando-se os resultados obtidos depois da quarta aplicação e depois de 06 meses.

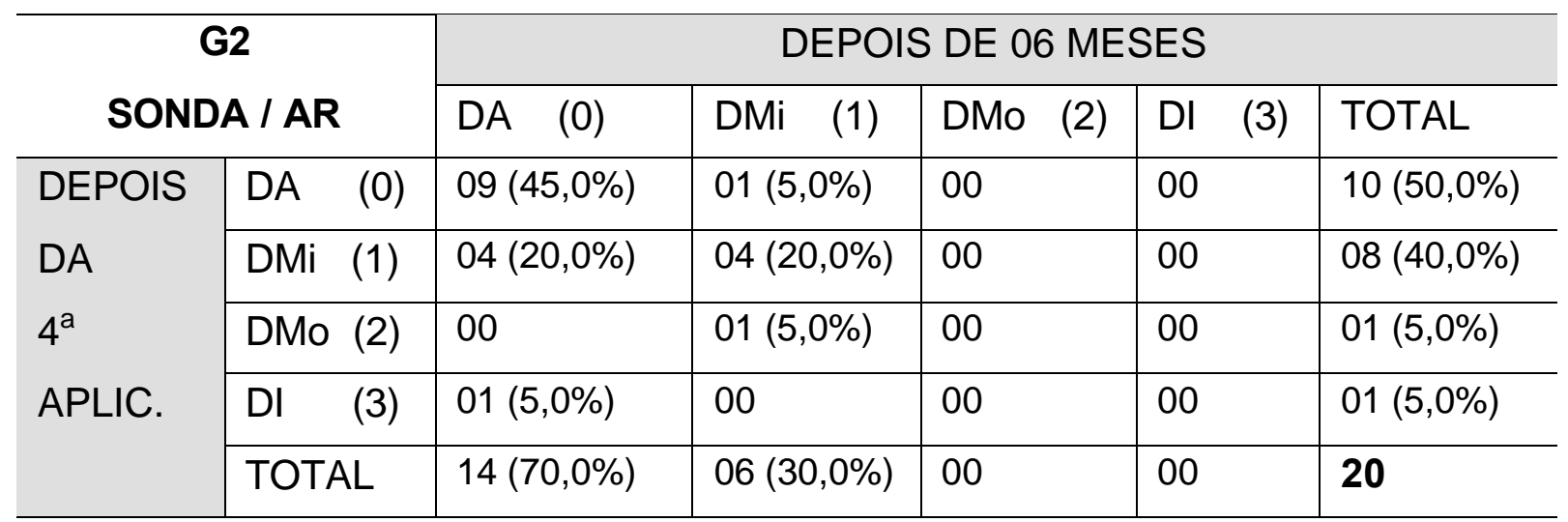

OBS: O total de dentes da amostra diminuiu porque nem todos os pacientes retornaram para a avaliação de 06 meses. 
Nota-se que, após 6 meses, quando 20 dentes foram reavaliados, 14 deles $(70,0 \%)$ passaram a apresentar dor ausente e 6 dentes (30,0\%), dor mínima. Nenhum dos dentes apresentou dor moderada ou intensa.

TABELA 54 - Variação da sensibilidade dentinária no Grupo 3, independente do estímulo utilizado, comparando-se os resultados obtidos antes da primeira aplicação e depois da quarta aplicação.

\begin{tabular}{|c|c|c|c|c|c|c|}
\hline \multirow{2}{*}{\multicolumn{2}{|c|}{$\begin{array}{c}\text { G3 } \\
\text { SONDA / AR }\end{array}$}} & \multicolumn{5}{|c|}{ DEPOIS DA $4^{\mathrm{a}}$ APLICAÇÃO } \\
\hline & & \multirow{2}{*}{$\begin{array}{ll}\text { DA } & (0) \\
00 & \end{array}$} & \multirow{2}{*}{$\begin{array}{ll}\mathrm{DMi} \quad(1) \\
00\end{array}$} & \multirow{2}{*}{$\begin{array}{ll}\text { DMo (2) } \\
00\end{array}$} & \multirow{2}{*}{$\begin{array}{ll}\text { DI } & \text { (3) } \\
00 & \end{array}$} & \multirow{2}{*}{$\begin{array}{l}\text { TOTAL } \\
00\end{array}$} \\
\hline ANTES & $\begin{array}{ll}\text { DA } & (0)\end{array}$ & & & & & \\
\hline DA & DMi (1) & $01(3,7 \%)$ & $02(7,4 \%)$ & 00 & 00 & $03(11,1 \%)$ \\
\hline $1^{a}$ & DMo (2) & $10(37,0 \%)$ & $02(7,4 \%)$ & $02(7,4 \%)$ & 00 & $14(51,9 \%)$ \\
\hline \multirow[t]{2}{*}{ APLIC. } & (3) & $02(7,4 \%)$ & $06(22,2 \%)$ & $02(7,4 \%)$ & 00 & $10(37,0 \%)$ \\
\hline & TOTAL & $13(48,1 \%)$ & $10(37,0 \%)$ & $04(14,8 \%)$ & 00 & 27 \\
\hline
\end{tabular}

Para o Grupo 3, a maior concentração antes da primeira aplicação ocorreu em dentes com dor moderada (14:51,8\%) e intensa $(10: 37,0 \%)$, havendo somente 3 dentes $(11,1 \%)$ com dor mínima. Após as quatro aplicações desse material, observou-se que a maior concentração passou a ser de dentes com dor ausente (13:48,1\%) e mínima (10:37,0\%), havendo somente 4 dentes com dor moderada $(14,8 \%)$ e nenhum com dor intensa.

TABELA 55 - Variação da sensibilidade dentinária no Grupo 3, independente do estímulo utilizado, comparando-se os resultados obtidos depois da quarta aplicação e depois de 06 meses. 


\begin{tabular}{|c|c|c|c|c|c|c|}
\hline \multirow{2}{*}{\multicolumn{2}{|c|}{$\begin{array}{c}\text { G3 } \\
\text { SONDA / AR }\end{array}$}} & \multicolumn{5}{|c|}{ DEPOIS DE 06 MESES } \\
\hline & & \multirow{2}{*}{$\begin{array}{l}\mathrm{DA}(0) \\
04(25,0 \%)\end{array}$} & \multirow{2}{*}{$\frac{\text { DMi }(1)}{02(12,5 \%)}$} & \multirow{2}{*}{$\begin{array}{l}\text { DMo (2) } \\
00\end{array}$} & \multirow{2}{*}{$\begin{array}{l}\text { DI (3) } \\
00\end{array}$} & \multirow{2}{*}{$\frac{\text { TOTAL }}{\text { 06(37,5\%) }}$} \\
\hline DEPOIS & $\mathrm{DA} \quad(0)$ & & & & & \\
\hline DA & DMi (1) & $03(18,7 \%)$ & $01(6,2 \%)$ & $03(18,7 \%)$ & 00 & $07(43,7 \%)$ \\
\hline $4^{a}$ & DMo (2) & $01(6,2 \%)$ & $01(6,2 \%)$ & $01(6,2 \%)$ & 00 & $03(18,7 \%)$ \\
\hline \multirow[t]{2}{*}{ APLIC. } & DI & 00 & 00 & 00 & 00 & 00 \\
\hline & TOTAL & $08(50,0 \%)$ & $04(25,0 \%)$ & $04(25,0 \%)$ & 00 & 16 \\
\hline
\end{tabular}

OBS: O total de dentes da amostra diminuiu porque nem todos os pacientes retornaram para a avaliação de 06 meses.

Através dessa tabela, pode-se observar que, 6 meses após a $4^{a}$ aplicação da Solução Experimental 2, os dentes reavaliados (16) continuaram a apresentar maior concentração de dor ausente (8:50,0\%), mínima (4:25,0\%) e moderada $(4: 25,0 \%)$, não havendo nenhum dente com dor intensa.

TABELA 56 - Variação da sensibilidade dentinária no Grupo 4, independente do estímulo utilizado, comparando-se os resultados obtidos antes da primeira aplicação e depois da quarta aplicação.

\begin{tabular}{|c|c|c|c|c|c|c|}
\hline \multirow{2}{*}{\multicolumn{2}{|c|}{$\begin{array}{c}\text { G4 } \\
\text { SONDA / AR }\end{array}$}} & \multicolumn{5}{|c|}{ DEPOIS DA $4^{a}$ APLICAÇÃO } \\
\hline & & $\mathrm{DA} \quad(0)$ & DMi $\quad(1)$ & DMo (2) & DI (3) & TOTAL \\
\hline \multirow{5}{*}{$\begin{array}{l}\text { ANTES } \\
\text { DA } \\
1^{\mathrm{a}} \\
\text { APLIC. }\end{array}$} & $\begin{array}{ll}\mathrm{DA} & (0)\end{array}$ & 00 & 00 & 00 & 00 & 00 \\
\hline & DMi (1) & $03(17,6 \%)$ & 00 & 00 & 00 & $03(17,6 \%)$ \\
\hline & DMo (2) & $05(29,4 \%)$ & $03(17,6 \%)$ & $01(5,8 \%)$ & 00 & $09(53,0 \%)$ \\
\hline & (3) & $02(11,7 \%)$ & $02(11,7 \%)$ & $01(5,8 \%)$ & 00 & $05(29,4 \%)$ \\
\hline & TOTAL & $10(58,8 \%)$ & $05(29,4 \%)$ & $02(11,7 \%)$ & 00 & 17 \\
\hline
\end{tabular}


Para o Grupo 4 (Placebo), antes da primeira aplicação, os dentes apresentavam uma maior concentração de dor moderada (9:53,0\%) e intensa (5:29,4\%), havendo 3 dentes (17,6\%) com dor mínima. Após a $4^{\text {a }}$ aplicação, mais da metade dos dentes passou a apresentar dor ausente (10:58,8\%), havendo também um aumento do número de dentes com dor mínima (5:29,4\%), e uma diminuição de dentes com dor moderada $(2: 11,7 \%)$.

TABELA 57 - Variação da sensibilidade dentinária no Grupo 4, independente do estímulo utilizado, comparando-se os resultados obtidos depois da quarta aplicação e depois de 06 meses.

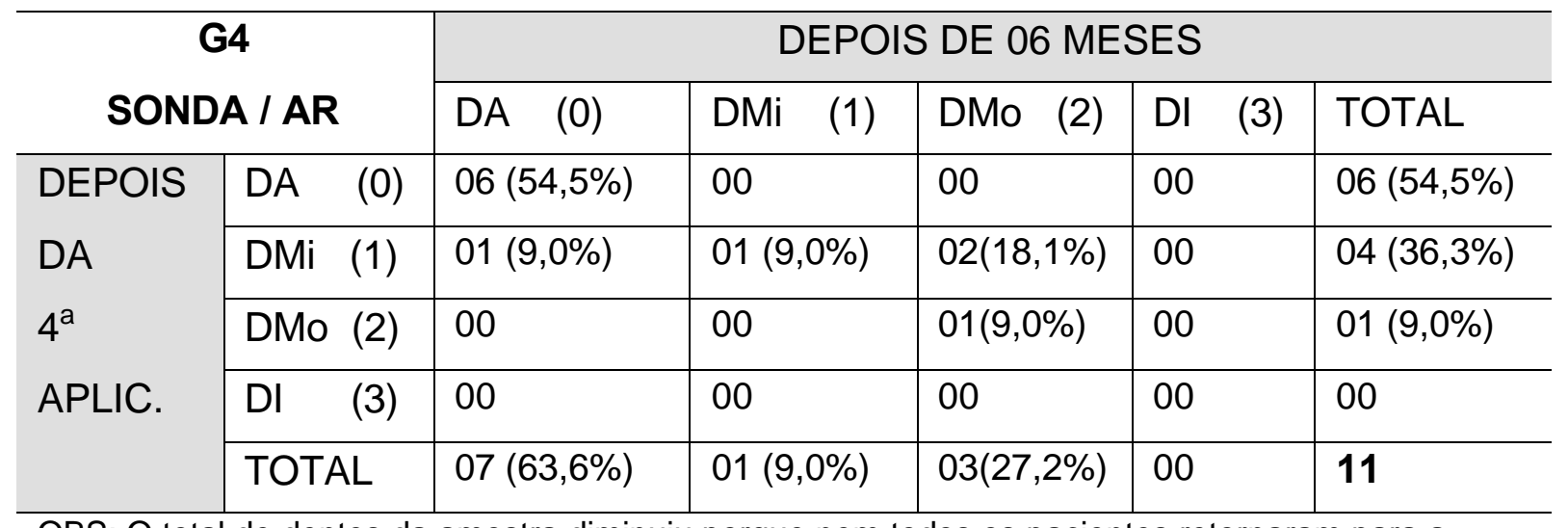

OBS: O total de dentes da amostra diminuiu porque nem todos os pacientes retornaram para a avaliação de 06 meses.

Após 6 meses, 11 dentes foram reavaliados, e pode-se observar um ligeiro aumento do número de dentes com dor ausente $(7: 63,6 \%)$, uma diminuição do número de dentes com dor mínima $(1: 9,0 \%)$ e um aumento de dentes com dor moderada (3:27,2\%). Nenhum dente, porém, apresentou dor intensa. 